\title{
4. SITE 444, SHIKOKU BASIN, DEEP SEA DRILLING PROJECT LEG 58
}

\author{
The Shipboard Scientific Party ${ }^{1}$
}

\section{HOLE 444}

Date occupied: 4 January, 1978

Date departed: 5 January, 1978

Time on hole: 1 day

Position (latitude; longitude): $28^{\circ} 38.25^{\prime} \mathrm{N} ; 137^{\circ} 41.03^{\prime} \mathrm{E}$

Water depth (sea level; corrected $\mathrm{m}$, echo sounding): 4843.0

Water depth (rig floor; corrected $\mathrm{m}$, echo sounding): 4853.0

Bottom felt (m, drill pipe): 4852.0

Penetration (m): 91.5

Number of cores: 10

Total length of cored section $(\mathrm{m}): 91.5$

Total core recovered $(\mathrm{m}): 41.49$

Core recovery $(\%): 45$

Oldest Sediment Cored:

Depth sub-bottom (m): 91.5

Nature: clay and pumice

Age: early Pliocene/late Miocene

Measured velocity $(\mathrm{km} / \mathrm{s}): 1.53$

Basement:

Depth sub-bottom $(\mathrm{m})$ : not reached

Principal Results: Site 444 is in the east-central part of the Shikoku Basin, 45 nautical miles southeast of Site 443 . The stratigraphic section consists of 48 meters of Pleistocene interbedded mud, vitric mud, ash, and clayey nannofossil ooze; 35.5 meters of Pleistocene and Pliocene mud, ash, and vitric

\footnotetext{
${ }^{1}$ George deVries Klein (Co-Chief Scientist), Department of Geology, University of Illinois, Urbana, Illinois; Kazuo Kobayashi (Co-Chief Scientist) Ocean Research Institute, University of Tokyo; Stan M. White, Deep Sea Drilling Project, Scripps Institution of Oceanography, La Jolla, California; Hervé Chamley, Laboratoire de Géologie Marine, Centre d'Océanographie, Centre Universitaire de Luminy, Marseille, France (now at Université de Lille I, Villaneuve d'Ascq, France); Doris Curtis, Bellaire Research Center, Shell Development Company, Houston, Texas; Atsuyuki Mizuno, Geological Survey of Japan, Kawasaki, Japan; Henry Dick, Department of Geology and Geophysics, Woods Hole Oceanographic Institution, Woods Hole, Massachusetts; Gennady V. Nisterenko, Vernadasky Institute of Geochemistry and Analytical Chemistry, USSR Academy of Sciences, Moscow, USSR: Nicholas G. Marsh, Department of Geological Sciences, University of Birmingham, Birmingham, England; Douglas Waples, Chemistry and Geochemistry Department, Colorado School of Mines, Golden, Colorado; Dorothy Jung Echols, Department of Earth and Planetary Sciences, Washington University, St. Louis, Missouri; Hisatake Okada, Department of Geology, Faculty of Science, Yamagata University, Yamagata, Japan; Jon R. Sloan, Department of Geology, University of California, Davis, California; David M. Fountain, Department of Geology, University of Montana, Missoula, Montana; and Hajimu Kinoshita, Department of Earth Sciences, Faculty of Science, Chiba University, Tokyo, Japan.
}

mud; 75.5 meters of Pliocene and late-Miocene mud, ash, vitric mud, nannofossil ooze, radiolarian ooze, quartz sand, and siliceous mud; and 100.6 meters of late- and middle-Miocene mudstone, ash, nannofossil ooze, and radiolarian mudstone, cut by a 10-meter basalt sill. Next below are 19 meters of amygdaloidal phyric basalt flows, and another 19-meter aphanitic, aphyric basalt flow. An early-Pliocene to latestMiocene hiatus occurs in the section. Mixed hemipelagic sediments and ash predominate. Basement age is 15 m.y., which is at variance with the magnetic-anomaly age for the site.

\section{HOLE 444A}

Date occupied: 6 January, 1978

Date departed: 9 January, 1978

Time on holes: $2^{1 / 2}$ days

Position (latitude; longitude): $28^{\circ} 38.25^{\prime} \mathrm{N}$; $137^{\circ} 41.03^{\prime} \mathrm{E}$

Water depth (sea level; corrected $\mathrm{m}$, echo sounding): 4843.0

Water depth (rig floor; corrected $\mathrm{m}$, echo sounding): 4853.0

Bottom felt (m, drill pipe): 4852.0

Penetration (m): 310.0

Number of cores: 27

Total length of cored section (m): 228.0

Total core recovered $(\mathrm{m}): 107.2$

Core recovery $(\%): 47$

Oldest Sediment Cored:

Depth sub-bottom (m): 272.7

Nature: red clay

Age: late early or middle Miocene

Measured velocity $(\mathrm{km} / \mathrm{s}): 1: 72$

Basement:

Depth sub-bottom (m): 310.0

Nature: basalt

Velocity range $(\mathrm{km} / \mathrm{s}): 4.25-5.46$

Principal Results: See Hole 444.

\section{BACKGROUND AND OBJECTIVES}

\section{Background}

The background and objectives for Site 444 are complementary to the background and objectives reviewed for Sites 442 and 443.

Site 444 is in the Shikoku Basin and was chosen for further testing of hypotheses about the origin of marginal basins. The marine geology of the Shikoku Basin was summarized in the site reports for 442 and 443 , as well as by Karig, Ingle, et al. (1975), Tomoda et al. 
(1975), Kobayashi and Isezaki (1976), and Watts and Weissel (1975). The magnetic-anomaly pattern of the Shikoku Basin is linear (Tomoda et al., 1975), and age determinations of these patterns by Watts and Weissel (1975), Kobayashi and Isezaki (1976), and Kobayashi and Nakata (1977) suggested a symmetrical-spreading history for the Shikoku Basin. Spreading originated from a now-extinct center about $28 \mathrm{Ma}$ and ceased about $18 \mathrm{Ma}$. However, drilling results from Site 443 are not consistent with such a model and indicate instead that a single-limb origin of rifting for the Shikoku Basin must be considered.

Basement-age determination was attempted during Leg 31 of the Deep Sea Drilling Project at Site 297 (Karig, Ingle, et al., 1975), but basement was not reached. Drilling at Site 442 permitted identification of basement 18 to $21 \mathrm{~m} . \mathrm{y}$. old, in agreement with location of that site on magnetic anomaly 6 (see Site 442 report). Drilling at Site 443 indicated that the oldest recovered sediment was 14 to $15 \mathrm{~m} . \mathrm{y}$. old. There are reasons, however, to believe that the oldest sediment may not have been recovered, and the basement age may be slightly older (see Site 443 report). Nevertheless, even an age slightly older than the 15-m.y. age determined biostratigraphically is at variance with the supposed age of magnetic anomaly 6A (Watts and Weissel, 1975; Kobayashi and Isezaki, 1976; Kobayashi and Nakata, 1977). Drilling at Site 444 should permit a better understanding of the basement age on the eastern side of the Shikoku Basin and should resolve this problem.

The sediments recovered from Site 443 show some variance with those recovered at Site 442 . At Site 443, resedimented clays and pelagic carbonate ooze were deposited by turbidity currents during the earliest history of basin rifting, followed by a succession of hemipelagic sediments similar to those at Site 442 . The turbidites appear to be derived from the Kinan Seamount chain near the site, whereas the rest of the succession appears to represent a distal zone of a larger clastic wedge which thickens eastward toward the Iwo Jima Ridge. These data from Sites 442 and 443 are at variance with the occurrence of Pliocene turbidites and thick ash layers at Site 297.

The nature of the crust underlying marginal basins is of interest. Several workers demonstrated that the crust underlying marginal basins is oceanic (Fischer, Heezen, et al., 1971; Andrews, Packham, et al., 1975; Ridley et al., 1974), a finding consistent with observations of olivine basalts at Site 443 . Drilling at Site 442 demonstrated, however, that some of these oceanic basalts may lack olivine and are characterized by higher-thannormal vesicularity.

Site 444 was positioned on a moderate, positive magnetic anomaly, identified as anomaly $6 \mathrm{~A}$, on the eastern side of a hypothetical extinct spreading center in the Shikoku Basin. It is also along a depositional, structural, and topographic trend, 50 nautical miles southeast of Site 443. The site was located along a seismicreflection profile surveyed by the R/V Hakuko-Maru (KH-77-1), shown in Figure 1. The seismic-survey line obtained by the D/V Glomar Challenger is shown in Figure 2.

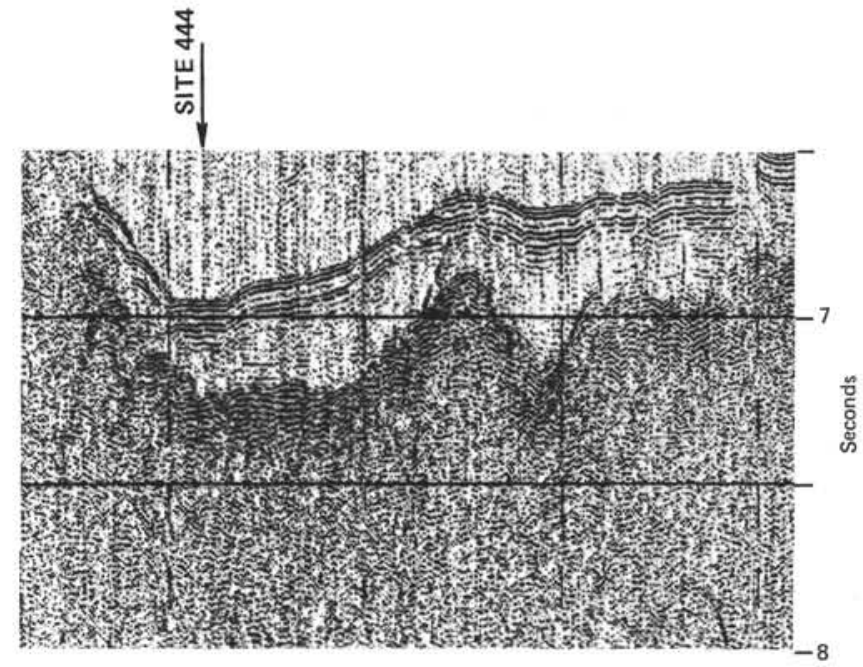

Figure 1. Seismic-survey profile through Shikoku Basin by R/V Hakuko-Maru.

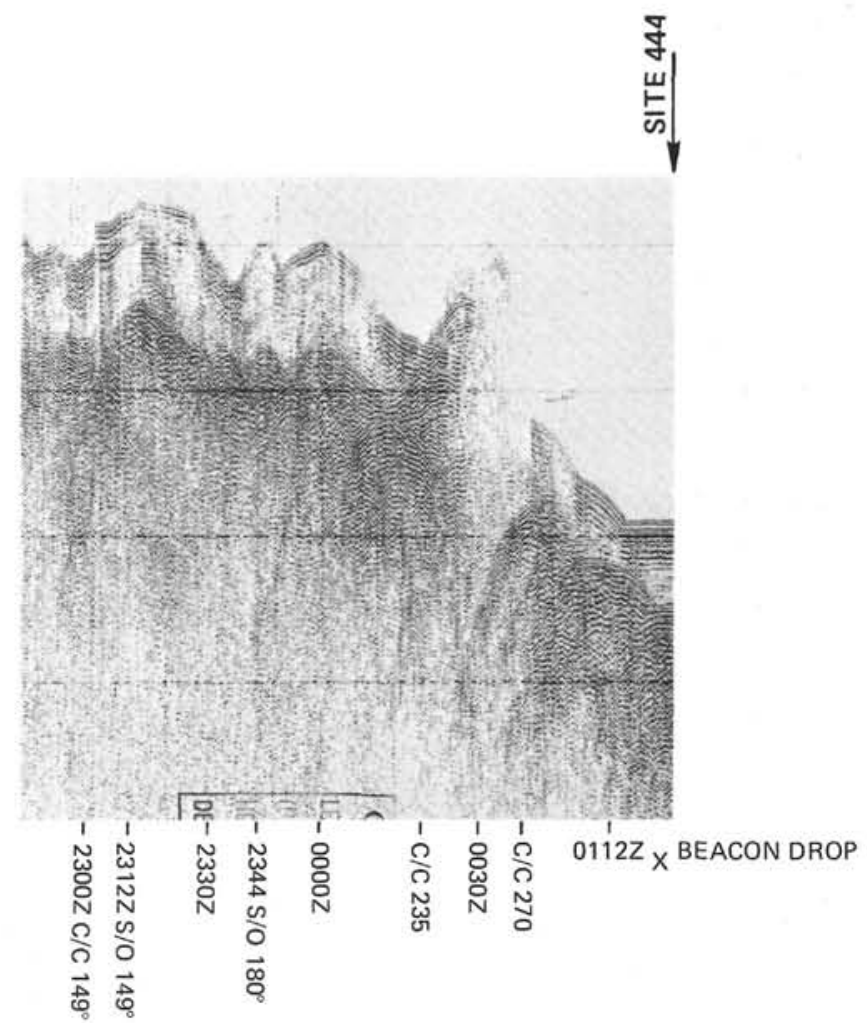

Figure 2. Glomar Challenger seismic-reflection profile approaching Site 444. See Figure 3 for location.

\section{Objectives}

Drilling objectives at Site 444 were threefold. Of prime importance was the paleontological determination of the age of the basalt basement, so as to calibrate the magnetic-anomaly age determinations of earlier study and to test the hypothesis of a symmetricalspreading origin of the Shikoku Basin. A second objective was investigation of the variability of marginalbasin sedimentation sequences and dispersal patterns. 
Prior drilling at Sites 297, 442, and 443 indicated derivation of sediment from Shikoku Island, the KyushuPalau Ridge, the Iwo Jima Ridge, and the Kinan Seamount chain. Are there other sources to consider? What are they? Where are they? How do they control sediment distribution and composition?

A third objective was determination of the mineralogy, petrology, and chemical composition of the basalt floor of the Shikoku Basin and comparison of these data with drilling results at Sites 442 and 443 , as well as other oceanic domains. In addition, paleomagnetic ages of the basalt columnar section were to be determined to understand the crustal evolution of this and other back-arc basins.

\section{OPERATIONS}

The Challenger left Site 443 at 0042 hours and headed on a southeasterly course for proposed Site 444 (Figure 3). At 0700 hours, it was necessary to change the heading to $355^{\circ}$, as it was apparent that the Challenger had overrun the seismic-line location of 444 by 7 miles. A series of course changes were undertaken from 0800 to 0918 hours, and at 0918 hours a heading of $235^{\circ}$ was followed to the site location. A $13.5-\mathrm{kHz}$ beacon was dropped at 1012 hours, 4 January 1978.

Positioning in the auto mode occurred at 1142 hours. Correct PDR depth from the drill floor for Site 444 was 4852 meters.

At 1200 hours RIH started, and the bit and bottomhole assembly were made up. At 2200 hours, Hole 444 was spudded. Ten sedimentary cores were taken, from

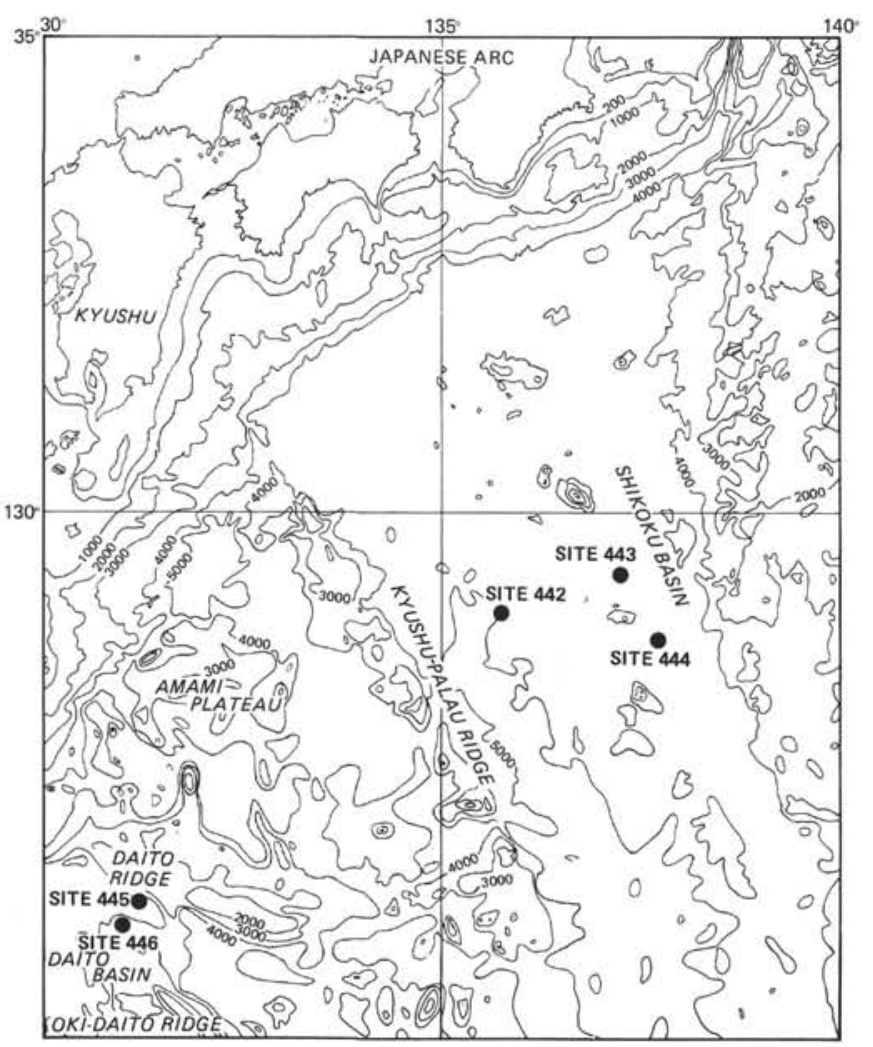

Figure 3. Site location map.
4852.0 to 4943.5 meters (to 91.5 meters sub-bottom), before deteriorating weather required pulling the drill pipe above the mudline in order to wait on weather safely. However, conditions did not improve, and Hole 444 was abandoned at 1143 hours, 5 January 1978. The 10 cores recovered 41.49 meters of sediment (Table 1).

Winds 30 to $40 \mathrm{mph}$, gusting to 50 and $70 \mathrm{mph}$, continued until 0600 hours, 6 January. It had been decided in the meantime to attempt to spud a Hole $444 \mathrm{~A}$ when weather conditions allowed. At 0900 hours, weather conditions allowed positioning in the auto mode, and at 1000 hours RIH began for Hole 444A.

Hole 444A was washed to a depth of 4934 meters ( 82.0 meters sub-bottom) before coring was resumed at 82.0 meters.

Eighteen cores in sediment were taken (Table 1) before recovery of basalt in Core 19. Basalt was cored beginning at 240.6 meters (estimated) sub-bottom. A sharp drop in the drilling rate $(13 \mathrm{~min} / 9.5 \mathrm{~m}$ for Core 20 , versus $205 \mathrm{~min} / 9.5 \mathrm{~m}$ for Core 21 ) indicated penetration of a sediment interbed. Sediment recovery in Cores 21,22 , and 23 was 12.1 meters, basalt recurring in Core 23, at 272.7 meters sub-bottom.

Cores 22 to 27 were taken in basalt on January 8 from sub-bottom depths of 272.0 to 310.0 meters (Table 1), before a rapidly moving low-pressure system forced us to abandon Hole 444A. Accordingly, at 1745 hours, 8 January, POOH started and at 0300 hours, 9 January,

TABLE 1

Site 444 Coring Summary

\begin{tabular}{|c|c|c|c|c|c|c|c|}
\hline \multirow[b]{2}{*}{ Cores } & \multirow{2}{*}{$\begin{array}{l}\text { Date } \\
\text { (Jan., } \\
1978 \text { ) }\end{array}$} & \multirow[b]{2}{*}{ Time } & $\begin{array}{l}\text { Depth From } \\
\text { Drill Floot } \\
\text { (m) }\end{array}$ & \multirow{2}{*}{ 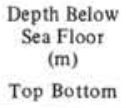 } & \multirow{2}{*}{$\begin{array}{l}\text { Length } \\
\text { Cored } \\
\text { (m) }\end{array}$} & \multirow{2}{*}{$\begin{array}{l}\text { Recovery } \\
\text { (m) }\end{array}$} & \multirow{2}{*}{$\begin{array}{c}\text { Recovery } \\
(\%)\end{array}$} \\
\hline & & & Top Bottom & & & & \\
\hline $444-1$ & 4 & 2308 & $4852.0-4858.0$ & $0.0-6.0$ & 6.0 & 0.20 & 3 \\
\hline 2 & 5 & 0041 & $4858.0-4867.5$ & $6.0-15.5$ & 9.5 & 7.21 & 76 \\
\hline 3 & 5 & 0200 & $4867.5-4877.0$ & $15.5-25.0$ & 9.5 & 4.03 & 42 \\
\hline 4 & 5 & 0319 & $4877.0-4886.5$ & $25.0-34.5$ & 9.5 & 7.34 & 77 \\
\hline 5 & 5 & 0445 & $4886.5-4896.0$ & $34.5-44.0$ & 9.5 & 6.70 & 71 \\
\hline 6 & 5 & 0605 & $4896.0-4905.5$ & $44.0-53.5$ & 9.5 & 1.05 & 11 \\
\hline 7 & 5 & 0725 & $4905.5-4915.0$ & $53.5-63.0$ & 9.5 & 9.54 & 100 \\
\hline 8 & 5 & 0846 & $4915.0-4924.5$ & $63.0-72.5$ & 9.5 & 0.84 & 9 \\
\hline 9 & 5 & 1012 & $4924.5-4934.0$ & $72.5-82.0$ & 9.5 & 1.51 & 16 \\
\hline \multirow[t]{2}{*}{10} & 5 & 1142 & $4934.0-4943.5$ & $82.0-91.5$ & 9.5 & 3.07 & 32 \\
\hline & & & & Totals & 91.5 & 41.49 & 45 \\
\hline $444 \mathrm{~A}-1$ & 6 & 1506 & $4934.0-4943.5$ & $82.0-91.5$ & 9.5 & 8.65 & 91 \\
\hline 2 & 6 & 1631 & $4943.5-4953.0$ & $91.5-101.0$ & 9.5 & 5.00 & 53 \\
\hline 3 & 6 & 1747 & $4953.0-4962.5$ & $101.0-110.5$ & 9.5 & 7.25 & 76 \\
\hline 4 & 6 & 1916 & $4962.5-4972.0$ & $110.5-120.0$ & 9.5 & 1.35 & 14 \\
\hline 5 & 6 & 2044 & $4972.0-4981.5$ & $120.0-129.5$ & 9.5 & 1.83 & 19 \\
\hline 6 & 6 & 2158 & $4981.5-4991.0$ & $129.5-139.0$ & 9.5 & 5.46 & 57 \\
\hline 7 & 6 & 2320 & $4991.0-5000.5$ & $139.0-148.5$ & 9.5 & 1.43 & 15 \\
\hline 8 & 7 & 0048 & $5000.5-5010.0$ & $148.5-158.0$ & 9.5 & 1.36 & 14 \\
\hline 9 & 7 & 0210 & $5010.0-5019.5$ & $158.0-167.5$ & 9.5 & 6.85 & 72 \\
\hline 10 & 7 & 0334 & $5019.5-5029.0$ & $167.5-177.0$ & 9.5 & 1.93 & 20 \\
\hline 11 & 7 & 0450 & $5029.0-5038.5$ & $177.0-186.5$ & 9.5 & 5.43 & 57 \\
\hline 12 & 7 & 0611 & $5038.5-5048.0$ & $186.5-196.0$ & 9.5 & 3.63 & 38 \\
\hline 13 & 7 & 0730 & $5048.0-5057.5$ & $196.0-205.5$ & 9.5 & 3.96 & 42 \\
\hline 14 & 7 & 0845 & $5057.5-5067.0$ & $205.5-215.0$ & 9.5 & 5.08 & 53 \\
\hline 15 & 7 & 1011 & $5067.0-5076.5$ & $215.0-224.5$ & 9.5 & 4.50 & 47 \\
\hline 16 & 7 & 1132 & $5076.5-5082.0$ & $224.5-230.0$ & 5.5 & 4.53 & 82 \\
\hline 17 & 7 & 1251 & $5082.0-5086.0$ & $230.0-234.0$ & 4.0 & 0.33 & 8 \\
\hline 18 & 7 & 1429 & $5086.0-5092.0$ & $234.0-240.0$ & 6.0 & 0.17 & 3 \\
\hline 19 & 7 & 1734 & $5092.0-5095.5$ & $240.0-243.5$ & 3.5 & 0.87 & 25 \\
\hline 20 & 7 & 2240 & $5095.5-5105.0$ & $243.5-253.0$ & 9.5 & 5.22 & 55 \\
\hline 21 & 8 & 0243 & $5105.0-5114.5$ & $253.0-262.5$ & 9.5 & 2.92 & 31 \\
\hline 22 & 8 & 0411 & $5114.5-5124.0$ & $262.5-272.0$ & 9. & & 89 \\
\hline 23 & 8 & 0557 & $5124.0-5130.5$ & $272.0-278.5$ & 6.5 & 1.67 & 26 \\
\hline 24 & 8 & 0806 & $5130.5-5133.5$ & $278.5-281.5$ & 3.0 & 3.00 & 100 \\
\hline 25 & 8 & 1149 & $5133.5-5143.0$ & $281.5-291.0$ & 9.5 & 4.89 & 51 \\
\hline \multirow{3}{*}{$\begin{array}{l}26 \\
27\end{array}$} & 8 & 1426 & $5143.0-5152.5$ & $291.0-300.5$ & 9.5 & 5.12 & 54 \\
\hline & 8 & 1737 & $5152.5-5162.0$ & $300.5-310.0$ & 9.5 & 6.31 & 66 \\
\hline & & & & Totals & 228.0 & 107.2 & 47 \\
\hline
\end{tabular}


all gear was secured. At 0356 hours, the Challenger departed for Site 445.

\section{SEDIMENT LITHOLOGY}

Coring at Site 444 comprised a total of 260.6 meters of sediments and sedimentary rocks of the middle Miocene to Pleistocene, in two holes (444 and 444A). Continuous coring in Hole 444 reached a depth of 91.5 meters (bottom of Core 10). Coring began in Hole 444A at 82.0 meters, the depth of the top of Core 10 in Hole 444 , and continuous coring in sediments reached a depth of 240.6 meters (Core 19), top of the first basalt. The first basalt extended to 253.0 meters (bottom of Core 20). A sediment layer 20 meters thick was cored from 253.0 meters (top of Core 21) to 273.0 meters (in Core 23), where a second basalt layer began. Coring continued in basalt to 310.0 meters.

The sedimentary sequence, divided principally on the basis of color, texture and composition, biogenic components, and sedimentary structures, comprises five lithologic units. Table 2 shows a summary of the age, thickness, and character of these lithologic units. Table 3 is a lithologic summary of components.

\section{Unit 1}

Unit I consists of dark-green to dark-gray to olivebrown mud, ash, and calcareous mud. It includes two sub-units.
Sub-unit Ia consists primarily of mud, ash, and calcareous mud. The mud is dark-greenish-gray to darkgray, with a high clay content, as much as 15 per cent glass and a variable content of calcareous nannofossils. Calcareous nannofossils generally are not abundant, but may form as much as 15 per cent of calcareous, olive-brown mud, except for very rare laminated lightgray pelagic nannofossil ooze. Ash is gray, occurring in distinct beds with glass content up to 97 per cent or as ash of varying percentages in muds.

Sub-unit $\mathrm{Ib}$ consists predominantly of calcareous mud, vitric mud, and ash. Sub-unit Ib has more ash and more calcareous nannofossils than Sub-unit Ia, and is distinguished from Sub-unit Ia by its generally brown colors. The calcareous mud, which is mottled olivebrown, pale-brown, dark-grayish-brown, and darkgray, may contain more than 20 per cent nannofossils. Vitric mud, which is mottled olive, pale-brown, and olive-gray, contains up to 20 per cent volcanic glass. Ash, which is olive-gray to light-gray, infrequently occurs as thin $(<2 \mathrm{~cm})$ beds (glass content up to $95 \%)$ irregularly alternating with calcareous mud.

\section{Unit II}

Unit II is distinguished from unit I by a much greater frequency of ash zones and lighter color. This unit consists predominantly of vitric mud and ash. In rare cases, calcareous mud may have a nannofossil content over 50

TABLE 2

Lithologic Units at Site 444

\begin{tabular}{|c|c|c|c|c|c|c|c|}
\hline $\begin{array}{l}\text { Lithologic } \\
\text { Unit }\end{array}$ & Age & Cores & $\begin{array}{l}\text { Depth } \\
(\mathrm{m})\end{array}$ & $\begin{array}{l}\text { Thickness } \\
\text { (m) }\end{array}$ & $\begin{array}{l}\text { Total } \\
\text { Thickness } \\
\text { of Unit } \\
\text { (m) }\end{array}$ & Dominant Color & Dominant Lithology \\
\hline Ia & Pleistocene & $444-4-3,60 \mathrm{~cm}$ & $0-28.6$ & 28.6 & & $\begin{array}{l}\text { Dark greenish gray, } \\
\text { gray, dark gray }\end{array}$ & Mud, vitric mud \\
\hline $\mathrm{Ib}$ & $\begin{array}{l}\text { Pleistocene, } \\
\text { Pliocene }\end{array}$ & $444-4-3,61 \mathrm{~cm}$ to $444-6-1$ & $\begin{array}{l}28.6-48 \\
\text { (est.) }\end{array}$ & 19.4 & 48 & $\begin{array}{l}\text { Olive, olive gray, } \\
\text { pale brown }\end{array}$ & $\begin{array}{l}\text { Vitric mud, mud, } \\
\text { calcareous mud }\end{array}$ \\
\hline II & $\begin{array}{l}\text { Pliocene, } \\
\text { late Miocene }\end{array}$ & $444-6-1$ to $444-10-1,444 \mathrm{~A}-1-1$ & $48-83.5$ & 35.5 & 35.5 & $\begin{array}{l}\text { Light olive brown, } \\
\text { grayish brown }\end{array}$ & Mud, vitric mud \\
\hline IIIa & $\begin{array}{l}\text { Pliocene, } \\
\text { late Miocene }\end{array}$ & $444 A-1-2$ to $444 A-4, C C$ & $83.5-120$ & 36.5 & & $\begin{array}{l}\text { Brown, light brown, } \\
\text { grayish brown, pale } \\
\text { yellow }\end{array}$ & $\begin{array}{l}\text { Mud, ash, vitric mud, } \\
\text { calcareous and siliceous } \\
\text { mud }\end{array}$ \\
\hline IIIb & $\begin{array}{l}\text { Late } \\
\text { Miocene }\end{array}$ & $444 A-5-1$ to $444 A-9-1$ & $120-159$ & 39.0 & 75.5 & $\begin{array}{l}\text { Dark brown, yel- } \\
\text { lowish brown, olive } \\
\text { brown }\end{array}$ & $\begin{array}{l}\text { Mud, siliceous mud, } \\
\text { pumice }\end{array}$ \\
\hline IVa & $\begin{array}{l}\text { Late and } \\
\text { middle } \\
\text { Miocene }\end{array}$ & $444 A-9-1$ to $444 A-12, C C$ & $159-196$ & 37.0 & & $\begin{array}{l}\text { Light olive brown, } \\
\text { pale yellowish, } \\
\text { brown }\end{array}$ & $\begin{array}{l}\text { Mud, ash, nannofossil } \\
\text { ash, siliceous mud }\end{array}$ \\
\hline $\mathrm{IVb}$ & $\begin{array}{l}\text { Middle } \\
\text { Miocene }\end{array}$ & $444 \mathrm{~A}-13-1$ to $444 \mathrm{~A}-16-3,106 \mathrm{~cm}$ & $196-228.6$ & 32.6 & 100.6 & $\begin{array}{l}\text { Dark greenish gray, } \\
\text { greenish gray, gray, } \\
\text { olive gray }\end{array}$ & $\begin{array}{l}\text { Mudstone, ash; vitric, } \\
\text { siliceous and calcareous } \\
\text { mudstone }\end{array}$ \\
\hline \multirow[t]{3}{*}{ IVc } & $\begin{array}{l}\text { Middle } \\
\text { Miocene }\end{array}$ & $444 \mathrm{~A}-16-3,107 \mathrm{~cm}$ to $444 \mathrm{~A}-19-1$ & $228.6-240.6$ & 12 & & $\begin{array}{l}\text { Dark olive gray, } \\
\text { dark greenish gray, } \\
\text { black }\end{array}$ & $\begin{array}{l}\text { Claystone, mudstone, } \\
\text { sandstone }\end{array}$ \\
\hline & & \multicolumn{6}{|c|}{ BASALT } \\
\hline & & $444 \mathrm{~A}-21$ to $444 \mathrm{~A}-22-6$ & $253-272$ & 19 & & Dark greenish gray & $\begin{array}{l}\text { Siliceous and calcareous } \\
\text { mudstone, ash }\end{array}$ \\
\hline V & $\begin{array}{l}\text { Middle } \\
\text { or early } \\
\text { Miocene }\end{array}$ & $444 A-22-7$ to $444 A-23-1$ & $272-273$ & 1 & 1 & $\begin{array}{l}\text { Reddish brown, } \\
\text { greenish gray }\end{array}$ & $\begin{array}{l}\text { Zeolitic calcareous } \\
\text { pelagic claystone, } \\
\text { nannofossil ooze }\end{array}$ \\
\hline
\end{tabular}


TABLE 3

Smear-Slide Summary, Site 444

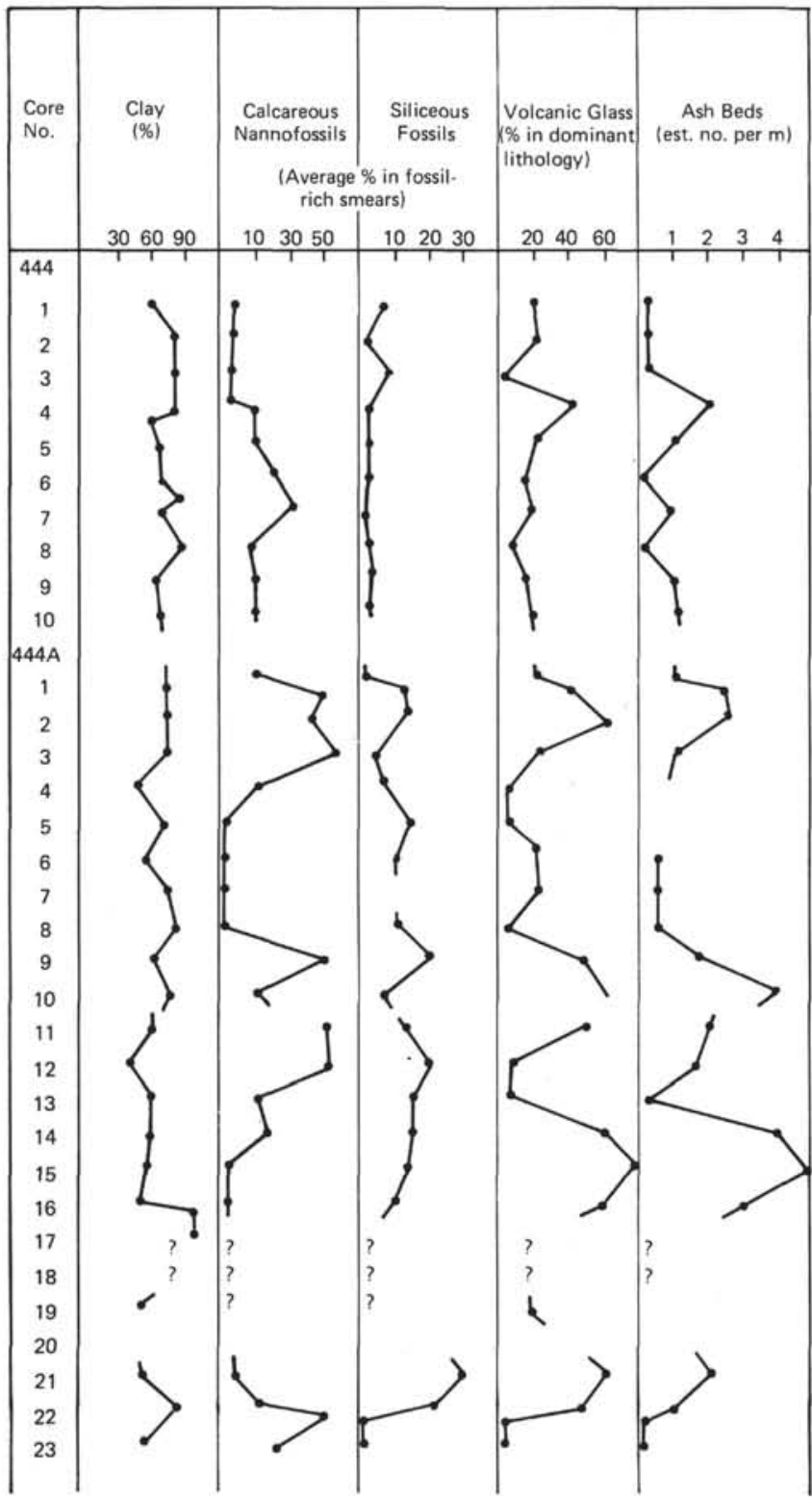

per cent. Predominant mud colors are olive-brown to olive-gray. Ash beds are very pale-brown; calcareous muds are light-gray to pale-yellow.

\section{Unit III}

Unit III is distinguished from unit II by generally brown color, a marked increase in ash beds, high glass content, abundant pumice lapillae, graded ash beds, and an increased content of microfossils. We recognized two sub-units, based on color and microfossil content.

Sub-unit IIIa consists predominantly of mud, vitric mud, ash, nannofossil mud and nannofossil ooze, and rare siliceous mud. Mud colors range from grayishbrown to olive-brown to brown. Ash beds are gray to dark-gray, so that vitric mud tends to be grayish-brown. The more-calcareous muds and nannofossil ooze are lighter in color, light-yellow-brown to pale-brown.
Ash beds are numerous; many are graded beds with sharp basal contact and sand-size glass at the base, the glass size decreasing upward. Nannofossil content (if any) increases upward. The upper contact is gradational. Some of the ash is black and semi-opaque, possibly from a basaltic source. An interesting quartz sand, about $2 \mathrm{~cm}$ thick, is present in Core 2-2,115-116 cm, at the base of a graded ash sequence. It consists of 81 per cent coarse, subangular quartz sand and 8 per cent volcanic glass.

The muds appear to be mildly bioturbated and show slight evidence of parallel bedding or lamination.

Sub-unit IIIb is distinguished from sub-unit IIIa by its higher siliceous-microfossil content, low calcareousnannofossil content, and abundance of black, semiopaque glass. The sediments of this unit consist principally of mud, vitric mud, ash, and siliceous mud. The abundance of ash may be responsible for poor core recovery of sediments in this unit. Mud colors are grayishbrown to yellowish-brown to brown. Vitric mud and ash beds tend to be very dark-grayish-brown to very darkgray, the dark color attributable to the black, semiopaque glass common in this unit. Siliceous mud, which is dark-brown to dark-grayish-brown, is common in the lower part of the unit and has a radiolarian content estimated to be as much as 30 per cent.

Ash beds have content graded bedding, fining upward, and produce lamination or parallel bedding in the muds. Basal contacts are generally sharp, upper contacts gradational. The sediments in the interval from 130 to 140 meters (mud, vitric mud, and muddy ash) are generally homogeneous and massive, but a load cast was identified at the base of an ash bed at Core $6-2,80 \mathrm{~cm}$.

\section{Univ IV}

Unit IV is distinguished from unit III by its grayish colors, increased ash, intense bioturbation, abundant calcareous nannofossils, and siliceous microfossils. We can divide the unit into three sub-units, based on differences in composition, texture, induration, and color.

Sub-unit IVa mainly includes mud, siliceous mud, mudstone, nannofossil ash, and ash. Minor radiolarian mud is present. The mud and siliceous mud colors range from yellowish-brown to light-olive-brown. Ash is lightgray to black, but an unusual reddish-black ash layer is present at the bottom of Core 10-1. Nannofossil ash and nannofossil mud are light-olive-brown to gray to grayish-brown. Ash beds are graded, fining upward, generally with sharp basal contacts and gradational upper contacts disguised by mild to intense bioturbation. Laminations or parallel bedding formed by dark components are prominent throughout. The nannofossil mudstone at $444 \mathrm{~A}-12-1,125 \mathrm{~cm}$, is a hard, well-lithified rock.

Sub-unit IVb consists of very firm to hard, dark sedimentary rocks, which thus differ from the lessindurated, lighter-colored sediments in IVa. Calcareous nannofossils are less common in IVb than in IVa. The rocks are siliceous mudstone, vitric mudstone, predominantly olive to olive-gray to dark-gray, with generally dark-olive, or dark-gray to black ash laminae or layers. 
In a few thin layers, the ash is pale-red or light-gray. Throughout the unit, ash content is high, and clay content is conspicuously lower than in sub-units IVa or IVc. The ash beds are generally graded; many show sharp bottom contacts and gradational upper contacts disturbed by moderate to intense bioturbation.

Poor recovery of Cores 17,18 , and 19 prevents a complete description of sub-unit IVc where it immediately overlies the first basalt flow. The few rock fragments recovered from Cores 17, 18, and 19 indicate that the section differs from IVb by the presence of claystones and sandstones. The rocks in the lower part of Core 16 and in Cores 21 and 22 are generally like those in IVb, but are more lithified, more massive, darker, and may contain up to 5 per cent zeolites below the first basalt.

The principal rocks are claystone, mudstone, vitric mudstone, siliceous (radiolarian) mudstone, calcareous (nannofossil) mudstone, and ash (tuff). Colors are predominantly dark, ranging from olive-gray and darkolive-gray to dark-gray, dark-greenish-gray, and black, but including light-olive-brown, greenish-gray, and gray. Ash varies from white to gray to black, or darkreddish-brown. Cores with good recovery have moderate to intense bioturbation and numerous ash beds, many of which show graded bedding, fining upward, ward, and bioturbated upper contacts.

Material recovered in Cores 17, 18, and 19-1 includes rock fragments of claystone, sandstone, and sandy mudstone. Samples of claystone from Core 17 contain an amorphous, isotropic mineraloid which resembles amorphous silica.

\section{Unit $\mathbf{V}$}

Unit $\mathrm{V}$ consists of pelagic clays, and is thus different from any other sediments recovered at Site 444 . They are mildly bioturbated, zeolitic, calcareous (nannofossil) claystone, and nannofossil ooze (chalk) which is mottled greenish-gray and dark-reddish-brown, containing as much as 60 per cent zeolites, 25 to 70 per cent nannofossils, and some micronodules. The dark-reddish-brown nannofossil chalk darkens intensely in the bottom $10 \mathrm{~cm}$ above the basalt, indicating a baked contact.

\section{ORGANIC GEOCHEMISTRY}

Organic-carbon and nitrogen contents were measured for 56 samples. Results and discussion are included elsewhere (Waples and Sloan, this volume). Several of the analyzed samples contained more than 50 per cent volcanic glass, and therefore were not classified as hemipelagic. Those samples were not included in the discussion of trends through the sedimentary sequence.

The values and trends for the hemipelagic sediments are very similar to those reported for other Leg 58 sediments. Organic-carbon and nitrogen contents are highest $(0.32$ and $0.048 \%$, respectively) near the sediment/water interface, and decrease steadily with increasing depth of busial. $\mathrm{C} / \mathrm{N}$ atomic ratios have values of about 8 in the uppermost sediments, decreasing to 3 to 5 in the deepest sediments recovered above the basalt sill.

Many samples recovered between the basalt sill and the lower basalt body showed organic-carbon values significantly higher than those of the sediments overlying the basalt (Waples, this volume). This suggests that the sill is intrusive, and that thermal effects during intrusion affected the bacterial diagenesis of organic materials. Organic geochemistry has been used to estimate the age of the intrusion as 12.2 to $13.5 \mathrm{~m}$.y. (Waples, this volume). A K-Ar age determination on this sill gives an age of $14.2 \pm 2.1 \mathrm{~m} . \mathrm{y}$. (McKee and Klock, this volume).

In contrast, the sediments immediately above the lower basalt show the carbon contents expected from the normal-diagenesis curve (Waples and Sloan, this volume), indicating that this lower basalt is not intrusive.

\section{INORGANIC GEOCHEMISTRY}

Two interstitial-water samples were taken from the sedimentary section of Hole 444, and seven from Hole 444A (Tables 4, 5). The data are also presented in Figure 4.

The average values for the geochemical parameters are as follows:

\begin{tabular}{lcll} 
& Average & & Relative to standards \\
\cline { 2 - 3 } & 7.64 & & lower \\
Alkalinity & 3.12 & & higher \\
Salinity & 35.9 & & higher \\
Chlorinity & 19.2 & & $\begin{array}{l}\text { lower (IAPSO); } \\
\text { higher (SSW) }\end{array}$ \\
$\mathrm{Ca}^{++}$ & 11.73 & higher \\
$\mathrm{Mg}^{++}$ & 50.3 & lower
\end{tabular}

All parameters are relatively constant to 162.5 meters (Core 444A-9). The $p \mathrm{H}$, alkalinity, and $\mathrm{Ca}^{++}$tend to show slight decreases with increasing depth, whereas salinity, chlorinity, and $\mathrm{Mg}^{++}$increase. $\mathrm{Mg}^{++}$is the most variable parameter to 162.5 meters.

Relative to values above 162.5 meters, all parameters show greater variability between 209.4 and 272.68 meters, spanning Cores 444A-14 through 444A-23.

The $p \mathrm{H}$ increases from 7.60 in Core $444 \mathrm{~A}-14$ to 8.16 in Core 444A-21, decreasing to 7.26 in Core 444A-23. Salinity, chlorinity, and $\mathrm{Mg}^{+}+$show similar trends, but decrease to Core 444A-21, then increase again in Core 444A-23. Alkalinity and $\mathrm{Ca}^{++}$tend to decrease with increasing depth, with minimum variability over this depth range.

The variability in these geochemical parameters for the interval 209.4 to 272.68 meters may reflect the proximity of these sediments to basalt. Basalt was first cored in Core 19, then, following the recovery of a sediment interbed, again in Core 23.

\section{BIOSTRATIGRAPHY}

A sequence of sediments from Quaternary through early middle Miocene was cored in Holes 444 and 444A, 
TABLE 4

Summary of Shipboard Geochemical Data for Hole 444

\begin{tabular}{ccccccccc}
\hline $\begin{array}{c}\text { Sample } \\
\text { (interval in cm) }\end{array}$ & $\begin{array}{c}\text { Sample } \\
\text { Number }\end{array}$ & $\begin{array}{c}\text { Sub-bottom } \\
\text { Depth }(\mathrm{m})\end{array}$ & $p \mathrm{H}$ & $\begin{array}{c}\text { Alkalinity } \\
(\mathrm{meq} / \mathrm{kg})\end{array}$ & $\begin{array}{c}\text { Salinity } \\
(\%)\end{array}$ & $\begin{array}{c}\mathrm{Ca}^{++} \\
(\mathrm{mmol} / \mathrm{l})\end{array}$ & $\begin{array}{c}\mathrm{Mg}^{++} \\
(\mathrm{mmol} / \mathrm{l})\end{array}$ & $\begin{array}{c}\mathrm{Cl}^{-} \\
(\%)\end{array}$ \\
\hline- & IAPSO & - & 8.03 & 2.50 & 35.2 & 10.55 & 53.99 & 19.375 \\
- & SSW & - & 8.33 & 2.41 & 35.5 & 10.25 & 54.05 & 18.709 \\
$444-2-4,144-150$ & 19 & $11.94-12.00$ & 7.75 & 4.24 & 35.8 & 13.07 & 48.40 & 19.242 \\
$444-7-5,144-150$ & 20 & $60.94-61.00$ & 7.52 & 3.46 & 36.0 & 12.42 & 50.88 & 19.108 \\
\hline
\end{tabular}

TABLE 5

Summary of Shipboard Geochemical Data for Hole 444A

\begin{tabular}{ccccccccc}
\hline $\begin{array}{c}\text { Sample } \\
\text { (interval in cm) }\end{array}$ & $\begin{array}{c}\text { Sample } \\
\text { Number }\end{array}$ & $\begin{array}{c}\text { Sub-bottom } \\
\text { Depth }(\mathrm{m})\end{array}$ & $p \mathrm{H}$ & $\begin{array}{c}\text { Alkalinity } \\
(\mathrm{meq} / \mathrm{kg})\end{array}$ & $\begin{array}{c}\text { Salinity } \\
(\%)\end{array}$ & $\begin{array}{c}\mathrm{Ca}^{++} \\
(\mathrm{mmol} / \mathrm{l})\end{array}$ & $\begin{array}{c}\mathrm{Mg}^{++} \\
(\mathrm{mmol} / \mathrm{l})\end{array}$ & $\begin{array}{c}\mathrm{Cl}^{-} \\
(\%)\end{array}$ \\
\hline 444A-1-5, 144-150 & 21 & $89.44-89.50$ & 7.61 & 3.40 & 35.8 & 12.11 & 51.13 & 19.042 \\
6-4, 140-150 & 22 & $135.40-135.50$ & 7.54 & 3.20 & 36.0 & 11.77 & 50.76 & 19.075 \\
$9-3,140-150$ & 23 & $162.40-162.50$ & 7.27 & 3.08 & 35.8 & 11.64 & 52.01 & 19.308 \\
$14-3,90-100$ & 24 & $209.40-209.50$ & 7.60 & 3.29 & 35.8 & 11.77 & 51.71 & 19.342 \\
$16-2,140-150$ & 25 & $227.40-227.50$ & 8.10 & 3.11 & 35.5 & 11.33 & 50.38 & 19.042 \\
$21-1,135-150$ & 26 & $254.35-254.50$ & 8.16 & 2.89 & 35.5 & 11.29 & 48.53 & 18.975 \\
$23-1,61-68$ & 27 & $272.61-272.68$ & 7.26 & 1.39 & 36.6 & 10.20 & 49.14 & 19.541
\end{tabular}

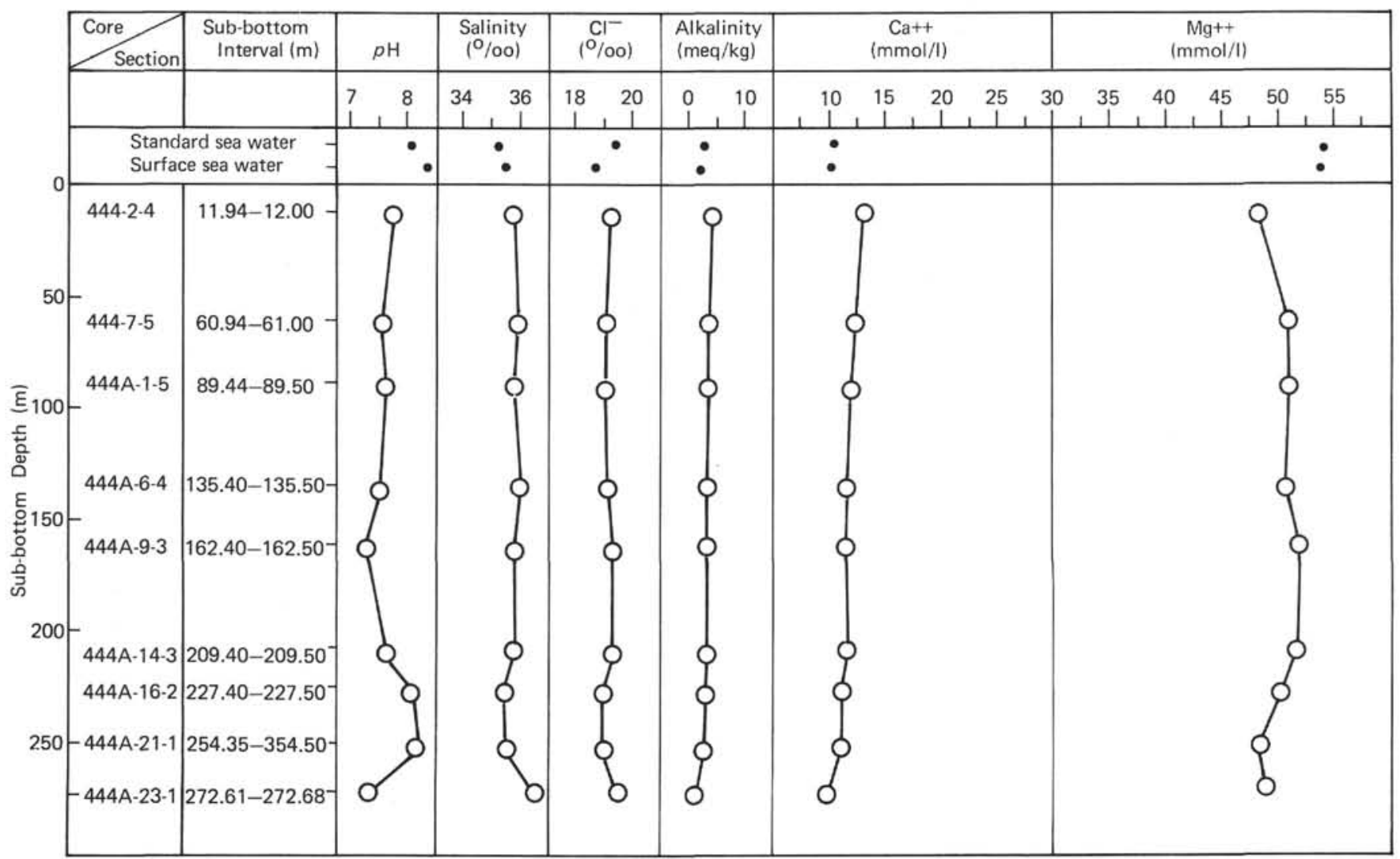

Figure 4. Interstitial-water geochemistry, Holes 444 and $444 \mathrm{~A}$.

in 4843 meters of water. Nannofossils, radiolarians, and foraminifers were studied for biostratigraphic control (Table 6).

In Hole 444, the base of the Pleistocene is placed at the base of Core 6, based on foraminifers and nannofossils. Cores 7, 8, 9, and 10 are essentially barren of planktonic foraminifers and barren of radiolarians; therefore the Pliocene age (Cores 7 and 10) is based solely on the nannofossils.

In Hole 444A, the section is essentially barren of planktonic foraminifers from the base of the Pliocene to the middle Miocene; therefore the nannofossils and radiolarians are relied upon for the chronology. Cores 1 through 4 are late late Miocene; 5 through 8 late Mio- 
TABLE 6

Biostratigraphic Zones, Site 444 (Holes 444 and 444A)

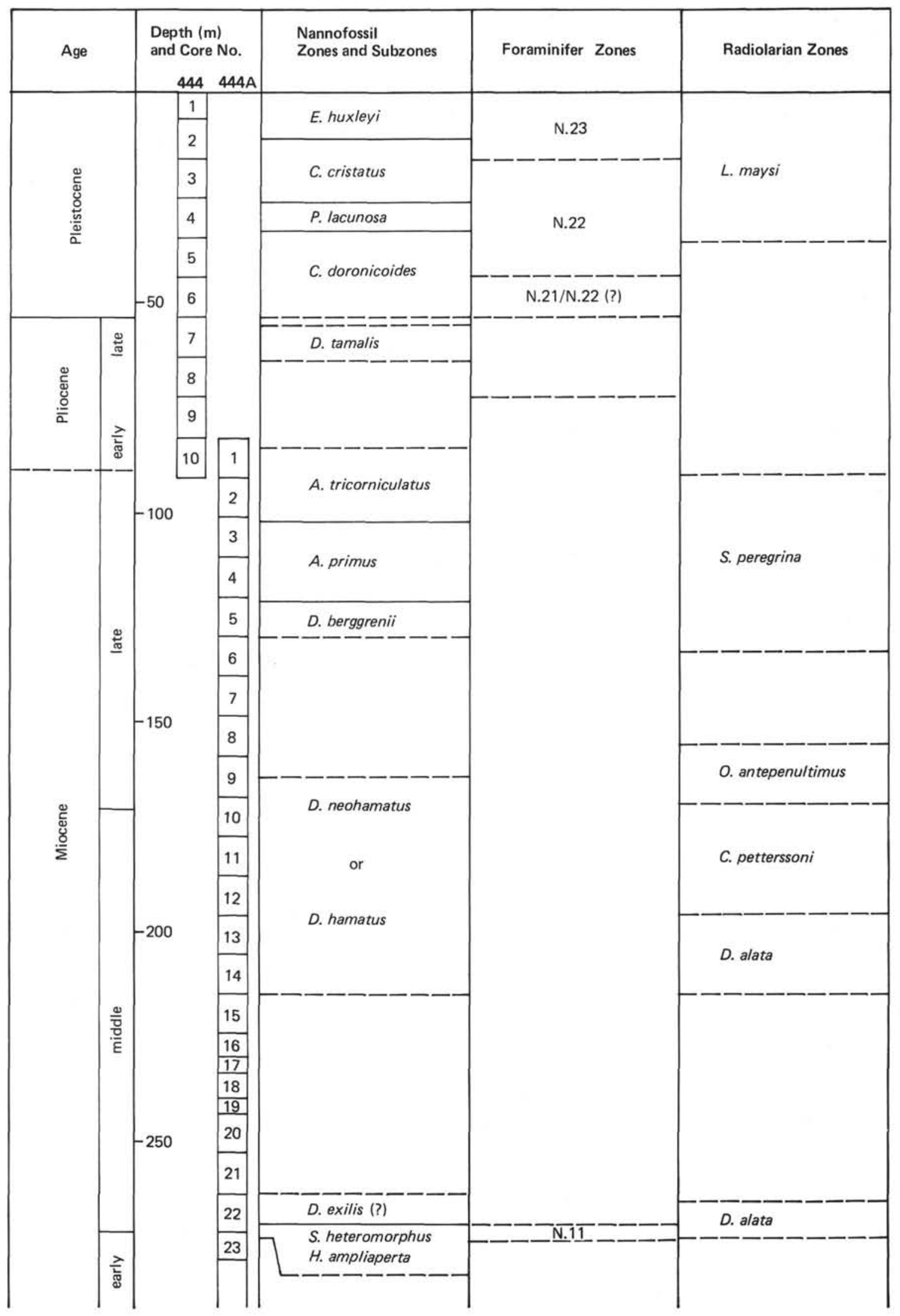


cene; 9 and 10 early late Miocene; $10, C C$ through $14, C C$ middle Miocene; and 22 and 23 late early to early middle Miocene.

The rarity or absence of planktonic foraminifers and the poor preservation and barren sequences encountered in the calcareous nannofossil distribution suggest a fluctuating lysocline and deposition close to, and in some instances below, the CCD.

Based on preservation of the nannofossils, it is estimated that deposition took place (1) at about the level of the CCD during the Quaternary; (2) slightly above the CCD during the Pliocene and late Miocene; (3) at the CCD during the late middle Miocene; and (4) possibly slightly below the CCD during the early middle Miocene.

\section{Foraminifers}

Foraminifers in Holocene through middle-Miocene sediments from Holes 444 and $444 \mathrm{~A}$ were sporadic and rare and in general poorly preserved. For this reason all the samples allotted from both holes were washed and examined for microfauna.

As in Holes 442 and 443 , the Pleistocene is represented by a fair number of identifiable planktonic foraminifers, but even there they are sporadic and not sufficiently abundant to detect short-term climatic events. In general, the rarity, low diversity, poor state of preservation, and long barren sections negate the usefulness of planktonic foraminifers for good biostratigraphic control (Table 6).

A fair number of in situ arenaceous benthic forms, not found in Holes 442 or 443 , may have some environmental significance.

In general, the sparseness of the foraminifers may be associated with climatic fluctuations and with the level of the CCD.

\section{Hole 444}

This hole was drilled to a depth of 91.5 meters, and 10 cores were recovered. The planktonic-foraminifer assemblage, although impoverished, can be recognized as Pleistocene. The fauna is dominated by the fairly large, robust species Globorotalia inflata, and specimens show various stages of dissolution. In Core 6 (53.5 meters), the presence of $G$. tosaensis and Sphaeroidinella dehiscens indicates an age of early early Pleistocene (nearly late Pliocene) (N.22/N.21 Zone; 1.6 m.y.).

The calcareous benthic forms in Cores 1 through 6 are those normally found in deep-water deposits of this age. They also show evidence of dissolution.

In Core 9, there is an arenaceous benthic assemblage consisting of fragile specimens of Reophax, Hyperammina, thin Bathysiphon, Cribrostomoides, and Cyclammina. These forms lack age significance. They do indicate, however, deposition in lower bathyal environments $(2000+$ meters $)$, and the complete absence of calcareous benthic forms or even fragmented planktonic forms signifies deposition at or below the CCD.

It was hypothesized from Pleistocene sediments at Sites 442 and 443 that deposition there also took place between the lysocline and $C C D$, at the level of the $C C D$, and in some cases below the CCD.

\section{Hole 444A}

Recovery of planktonic foraminifers was disappointing. Core 1 contains a few tiny Globigerinas, Globigerinitas, and fragmented contaminants from uphole. Cores 2 through 22 are barren of planktonic foraminifers and shows a meager and spotty distribution of benthic forms.

In smear slides and in the fraction which passed through the $63 \mu$ screen, many juveniles and "microforaminifers" were observed in scattered samples. Forms classified as juveniles are those tiny benthic or planktonic forms that have no more than a proloculus and a few chambers, whereas the "microforaminifers," although minute, are sufficiently well developed to bear adult characteristics and may be identified to genus. It has been suggested that the latter forms may represent one of the successive megalospheric generations during reproduction (Echols and Schaeffer, 1960). Not enough work has been done on these forms to evaluate their significance in interpreting past environments.

In Core 23, a meager planktonic and deep-water benthic fauna occurs in a dark-reddish pelagic clay. The fauna is silicified, but the planktonic forms are so fragile and crushed that very few whole specimens were recovered.

The sample is noteworthy, however, not only because it represents the first occurrence of anything that resembles a planktonic fauna, but also because the speculative age for the sample (late early to early middle Miocene) is equivalent to that for the core-catcher sample in Core 48, Hole 443, and close to that for Hole 442B, Core 2, Section 1.

\section{Nannofossils}

Although sporadic, nannofossils of the Pleistocene to early Miocene occur in many cores recovered at this site. Their preservation is moderately good to poor in most cores, except in the early-Pliocene to latest-Miocene sediments, where nannofossils are well preserved. Dissolution prevails through the sequences, and overgrowth is found only in the oldest sediment, immediately above basalt. Reworking is minimal in the upper cores, but becomes substantial in the lower sequences. Age identifications are summarized in Table 6.

\section{Pleistocene}

The Emiliania huxleyi Zone occurs in Samples 1,CC and 2-1, $98 \mathrm{~cm}$, whereas Samples 2,CC and 3,CC belong to the Ceratolithus cristatus Subzone. As was observed at Site 443 , the influence of the Kuroshio Current during the late Pleistocene is indicated by frequent occurrences of ceratoliths and Umbilicosphaera sibogae. These samples also contain reworked Pliocene and early-Pleistocene forms. Core 4 yields an assemblage of the middle Pleistocene (Pseudoemiliania lacunosa Subzone) and Cores 5 and 6 contain an early-Pleistocene assemblage of the Crenalithus doronicoides Zone. The 
preservation of nannofossils is moderately good to poor.

\section{Pliocene}

All core-catcher samples of Cores 7 to 10 are contaminated by Pleistocene fossils and were not considered for age identification. Samples $7-2,37 \mathrm{~cm}$ and $8-1,53 \mathrm{~cm}$ contain abundant nannofossils of the early late Pliocene (Discoaster tamalis Subzone). Since three subzones of the late Pliocene are missing between Cores $6, \mathrm{CC}$ and $7-2$, a short hiatus is suspected within this interval. An assemblage of the latest Miocene or earliest Pliocene (Amaurolithus tricorniculatus Zone) occurs in Sample 10-2, $115 \mathrm{~cm}$.

\section{Miocene}

Cores 1-1 to 2-3 contain an abundant and wellpreserved flora of the A. tricorniculatus Zone. The Miocene/Pliocene boundary probably lies between Cores 444-10 and 444A-2. Cores 3-5 to $4, \mathrm{CC}$ belong to the Amaurolithus primus Subzone. Sample 444A-5,CC contained a few poorly preserved nannofossils of the Discoaster berggrennii Subzone. Cores 6-1 to 9-3 are barren of nannofossils, except in Core 7,CC, which contains rare contaminants of Pliocene and Pleistocene age. Samples $9-4,72 \mathrm{~cm}$ to $14, \mathrm{CC}$ contain an assemblage of the late middle to early late Miocene ( $D$. hamatus or $D$. neohamatus Zone.) Nannofossils are abundant and moderately well to well preserved in the upper samples, whereas they are scarce and poorly preserved in the lower part of this sequence. Cores 15 through 20-1, where the first basalt was encountered, are essentially barren of nannofossils.

Core 21, recovered below the first layer of basalt, is barren. However, many intervals in Cores 22-1 to 23-1 contain abundant nannofossils of the early to middle Miocene. Intense dissolution is evident in the upper part of this sequence, but the nannofossils are relatively well preserved in the lower portion. In Samples 22-1, $16 \mathrm{~cm}$ and $2-4,70 \mathrm{~cm}$, Coccolithus miopelagicus, Cyclicargolithus floridanus, and five discoaster species constitute the entire assemblage. The occurrence of Discoaster exilis together with $D$. bollii suggests the Discoaster exilis Zone. Samples 22,CC and 23-1, $60 \mathrm{~cm}$ belong either to the Helicosphaera ampliaperta Zone or to the Sphenolithus heteromorphus Zone of the late early to early middle Miocene.

\section{Radiolarians}

Radiolarian preservation, ecology, and general biostratigraphic precision at Site 444 are similar to that seen elsewhere in the Shikoku Basin. Holocene and upperPleistocene material is well preserved, Pliocene sediments contain no radiolarians, and the Miocene is well represented, but biostratigraphic zones cannot be assigned with confidence (Table 6).

\section{Preservation}

The three preservational zones recognized at Site 443 are seen again at Site 444 . Core 1 to Core 4-3 of Hole 444 contain abundant, well- to moderately well-preserved served radiolarians. Cores 4 through 10 (the remainder of Hole 444) are essentially barren of radiolarians. Hole $444 \mathrm{~A}$, Core 1 ( = Core 10 of Hole 444) contains rare radiolarians. From Core 2 of Hole 444A to the first basaltic unit, radiolarians occur in all cores. Their preservation ranges from poor to good and they are rare to abundant. This sporadic preservation is believed to be due to a fluctuating amount of volcanic glass in the sediment, which both masks the abundance of siliceous microfossils and acts as an agent in their fragmentation. Below the first basaltic layer, fossiliferous sediments were again encountered and radiolarians in a similar preservation state and of similar abundance are found.

\section{Biostratigraphy}

Excluding the early Quaternary and Pliocene, radiolarians are useful in dating the sediments of Site 444 . The radiolarian stratigraphic zonation of Riedel and Sanfilippo (1978) is used; the moderately good to good radiolarian preservation in the Miocene presented an opportunity to test their tropical-radiolarian Miocene biostratigraphy in mid-latitude sediments. A mid- to high-latitude biostratigraphy for the Pliocene and Pleistocene has been formulated (Foreman, 1975; Kling, 1973), but there is no satisfactory Miocene radiolarian biostratigraphy for these latitudes. Ling (1975) noted that some Miocene species used by Riedel and Sanfilippo appear to have different ranges in the Philippine Sea than in the tropics. For these reasons, it is possible to assign radiolarian zone names to most of the Miocene material from Hole 444A, but the exact zone boundaries are indistinct.

Hole 444, Core 1 to Core 5-3 contains typical Holocene and Pleistocene radiolarian species (Theocorythium trachelium, Spongaster tetras, Ommatartus tetrathalamus, and Lamprocyrtis haysi) and is in the Lamprocyrtis haysi Zone. The remainder of Hole 444 is barren of radiolarians, and the Pliocene is not recognized.

Following this barren zone, the first core with sufficient radiolarians for an age determination is Core 2 of Hole 444A. This core contains the lower-zone-boundary species Stichocorys peregrina and is placed in that zone. The top of the $S$. peregrina Zone is marked by the first occurrence of Spongaster tetras and the loss of its immediate ancestor, $S$. berminghami. S. berminghami was not found, but the loss of the abundant mid-latitude species $S$. tetras is considered sufficient evidence to place this core in the Stichocorys peregrina Zone. Although preservation is poor to moderately good, Cores 3,4 , and 5 (Hole 444A) also are placed in the $S$. peregrina Zone (latest Miocene). Cores 8 and 9 are assigned to the early Late Miocene (Ommatartus antepenultimus Zone) and Cores 10 and 11 to the late middle Miocene (Cannartus petterssoni Zone). Cores 11 and 12 contain Cannartus laticonus, Ommartartus antepenultimus, Stichocyrs wolffii, and Crytacapsella tetrapera, but without boundary species of the genus Dorcadospyris an age of middle Miocene must be given. The remainder of the cores and of Hole 444A belong to the early middle Miocene (Dorcadospyris alata Zone). Rare Eucyrtidium diaphanes indicate that the bottom of the 
hole (Cores 21-23) is in the lower portion of the Dorcadospyris alata Zone (13.5-15 m.y.), but an age of early Miocene to latest Oligocene cannot be excluded.

\section{SEDIMENTATION RATE}

An age-depth plot is shown in Figure 5. Sediment ages were obtained using the time scales of Berggren (1972), Berggren and Van Couvering (1974), and Bukry (1975), and the modified Miocene scale of Saito (1977). Table 7 shows sediment accumulation rates calculated for each stratigraphic unit.

The sediment accumulation curve shows a low to moderate rate for almost the entire stratigraphic sequence recovered at Site 444. The highest rates occur in the Pleistocene. Pliocene rates are low. During Miocene time, rates were moderate, but less than those of Pleistocene time, except for the middle part of the middle Miocene. Sediments recovered from that interval show a very high volcanic-ash content, a finding consistent with the widespread Miocene period of explosive volcanism

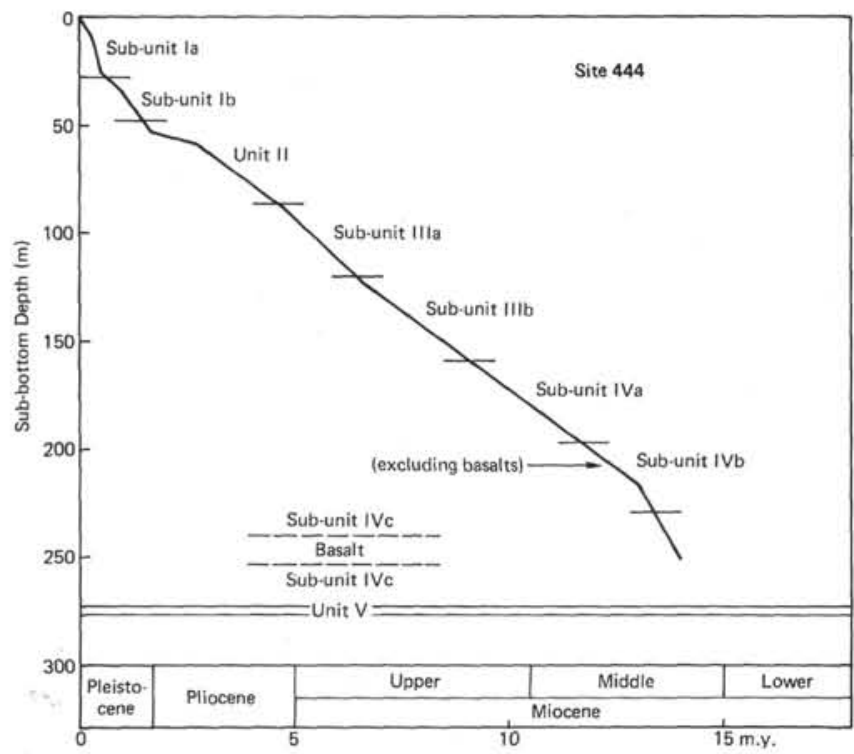

Figure 5. Sedimentation-rate curve for Site 444, based on biostratigraphy.

TABLE 7

Sedimentation Rates, Site 444

\begin{tabular}{lccc}
\hline Unit & $\begin{array}{c}\text { Depth } \\
(\mathrm{m})\end{array}$ & $\begin{array}{c}\text { Interval } \\
\text { Thickness } \\
(\mathrm{m})\end{array}$ & $\begin{array}{c}\text { Sedimentation } \\
\text { Rate }(\mathrm{m} / \mathrm{m} . \mathrm{y} .)\end{array}$ \\
\hline Ia & $0.0-28.6$ & 28.6 & 47.7 \\
Ib & $28.6-48.0$ & 19.4 & 24.3 \\
II & $48.0-83.5$ & 35.5 & 11.1 \\
IIIa & $83.5-120.0$ & 36.5 & 20.3 \\
IIIb & $120.0-159.0$ & 39.0 & 15.0 \\
IVa & $159.0-196.0$ & 37.0 & 14.8 \\
IVb & $196.0-228.6$ & 32.6 & 18.3 \\
IVc & $228.6-240.6$ & 31.1 & 51.8 \\
& Basalt & & \\
& $253.0-272.2$ & & $<1$ \\
V & $272.2-272.5$ & 0.5 & \\
\hline
\end{tabular}

known from the Pacific (Donnelly, 1975; Kennett, et al., 1977). Low rates of sediment accumulation characterize deposition of the oldest sediment, unit $\mathrm{V}$, which is a zeolitic pelagic clay.

The sediment accumulation rates for the Pleistocene at Site 444 are considerably less than those for Sites 442 and 443; we attribute this to the distal location of Site 444 with respect to sediment sources which would be exposed during sea-level fluctuations during the Pleistocene. During lower stands of sea level, both stream gradients on land and sediment yield to the basin would increase. The net volumetric increase of volcanic ash in the Pleistocene of Site 444 confirms that the volume of hemipelagic clay is less at this location, a finding consistent with the foregoing interpretation. The relatively higher sedimentation rate of the Pleistocene, with respect to the older units at Site 444 , indicates that explosive volcanism in the northwest Pacific provided a large volume of sediment to this distal site. That increased volcanism is consistent with the known increase of volcanism during the Pleistocene in the circumPacific area (Donnelly, 1975; Kennett et al., 1977).

\section{IGNEOUS PETROLOGY}

The basalts recovered from Hole $444 \mathrm{~A}$ may be divided into two units, separated by 19 meters of sediment (Figure 6).

\section{Unit 1}

Basalt was first encountered at 240.6 meters and continued to 253.0 meters; 5.46 meters were recovered before re-entering sediments. The uppermost recovered material (Core 19, Section 1, 60-63 cm, and core catcher) is drilling breccia consisting of altered and fresh basalt fragments and basaltic sand. No evidence of a chill zone or contact with either the overlying or underlying sediments was recovered.

In hand specimen, the basalt is aphyric and medium grained (diabasic), with grain sizes of 0.5 to $1.0 \mathrm{~mm}$. Pyroxene, plagioclase, and chlorite are the principal constituents. For the first $81 \mathrm{~cm}$ of the unit proper, (Core 20, Section 1, 0-81 cm), plates of chlorite up to 1 $\mathrm{cm}$ long were observed. The rest of the unit (Core 20, Section $1,81 \mathrm{~cm}$ through Section 4, $116 \mathrm{~cm}$ ) appears fresh. Occasional cross-cutting veins and fractures are lined by whitish-green clay material (smectite?).

In thin section, the basalts show a medium-grained intersertal to intergranular texture, grading to diabasic in the center of the unit.

Plagioclase contents range from 30 to 40 per cent, with laths from 0.02 to $1.5 \mathrm{~mm}$ long and 0.02 to $0.3 \mathrm{~mm}$ wide. The larger laths commonly show rim or sector zoning and fracturing. Plagioclase compositions vary, the larger laths being approximately $\mathrm{An}_{82}$ (Carlsbad-albite twin method), or at least $\mathrm{An}_{68}$ (Michel-Levy method), and small laths giving values of at least $\mathrm{An}_{60}$ (Michel-Levy method).

Pyroxene (augite; $2 \mathrm{~V}^{+}$around $45^{\circ}$ ) contents vary from 20 to 25 per cent, and grain sizes range between 0.05 and $1.5 \mathrm{~mm}$. The pyroxene grains are usually an- 


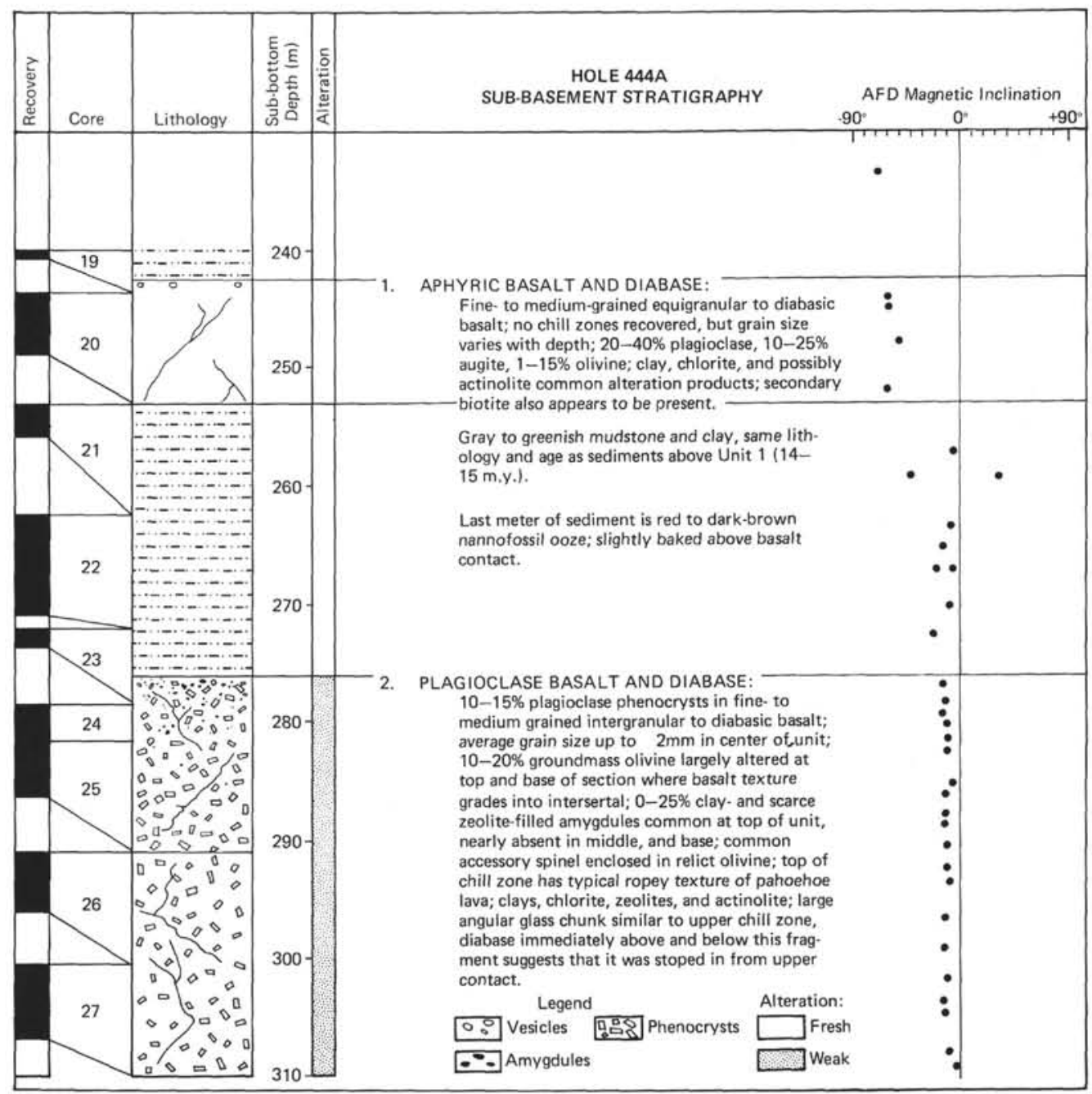

Figure 6. Sub-basement stratigraphy, Hole 444A.

hedral to subhedral, larger grains being subophitic to ophitic and occasionally show zoning.

Olivine increases from around 1 per cent or less in the upper part of the unit (444A-20-1, 27-29 cm) to 15 per cent in the lower part of the unit (444A-20-4, 46-48 cm). Olivine consists of relict grains $(0.05-0.3 \mathrm{~mm}$ across $)$ situated in pseudomorphs of chloritic material or a groundmass of fine-grained chloritic material. Occasionally, complete replacement may have occurred.

Magnetite constitutes between 2 and 3 per cent, usually as grains 0.02 to $0.3 \mathrm{~mm}$ across; elongate aggregates of several grains also occur, either acicular or sawtoothed, up to $0.5 \mathrm{~mm}$ long and $0.02 \mathrm{~mm}$ wide. Intergrown plagioclase, magnetite, and pyroxene are common.

The thin sections also show between 30 and 45 per cent fine-grained to cryptocrystalline groundmass material containing chlorite, clays, and possibly secondary biotite and actinolite. Apatite and a zeolite (chabazite?) occur as inclusions in plagioclase, and chrome spinel occurs in olivine. In 444A-20-3, 30-32 cm, chrome spinel was observed in an olivine grain which was enclosed by pyroxene.
Vesicles constitute up to 5 per cent of some pieces found in Core 19 core catcher, but were rare in the rest of the unit. The vesicles varied between 0.2 and $0.8 \mathrm{~mm}$ across.

The basalt in Core 20, Section 1,53-81 cm appears to be slightly different from the rest of the unit, in that it contains less pyroxene $(\sim 10 \%$, with a strong pinkishbrown coloration), more magnetite $(\sim 10 \%)$, and large aggregates of chlorite, up to $1 \mathrm{~cm}$ long, which are frequently cut by acicular magnetite. The acicular magnetite (0.5-2.0 mm long, 0.01-0.03 mm wide) appears to be aligned. Accessory dark-red-brown grains, possibly iddingsite, are present in a heavily altered groundmass. This area probably reflects some hydrothermal activity.

A K-Ar age determination on this sill yields an age of $14.2 \pm 2.1 \mathrm{~m} . \mathrm{y}$. (McKee and Klock, this volume).

\section{Unit 2}

Unit 2 consists of a plagioclase phyric basalt, cored from 272.7 to 310.0 meters; 21 meters were recovered. Initially, the unit consists of an amygdaloidal, aphanitic to fine-grained plagioclase phyric flow, with a chill zone 
at the top showing ropey pahoehoe texture; it contains 5 to 25 per cent amygdules and 5 to 20 per cent plagioclase phenocrysts in the chill margin. The amygdules, which are filled by a whitish-green clay (smectite?) and occasional zeolites, gradually disappear in the first 2 meters. The unit grades into a light-gray, medium-grained $(0.5-1.0 \mathrm{~mm})$ plagioclase phyric $(15-20 \%$ plagioclase phenocrysts, $1-15 \mathrm{~mm}$ across) diabase with visible medium-grained plagioclase and pyroxene. The unit is occasionally cut by carbonate- and smectite- or chlorite-lined veins and fractures. Some pyrite was observed around veins in Core 23, Section 2.

At the top of Core 26 (Section 1, 0-14 cm), a few pebbles of gray sediment similar to that found in Cores 21 and 22 occurred along with a small piece $(\sim 5 \times 4 \mathrm{~cm})$ of aphanitic plagioclase phyric (5\% plagioclase phenocrysts, $2-5 \mathrm{~mm}$ long) basalt with approximately 3 per cent vesicles $(<2 \mathrm{~mm})$. The piece has a glassy margin and resembles that found at the top of unit 2. This material occurs in the center of the unit, which is medium grained, showing no sign of chilling, and therefore considered to represent up-hole contamination.

Thin-section studies indicate that grain size in the unit increases from the top, reaching a maximum around the base of Core 26 ( $\sim 296$ meters sub-bottom), and decreasing slightly after this in Core 27. Relict olivine and magnetite generally show a similar pattern.

Plagioclase constitutes 30 to 50 per cent of the rock, 2 to 30 per cent as phenocrysts ( $10-15 \%$ average), ranging in size from $1.0 \times 0.5$ to $7.0 \times 3.0 \mathrm{~mm}$. Sizes of plagioclase microphenocryst laths vary from 0.05 to 0.6 $\mathrm{mm}$ at the top of the unit to 0.4 to $2.5 \mathrm{~mm}$ in Core 26 , decreasing to 0.05 to $1.0 \mathrm{~mm}$ in Core 27. There is a complete range of plagioclase compositions from calcic phenocrysts ( $\geq A n_{70}$, Michel-Levy method) to moresodic microphenocrysts ( $\mathrm{An}_{60}$, Michel-Levy method). Sector or rim zoning (up to six zones) is commonly observed in the large plagioclase phenocrysts, as are aligned vacuoles and inclusions of a brown, rectangular, moderately birefringent mineral (generally $0.01 \times 0.02$ $\mathrm{mm})$.

Pyroxene (augitic composition) contents vary between 25 and 30 per cent. Ranges of grain size are 0.05 to $0.5 \mathrm{~mm}$ at the top of the unit, 0.2 to $6.0 \mathrm{~mm}$ in the center of the unit (Core 26), and 0.05 to $0.6 \mathrm{~mm}$ at the base of the unit. The larger pyroxenes are subophitic or ophitic.

Relict olivine grains were observed only in the middle and lower parts of the unit. The content increases from approximately 1 per cent at the top of Core 25 to almost 10 per cent in Core 26, Section 3, 67-69 $\mathrm{cm}$, then decreases to 1 per cent in Core 27. The relict olivine grains are surrounded by chloritic alteration products, sometimes recognizable as pseudomorphs. Inclusions of dark-red-brown chrome spinel (0.01-0.02 $\mathrm{mm}$ across) occur in the relict olivine.

Magnetite contents vary between 1 and 5 per cent and are generally higher in the middle of the unit than at the top or in the lower part. Grain sizes of magnetite vary from 0.02 to $1.0 \mathrm{~mm}$, usually being coarser in the center of the unit.
The groundmass consists of fine-grained to cryptocrystalline chlorite, clays, and possibly fibrous actinolite. This material constitutes 10 to 30 per cent of the basalt. Odd grains of calcite also occur in Section 444A-24-3, 21-23 cm.

\section{Geochemistry}

The geochemistry of these basalts is discussed in detail elsewhere in this volume. Unit 1, the upper sill, shows higher concentrations of some incompatible trace elements (e.g., $\mathrm{Zr}$ and light REE). However, other incompatible trace elements and minor elements (e.g., $\mathrm{Ti}$ and $\mathrm{Y}$ ) have values similar to other basalts from the Shikoku Basin.

The lower sill, unit 2, appears to be similar to other Shikoku Basin material, although slightly more fractionated.

\section{Age and Emplacement}

The two basalt units drilled at Site 444 show different palaeomagnetic inclinations (unit 1: average reversed inclination of $58.7^{\circ}$; unit 2 : average reversed inclination of $12.3^{\circ}$ ). This evidence suggests that they are not of comparable age.

Thermal effects suggest that they were intruded into the adjacent sediments. These effects include (1) a thin layer of baked (?) sediment overlying unit 2; (2) the production of anomalies in the organic-carbon content of the sediments; and (3) unusually consistent palaeomagnetic inclinations in the overlying sediments, particularly for unit 2.

Supporting petrological evidence for the designation of these units as sills includes (1) lack of pillows or thick, glassy margins, both of which would be expected in sub-aqueous flows; (2) a general coarsening of grain size towards the center of each unit, indicating similar cooling above and below; (3) olivine maximum at about two thirds of the depth of the units; this feature was also observed at Site 443 and indicates that the base of Unit 2 probably was not far beyond the final depth of Hole 444A; (4) magnetite distributions which exhibit a similar, but not as marked variation.

These vertical variations of grain size, olivine and magnetite distributions suggest that the units lie parallel to the sedimentary bedding.

Organic-carbon measurements suggest that the upper sill, unit 1, may have been intruded between 12.2 and 13.5 Ma. A K-Ar age determination on the upper sill yielded an age of $14.2 \pm 2.1$ m.y. (McKee and Klock, this volume). It is only possible to assign a maximum age to the lower sill, unit 2; this is the paleontological age of $15 \mathrm{~m} . \mathrm{y}$. for the overlying sediments.

\section{PALEOMAGNETISM}

\section{Sedimentary Layers}

About 272 meters of sediments were drilled at Hole 444 and Hole 444A, from which cylindrical samples were taken from the cored sections. Measurements of NRM and AF-demagnetized NRM were carried out by 
means of a spinner magnetometer (Site 442 report). Maximum AF was 150 oe, decreasing to zero at a constant rate of 10 milligauss/cycle. All data, including sample positions, magnetization measurements, and other parameters, are listed in Table 8. Changes of NRM polarity with respect to sub-bottom depth are shown in Figure 7. Absolute values of NRM inclination are plotted in Figure 8. The sediment samples were arbitrarily divided into four 50-meter intervals of sub-bottom depth, and a statistical treatment was applied. No tendency was found in the relation of NRM inclination values to sub-bottom depth.

\section{Basalt Samples}

Two basalt sequences were penetrated at this site. A basalt of about 5.5 meters was recovered from an upper sequence, and one of about 12 meters from a lower sequence. Between the two basalts is a sediment interbed. Recovery of the sediment cores just above and below the uppermost basalt is poor, probably because of washout. Twenty-five cylindrical minicores were taken from the basalt cores for paleomagnetism study. NRM and AFdemagnetized NRM were measured in the manner described for Site 442. Results of measurements are given in Table 9. All the samples except for one are magnetically soft, showing a relatively low MDF, from 30 to 140 oe, as illustrated in Figure 9 . Nevertheless, it is likely that AF-demagnetized NRM reveals inclination of the past geomagnetic field with high fidelity. This is shown clearly in the inclination values of Figure 10. In the top layer of basalt, inclination values cluster around 60 degrees (negative), and scatter is relatively small. In the underlying layer they are clustered around 13 degrees (negative), and scatter is small, as shown in Table 10. Moreover, it is striking to observe that the AF-demagnetized NRM inclinations of sediment samples from above both the basaltic layers fall very close to NRM inclinations of the basalts.

\section{Summary for Site 444}

The results are summarized as follows:

1. Remanent magnetism of both sediment and basalt samples is sufficiently stable to provide data about paleomagnetic inclination.

2. NRM intensity of basalt at Hole 444A is lower than that of typical oceanic basalt.

3. The mean value of NRM inclination of sediments is close to 35 degrees for the top 200 meters, with very large scatter below.

4. The top layer of basalts is reversely magnetized, with high absolute inclination, in contrast to the underlying layer with low inclination values.

5. Inclinations of stable NRM of basalt and that of sediment just above the basalt are similar.

These results lead to the following conclusions:

1. Because NRM of basalts of Hole $444 \mathrm{~A}$ is weak (1-2 $\times 10^{-3}$ gauss $\left./ \mathrm{cm}^{3}\right)$ and the rocks are reversely magnetized, the penetrated basalts cannot be the source of the positive geomagnetic anomaly at this site.

2. Although NRM inclination values of the sediments are largely scattered, their mean values suggest
TABLE 8

Paleomagnetism Measurements of Sedimentary Cores from Site $444^{\mathrm{a}}$

\begin{tabular}{|c|c|c|c|c|c|c|}
\hline \multirow{2}{*}{$\begin{array}{c}\text { Sample } \\
\text { (interval in } \mathrm{cm} \text { ) }\end{array}$} & \multirow{2}{*}{$\begin{array}{l}\text { Sub-bottom } \\
\text { Depth (m) }\end{array}$} & \multirow{2}{*}{$\begin{array}{c}J_{\mathrm{NRM}} \\
\left(10^{-5} \text { gauss }\right)\end{array}$} & \multirow{2}{*}{$\begin{array}{l}\text { Susceptibility } \\
\left(10^{-5} \text { gauss/oe) }\right.\end{array}$} & \multicolumn{2}{|c|}{ Inclination } & \multirow[b]{2}{*}{ Polarity } \\
\hline & & & & NRM & AFD & \\
\hline $\begin{array}{c}444-3-1,12-14 \\
3-2,22-24 \\
4-1,116-118 \\
4-2,116-118 \\
4-3,20-22\end{array}$ & $\begin{array}{l}15.63 \\
17.23 \\
26.15 \\
27.67 \\
28.21\end{array}$ & $\begin{array}{l}1.86 \\
1.52 \\
2.20 \\
1.61 \\
4.48\end{array}$ & $\begin{array}{l}0.36 \\
0.27 \\
0.25 \\
0.37 \\
0.36\end{array}$ & $\begin{array}{r}-39.6 \\
-49.7 \\
-20.2 \\
28.5 \\
-69.8\end{array}$ & $\begin{array}{r}-30.5 \\
-43.5 \\
-25.5 \\
22.8 \\
-69.6\end{array}$ & $\begin{array}{l}- \\
+ \\
+ \\
-\end{array}$ \\
\hline $\begin{array}{l}4-3,114-116 \\
5-1,76-78 \\
5-2,92-94 \\
5-3,60-62 \\
5-4,68-70\end{array}$ & $\begin{array}{l}29.15 \\
35.25 \\
36.93 \\
38.11 \\
39.69\end{array}$ & $\begin{array}{l}0.14 \\
4.50 \\
2.24 \\
6.03 \\
3.14\end{array}$ & $\begin{array}{l}0.40 \\
0.54 \\
0.23 \\
0.47 \\
0.40\end{array}$ & $\begin{array}{r}-1.6 \\
-26.1 \\
21.0 \\
-70.4 \\
-19.8\end{array}$ & $\begin{array}{r}44.6 \\
-25.4 \\
22.1 \\
-71.4 \\
-27.9\end{array}$ & $\begin{array}{l}-1+ \\
- \\
+ \\
-\end{array}$ \\
\hline $\begin{array}{l}7-1,50-52 \\
7-2,77-79 \\
7-3,43-45 \\
7-4,12-14 \\
7-6,28-30\end{array}$ & $\begin{array}{l}54.01 \\
55.78 \\
56.92 \\
58.13 \\
61.29\end{array}$ & $\begin{array}{l}1.64 \\
1.65 \\
2.13 \\
2.20 \\
2.87\end{array}$ & $\begin{array}{l}0.52 \\
0.43 \\
0.76 \\
0.69 \\
0.59\end{array}$ & $\begin{array}{r}16.5 \\
64.2 \\
24.6 \\
1.7 \\
55.4\end{array}$ & $\begin{array}{l}17.8 \\
66.2 \\
30.8 \\
15.0 \\
55.6\end{array}$ & $\begin{array}{l}+ \\
+ \\
+ \\
+ \\
+\end{array}$ \\
\hline $\begin{array}{l}9-1,110-112 \\
10-1,52-54 \\
10-2,52-54\end{array}$ & $\begin{array}{l}73.61 \\
82.53 \\
83.93\end{array}$ & $\begin{array}{l}6.86 \\
1.59 \\
0.04^{b}\end{array}$ & $\begin{array}{l}0.68 \\
0.35 \\
0.29\end{array}$ & $\begin{array}{r}-17.2 \\
18.7 \\
1.0\end{array}$ & $\begin{array}{r}-15.0 \\
21.8 \\
45.9\end{array}$ & $\begin{array}{l}+ \\
+ \\
+\end{array}$ \\
\hline $\begin{array}{r}444 \text { A-1-1, } 64-66 \\
1-2,64-66 \\
1-3,64-66 \\
1-4,64-66 \\
1-5,64-66\end{array}$ & $\begin{array}{l}82.65 \\
84.15 \\
85.65 \\
87.15 \\
88.65\end{array}$ & $\begin{array}{l}2.35 \\
0.09 \\
1.13 \\
2.19 \\
8.35\end{array}$ & $\begin{array}{l}0.46 \\
0.33 \\
0.38 \\
0.54 \\
0.54\end{array}$ & $\begin{array}{r}61.4 \\
27.3 \\
-11.8 \\
20.0 \\
32.2\end{array}$ & $\begin{array}{r}60.8 \\
14.0 \\
-25.3 \\
23.9 \\
30.7\end{array}$ & $\begin{array}{l}+ \\
+ \\
+ \\
+\end{array}$ \\
\hline $\begin{array}{l}1-6,64-66 \\
2-2,92-94 \\
2-3,23-25 \\
2-4,23-25 \\
3-2,62-64\end{array}$ & $\begin{array}{r}90.15 \\
93.23 \\
94.74 \\
96.24 \\
103.13\end{array}$ & $\begin{array}{l}2.83 \\
0.30 \\
2.74 \\
6.52 \\
1.49\end{array}$ & $\begin{array}{l}0.47 \\
0.38 \\
0.60 \\
0.62 \\
0.55\end{array}$ & $\begin{array}{r}55.0 \\
47.6 \\
-61.6 \\
41.4 \\
4.7\end{array}$ & $\begin{array}{r}58.7 \\
4.4 \\
-61.1 \\
42.3 \\
11.8\end{array}$ & $\begin{array}{l}+ \\
+ \\
+ \\
+ \\
+\end{array}$ \\
\hline $\begin{array}{l}3-3,62-64 \\
3-4,62-64 \\
3-5,62-64 \\
6-1,38-40 \\
6-2,38-40\end{array}$ & $\begin{array}{l}104.63 \\
106.13 \\
107.63 \\
129.89 \\
131.39\end{array}$ & $\begin{array}{l}2.93 \\
2.05 \\
1.99 \\
1.24 \\
3.42\end{array}$ & $\begin{array}{l}0.76 \\
0.59 \\
0.53 \\
0.42 \\
0.50\end{array}$ & $\begin{array}{r}-63.3 \\
-47.9 \\
-45.1 \\
-29.4 \\
59.5\end{array}$ & $\begin{array}{r}-63.1 \\
-45.4 \\
-47.5 \\
-30.7 \\
58.1\end{array}$ & $\begin{array}{l}\overline{-} \\
\bar{z} \\
+\end{array}$ \\
\hline $\begin{array}{l}6-3,38-40 \\
6-4,38-40 \\
6-5,38-40 \\
7-1,56-58 \\
8-1,69-71\end{array}$ & $\begin{array}{l}132.89 \\
134.39 \\
135.89 \\
139.57 \\
149.20\end{array}$ & $\begin{array}{l}1.48 \\
5.35 \\
2.63 \\
1.70 \\
1.58\end{array}$ & $\begin{array}{l}0.32 \\
0.39 \\
0.51 \\
0.68 \\
0.45\end{array}$ & $\begin{array}{r}30.7 \\
57.7 \\
29.7 \\
40.3 \\
-26.9\end{array}$ & $\begin{array}{r}33.2 \\
39.8 \\
25.1 \\
46.3 \\
-24.3\end{array}$ & $\begin{array}{l}+ \\
+ \\
+ \\
+ \\
+\end{array}$ \\
\hline $\begin{array}{l}9-1,28-30 \\
9-2,28-30 \\
9-3,28-30 \\
9-4,28-30 \\
9-5,28-30\end{array}$ & $\begin{array}{l}158.29 \\
159.79 \\
161.29 \\
162.79 \\
164.29\end{array}$ & $\begin{array}{l}5.25 \\
3.11 \\
2.06 \\
5.59 \\
0.45\end{array}$ & $\begin{array}{l}0.70 \\
1.27 \\
0.96 \\
1.10 \\
1.13\end{array}$ & $\begin{array}{l}-24.5 \\
-26.6 \\
-15.7 \\
-22.5 \\
-53.7\end{array}$ & $\begin{array}{l}-25.1 \\
-35.0 \\
-36.2 \\
-28.3 \\
-41.2\end{array}$ & $\begin{array}{l}\bar{z} \\
\bar{z}\end{array}$ \\
\hline $\begin{array}{l}10-1,104-106 \\
10-2,104-106 \\
11-1,112-114 \\
11-2,118-120 \\
11-3,115-117\end{array}$ & $\begin{array}{l}168.55 \\
170.05 \\
178.13 \\
179.69 \\
181.16\end{array}$ & $\begin{array}{l}3.34 \\
4.15 \\
4.41 \\
3.66 \\
2.04\end{array}$ & $\begin{array}{l}1.79 \\
1.27 \\
0.53 \\
1.00 \\
0.45\end{array}$ & $\begin{array}{r}49.0 \\
1.9 \\
24.9 \\
-16.8 \\
-33.5\end{array}$ & $\begin{array}{r}50.3 \\
-11.4 \\
25.8 \\
-17.8 \\
-39.2\end{array}$ & $\begin{array}{c}+ \\
+ \\
+ \\
+ \\
-\end{array}$ \\
\hline $\begin{array}{l}11-4,60-62 \\
12-1,94-96 \\
12-2,119-121 \\
13-1,91-93 \\
13-2,68-70\end{array}$ & $\begin{array}{l}182.11 \\
187.45 \\
189.20 \\
196.90 \\
198.19\end{array}$ & $\begin{array}{l}1.90 \\
0.57 \\
7.84 \\
8.19 \\
1.50\end{array}$ & $\begin{array}{l}0.93 \\
0.69 \\
0.96 \\
1.72 \\
1.09\end{array}$ & $\begin{array}{r}-44.5 \\
15.6 \\
-59.7 \\
73.5 \\
51.5\end{array}$ & $\begin{array}{r}-48.1 \\
4.3 \\
-58.6 \\
70.4 \\
2.8\end{array}$ & $\begin{array}{l}\dot{+} \\
\dot{+} \\
+\end{array}$ \\
\hline $\begin{array}{l}13-3,30-32 \\
14-1,73-75 \\
14-2,73-75 \\
14-3,73-75 \\
15-1,44-46\end{array}$ & $\begin{array}{l}199.31 \\
206.24 \\
207.74 \\
209.24 \\
215.45\end{array}$ & $\begin{array}{l}5.24 \\
5.69 \\
7.64 \\
6.64 \\
8.14\end{array}$ & $\begin{array}{l}1.06 \\
0.96 \\
0.69 \\
0.47 \\
0.98\end{array}$ & $\begin{array}{r}-26.1 \\
54.8 \\
36.4 \\
34.0 \\
38.1\end{array}$ & $\begin{array}{r}-27.2 \\
55.4 \\
35.1 \\
37.8 \\
37.9\end{array}$ & $\begin{array}{l}+ \\
+ \\
+ \\
+ \\
+\end{array}$ \\
\hline $\begin{array}{c}444 \mathrm{~A}-15-2,44-46 \\
15-3,44-46 \\
16-1,44-46 \\
16-2,110-112 \\
16-3,130-132\end{array}$ & $\begin{array}{l}216.95 \\
218.45 \\
224.95 \\
227.09 \\
228.81\end{array}$ & $\begin{array}{l}2.30 \\
6.00 \\
8.46 \\
9.35 \\
7.85\end{array}$ & $\begin{array}{l}0.49 \\
0.77 \\
0.63 \\
0.62 \\
1.30\end{array}$ & $\begin{array}{r}31.0 \\
53.6 \\
12.4 \\
-46.3 \\
-63.0\end{array}$ & $\begin{array}{r}32.3 \\
55.6 \\
10.5 \\
-46.7 \\
-58.0\end{array}$ & $\begin{array}{l}+ \\
+ \\
+ \\
-\end{array}$ \\
\hline $\begin{array}{l}17-1,25-27 \\
21-1,122-124 \\
21-2,33-35 \\
21-2,35-37 \\
21-2,39-41\end{array}$ & $\begin{array}{l}234.26 \\
254.23 \\
254.84 \\
254.86 \\
254.90\end{array}$ & $\begin{array}{r}2.97 \\
2.36 \\
10.78 \\
12.20 \\
8.64\end{array}$ & $\begin{array}{l}0.44 \\
1.72 \\
1.03 \\
1.15 \\
1.13\end{array}$ & $\begin{array}{r}-75.7 \\
-1.8 \\
43.6 \\
29.1 \\
33.0\end{array}$ & $\begin{array}{r}-69.5 \\
-6.4 \\
41.6 \\
31.8 \\
30.4\end{array}$ & $\begin{array}{l}- \\
+ \\
+ \\
+\end{array}$ \\
\hline $\begin{array}{l}22-1,75-77 \\
22-2,75-77 \\
22-3,95-97 \\
22-3,99-101 \\
22-5,75-77\end{array}$ & $\begin{array}{l}263.26 \\
264.76 \\
266.46 \\
266.50 \\
269.26\end{array}$ & $\begin{array}{l}5.39 \\
2.37 \\
2.34 \\
5.80 \\
2.37\end{array}$ & $\begin{array}{l}0.58 \\
0.66 \\
0.51 \\
0.67 \\
0.49\end{array}$ & $\begin{array}{r}-4.5 \\
-2.6 \\
1.7 \\
-16.5 \\
-5.3\end{array}$ & $\begin{array}{r}-7.9 \\
-14.2 \\
-7.4 \\
-21.5 \\
-9.6\end{array}$ & $\bar{z}+$ \\
\hline $22-6,146-148$ & 271.47 & 6.06 & 0.24 & -23.0 & -24.1 & - \\
\hline
\end{tabular}

a AFD is obtained by peak alternating demagnetizing field of 150 oe, decreasing to zero at a constant rate of 20 milligauss/cycle; polarity shows whether the inclination of NRM is positive $(+)$ or negative $(-)$.

that the paleolatitude of this area in the middle Miocene was a little lower than the present latitude.

3. There is evidence that the sediments just above both the basaltic layers were heated to a certain temperature at which sediment was remagnetized and realigned close to NRM direction of the basalt (i.e., parallel to the 


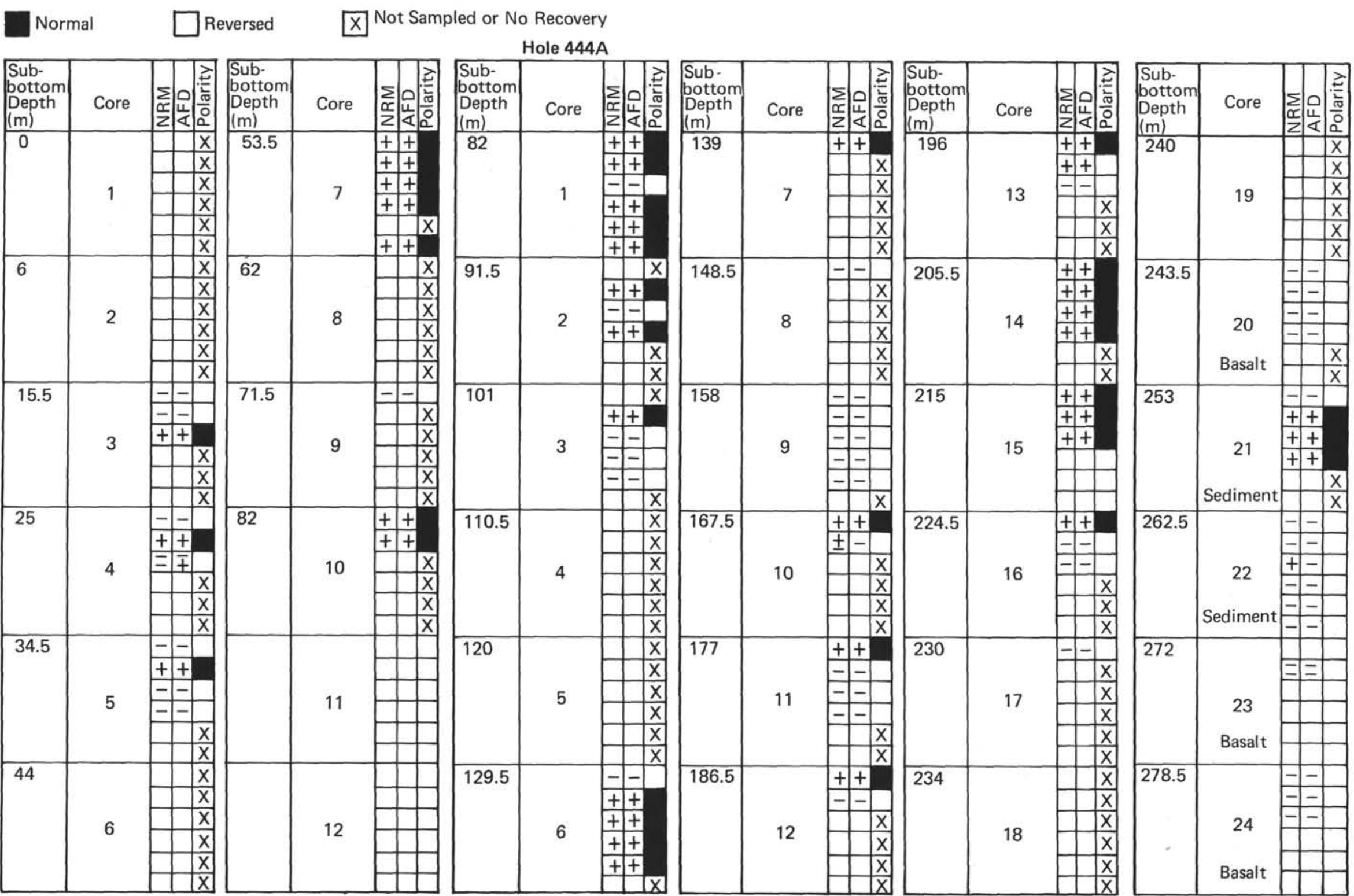

Figure 7. Results listed in Table 8, illustrated in descending order of cores and section, for Holes 444 and 444 A. Polarity diagrams of some basalt cores next to the bottom layer of the sediments are also shown. 


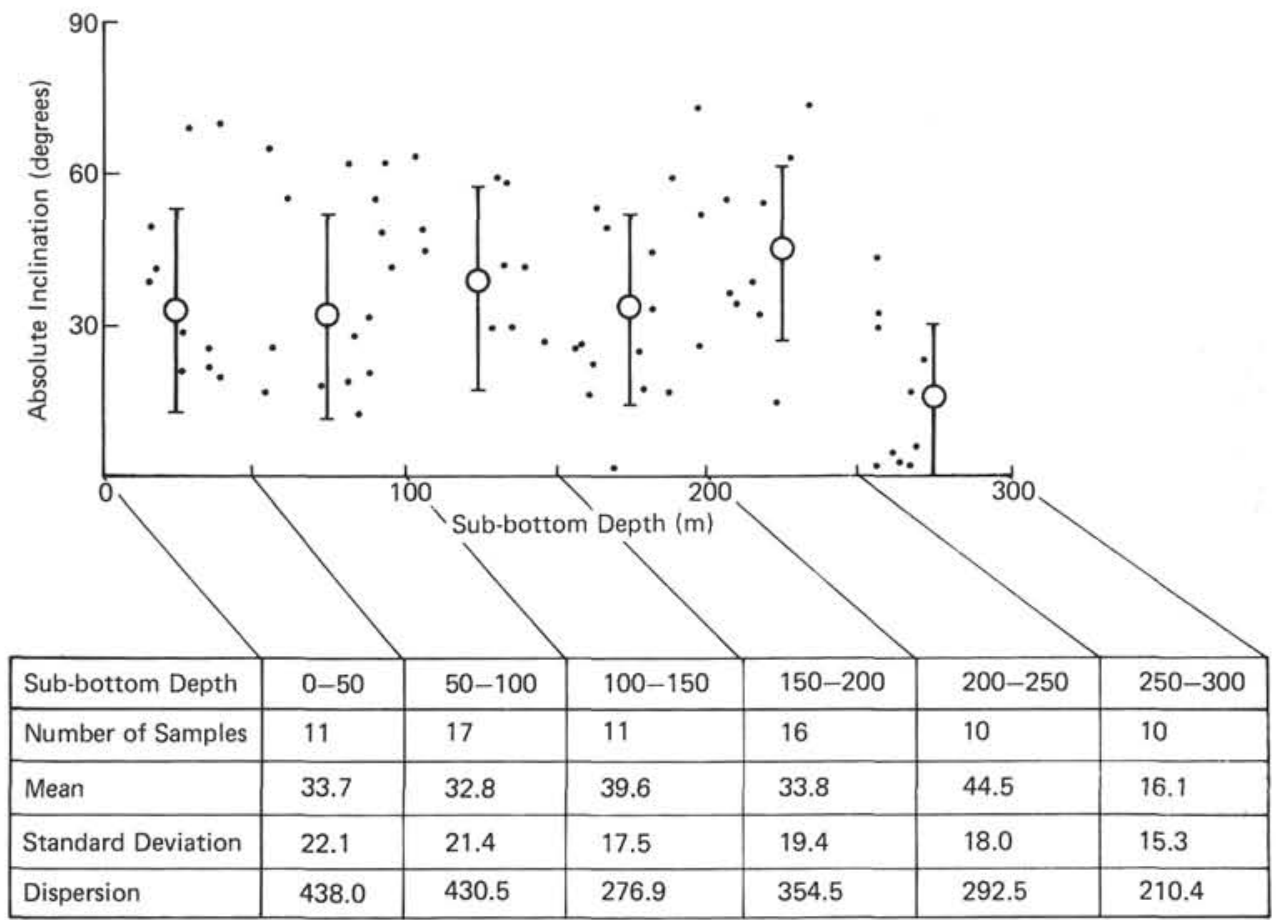

Figure 8. Absolute values of inclination of NRM versus sub-bottom depth of the sedimentary layers. Open circles are mean values of the inclination taken every 50 meters. Vertical bars represent standard deviations. Also shown are statistics of NRM inclinations of sedimentary cores, grouped every 50 meters.

TABLE 9

Paleomagnetism of Basalts, Hole $444 \mathrm{~A}^{\mathrm{a}}$

\begin{tabular}{|c|c|c|c|c|c|c|c|c|}
\hline $\begin{array}{c}\text { Sample } \\
\text { (interval in } \mathrm{cm} \text { ) }\end{array}$ & $\begin{array}{l}\text { Sub-bottom } \\
\text { Depth } \\
\text { (m) }\end{array}$ & $\begin{array}{c}J_{\mathrm{NRM}} \\
\left(10^{-5} \text { gauss }\right)\end{array}$ & $\begin{array}{l}\text { Inclination } \\
\text { NRM }\end{array}$ & $\begin{array}{l}\text { Inclination } \\
\text { AFD }\end{array}$ & $\begin{array}{l}\text { MDF } \\
\text { (oe) }\end{array}$ & $\begin{array}{c}X_{\text {in }} \\
\left(10^{-5} \text { gauss/oe }\right)\end{array}$ & $Q_{n}^{\prime}$ & Remarks \\
\hline $444 \mathrm{~A}-20-1,27-29$ & 243.78 & 58.9 & -55.3 & -60.9 & 55 & 4.28 & 31.8 & 100 oe \\
\hline $20-1,71-73$ & 244.22 & 119.8 & -54.6 & -60.2 & 45 & 8.23 & 33.6 & 50 oe \\
\hline $20-2,88-90$ & 245.89 & 27.0 & -26.2 & -51.9 & 35 & 4.23 & 14.7 & $50 \mathrm{oe}$ \\
\hline $20-4,46-48$ & 248.47 & 31.9 & -69.8 & -61.7 & 75 & 4.00 & 18.4 & 100 oe \\
\hline $23-2,87-89$ & 274.38 & 217.3 & -8.7 & -16.2 & 105 & 8.50 & 59.0 & 150 oe \\
\hline $23-2,138-140$ & 274.89 & 311.5 & -11.2 & -13.4 & 130 & 6.13 & 117.2 & 150 oe \\
\hline $24-1,73-75$ & 279.24 & 152.6 & -33.5 & -16.2 & 115 & 7.53 & 46.8 & 150 oe \\
\hline $24-2,30-32$ & 280.31 & 143.5 & -17.0 & -11.8 & 105 & 6.79 & 48.8 & 150 oe \\
\hline $24-3,21-23$ & 281.72 & 408.3 & -11.3 & - & - & 5.92 & 159.2 & - \\
\hline $25-1,49-51$ & 282.00 & 336.0 & -13.4 & -12.8 & 125 & 4.65 & 166.8 & 150 oe \\
\hline $25-2,50-52$ & 283.51 & 292.5 & -12.2 & -8.8 & 95 & 9.71 & 69.5 & 100 oe \\
\hline $25-2,109-111$ & 284.10 & 96.7 & -7.7 & -13.8 & 90 & 8.23 & 27.1 & 100 oe \\
\hline $25-3,44-46$ & 284.95 & 121.3 & -13.6 & -12.8 & 85 & 6.86 & 40.9 & 100 oe \\
\hline $25-3,92-94$ & 285.43 & 282.6 & -11.3 & -13.6 & 160 & 6.43 & 101.4 & 200 oe \\
\hline $25-4,38-40$ & 286.39 & 463.1 & -9.5 & -12.4 & 110 & 7.58 & 141.0 & 150 oe \\
\hline $26-1,75-77$ & 291.76 & 210.7 & -12.3 & -11.7 & 100 & 8.62 & $21 G .8$ & 100 oe \\
\hline $26-2,05-07$ & 292.56 & 96.8 & -0.4 & -9.3 & 45 & 11.42 & 96.8 & 50 oe \\
\hline $26-3,68-70$ & 294.69 & 64.2 & -6.6 & -13.2 & 35 & 8.35 & 64.3 & 50 oe \\
\hline $26-4,63-65$ & 296.14 & 42.0 & -38.7 & -15.0 & 145 & 7.30 & 13.3 & 150 oe \\
\hline $27-1,90-92$ & 301.41 & 46.4 & -15.1 & -10.1 & 260 & 8.62 & 12.4 & 300 oe \\
\hline $27-2,93-95$ & 303.85 & 51.9 & -25.0 & -14.1 & 70 & 8.65 & 13.8 & 100 oe \\
\hline $27-3,43-45$ & 304.85 & 33.9 & 5.5 & -13.9 & 140 & 9.02 & 8.7 & 150 oe \\
\hline $27-4,83-85$ & 306.75 & 39.4 & -13.0 & -10.3 & 65 & 9.16 & 9.9 & 100 oe \\
\hline $27-5,39-91$ & 307.81 & 38.7 & 3.5 & -4.8 & 70 & 9.73 & 9.2 & $100 \mathrm{oe}$ \\
\hline
\end{tabular}

aMDF is the median destructive field (of AF demagnetization) at which the remanent magnetism of a specimen decreases to $50 \%$ of its initial value; $X_{\text {in }}$ is the initial susceptibility of a specimen; $Q_{n}{ }^{\prime}$ is the Koenigsberger ratio of NRM; peak field strength listed in remarks column is that at which inclination of AFD remanent magnetization was taken; for other notations refer to Table 8 . 


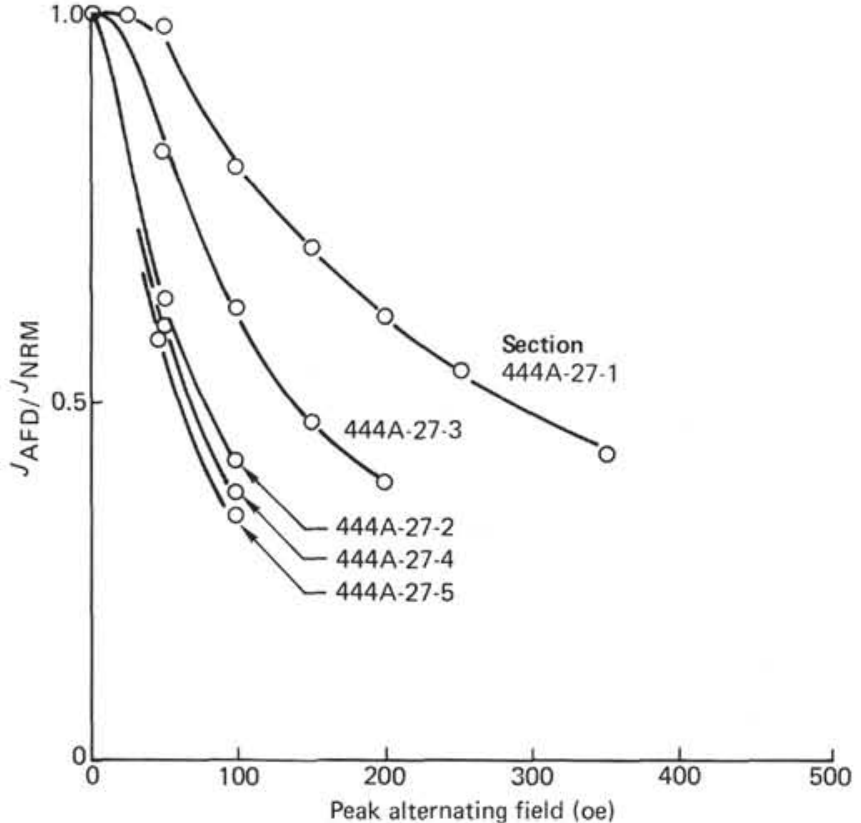

Figure 9. Stability of NRM with respect to AF demagnetization for basalts of Hole 444A. The horizontal axis represents peak alternating field decreasing to zero at a constant rate. $\mathrm{J}_{N R M}$ and $\mathrm{J}_{A F D}$ are intensities of NRM and AF-demagnetized remanent magnetization.
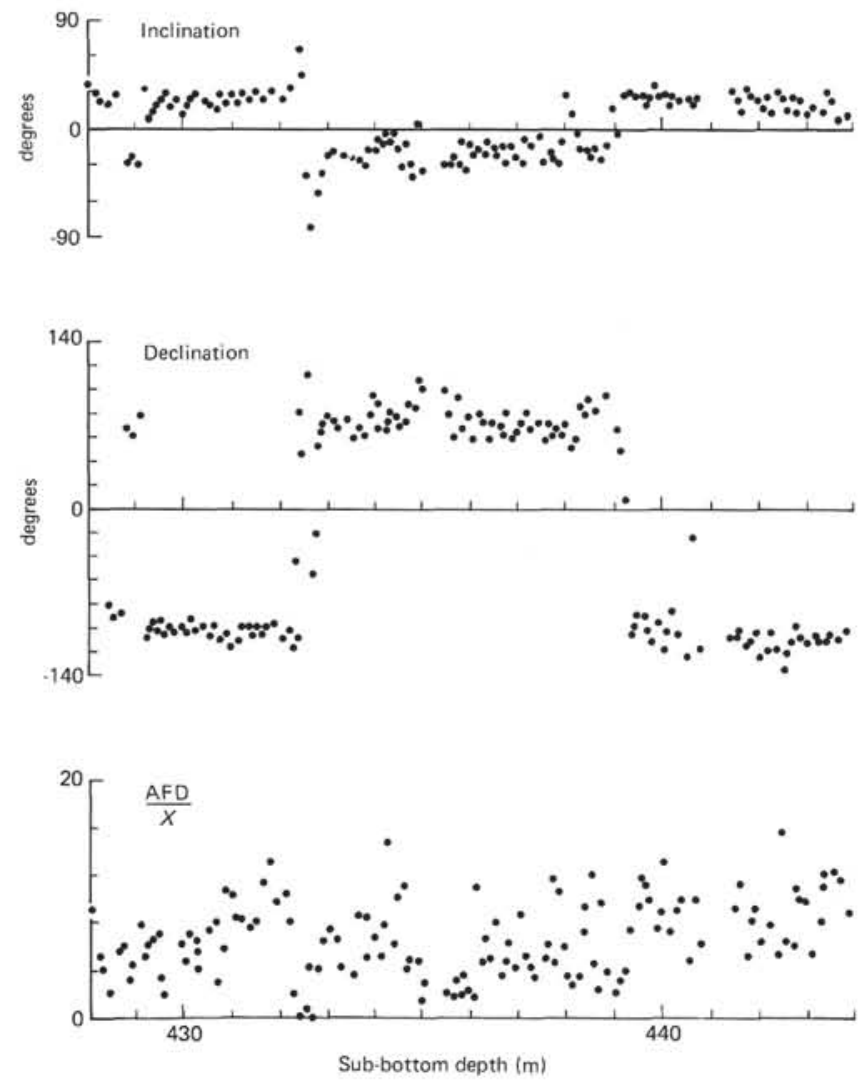

Figure 10. Change of NRM inclination, declination, and ratio of NRM (AF demagnetized at 150 oe) to initial susceptibility.
TABLE 10

Statistics of Paleomagnetism Results for Basalt Samples of Hole 444A

\begin{tabular}{llrc} 
Core Number & & 20 & $23-27$ \\
$\begin{array}{l}\text { Number of Samples } \\
\text { Inclination* }\end{array}$ & Mean & 58.7 & 12.3 \\
(degrees) & $\begin{array}{l}\text { Standard } \\
\text { Deviation }\end{array}$ & 4.6 & 2.7 \\
& Mean & 59.4 & 172.5 \\
$\begin{array}{l}\text { Intensity** } \\
\left(10^{-5} \text { gauss } / \mathrm{cm}^{3}\right)\end{array}$ & $\begin{array}{l}\text { Standard } \\
\text { Deviation }\end{array}$ & $42: 6$ & $134: 8$ \\
& & \\
\hline
\end{tabular}

geomagnetic field direction at the time of basalt formation). Occurrences of chocolate-colored clay at the surface of basalt layers, overgrowth of microfossils, a slight increase of carbon content, and decrease of water content of sediments observed above and between two basalt layers seem to favor heating of sediments. The most probable cause is an intrusion. The heat of intruded basalt would be dissipated in the heating of oceanic interstitial water, which would migrate upward, resulting in heating sediments above the intrusion. Heat would also be transferred by conduction and radiation, but the efficiency of convection (migration of water) is much higher (probably by one order of magnitude) than that of conduction or radiation. Therefore, sediment above the intrusion would receive much more heat than that below. As the temperature of the sediment was raised, there must have occurred a remagnetization of NRM, due to thermochemical reaction (thermochemical remanence), purely thermal agitation (partial thermoremanence), or hydromechanical turbation which realigned the original remanent magnetization with the geomagnetic field. If this is the case, both basaltic layers penetrated at this site must have been intruded after formation of the sedimentary layer above the basement rocks.

\section{Summary for Shikoku Basin, Sites $\mathbf{4 4 2}$ through $\mathbf{4 4 4}$}

Paleomagnetism data for sediment and basalt samples taken in the Shikoku Basin during Leg 58 are summarized as follows. At Sites 442 through 444, nine flow units are distinguishable by their AF-demagnetized and original NRM inclinations (hereinafter, "unit" means magnetic unit). On the basis of paleontological study, the basement of the whole area has been dated as middle Miocene, which assumes that all the lava units were formed during the same geologic age. Mean values of paleomagnetic data are listed in Table 11. For the sedimentary layers (Figure 11), the sedimentation rate was not constant during the last $15 \mathrm{~m} . \mathrm{y}$., and values are plotted against time without scale.

The results are summarized as follows:

1. Basement of the Shikoku Basin around Sites 442 through 444 remained at the same latitude or shifted slightly northward by not more than 4 degrees $(410 \mathrm{~km})$ during the last $20 \mathrm{~m} . \mathrm{y}$.

2. Scatter of NRM inclination of basalts is statistically of the same magnitude ( $\sim 40$ degrees), although the 
TABLE 11

Statistics for Stable NRM Inclination and Intensity of Basalt Samples obtained in the Shikoku Basin during Leg 58

\begin{tabular}{|c|c|c|c|c|c|c|c|}
\hline \multirow{2}{*}{\multicolumn{2}{|c|}{$\begin{array}{l}\text { Nine Units } \\
\text { Hole/Core }\end{array}$}} & \multicolumn{3}{|c|}{$\begin{array}{c}\text { Absolute } \\
\text { Inclination } \\
\text { (degrees) }\end{array}$} & \multicolumn{3}{|c|}{$\begin{array}{c}\text { Intensity } \\
\left(10^{-5} \text { gauss } / \mathrm{cm}^{3}\right)\end{array}$} \\
\hline & & \multirow{2}{*}{$\begin{array}{c}\begin{array}{c}\text { Number of } \\
\text { Samples }\end{array} \\
7\end{array}$} & \multirow{2}{*}{$\begin{array}{c}\text { Mean } \\
36.2\end{array}$} & \multirow{2}{*}{$\begin{array}{c}\begin{array}{c}\text { Standard } \\
\text { Deviation }\end{array} \\
4.2\end{array}$} & \multirow{2}{*}{$\begin{array}{c}\begin{array}{c}\text { Number of } \\
\text { Samples }\end{array} \\
8\end{array}$} & \multirow{2}{*}{$\begin{array}{l}\text { Mean } \\
208.5\end{array}$} & \multirow{2}{*}{$\begin{array}{c}\begin{array}{c}\text { Standard } \\
\text { Deviation }\end{array} \\
129.5\end{array}$} \\
\hline $442 \mathrm{~A}$ & $3-7$ & & & & & & \\
\hline $442 \mathrm{~B}$ & $8-14$ & 26 & 45.3 & 10.0 & 35 & 364.5 & 354.0 \\
\hline $442 B$ & $16-20$ & 6 & 40.7 & 13.2 & 7 & 326.9 & 144.5 \\
\hline 443 & $49-50$ & 7 & 30.6 & 2.0 & 7 & 651.5 & 186.7 \\
\hline 443 & $51-54$ & 15 & 41.7 & 2.3 & 15 & 481.9 & 288.2 \\
\hline 443 & $55-58$ & 15 & 66.2 & 7.5 & 15 & 271.3 & 212.7 \\
\hline 443 & $59-63$ & 26 & 50.2 & 4.5 & 26 & 71.1 & 29.3 \\
\hline 444 & 20 & 4 & 58.4 & 4.6 & 4 & 59.4 & 42.6 \\
\hline 444 & $23-27$ & 20 & 12.3 & 2.7 & 20 & 172.5 & 134.8 \\
\hline \multicolumn{2}{|c|}{ Overall } & - & 42.4 & 15.7 & - & 289.7 & - \\
\hline
\end{tabular}

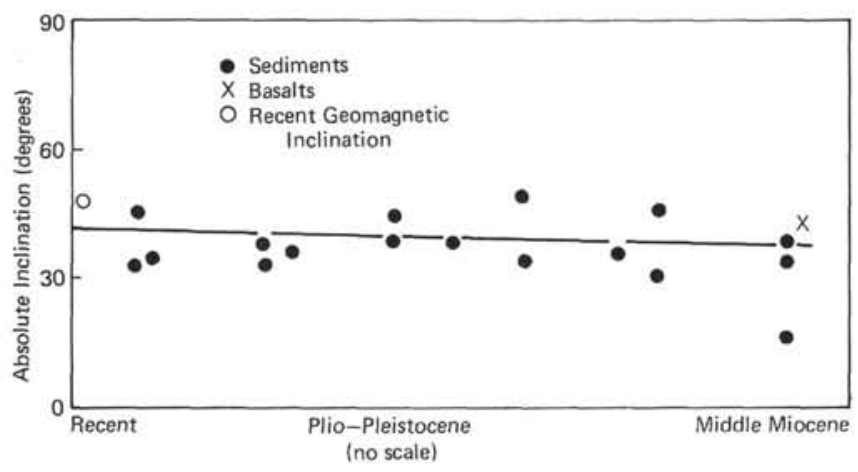

Figure 11. Mean values of NRM inclinations of sediments and basalts (Table 11) plotted against age. Age of basalts is assumed to be that of the bottom layer of sediments.

scatter within any basalt unit is much smaller. This implies that large wobbling or excursion-type motion of the geomagnetic dipole moment is common from the Miocene to the Holocene. A small secular variation is observed rarely in Quaternary basaltic rocks from central and northeast Pacific islands and from Hakone, Japan probably within a restricted geologic time span. The same type of inclination change is observed at several sites far from the present site (DSDP Legs 51, 52, and 55).

3. There is no positive correlation between NRM of basalts and the geomagnetic-anomaly pattern of this area. At Sites 442 and 443 , we found basalt layers carrying both normal and reversed polarities of NRM, and at Site 444 NRM is reversed, in contradiction with the sharp positive magnetic anomaly of this location. Therefore, it seems that the geomagnetic-field anomaly pattern at this area must be caused by NRM of (probably) basaltic layers seated under the ocean bottom deeper than several hundred meters. Thus, a more detailed study and construction of a new model for the magnetic ocean crust of this particular region are needed.

\section{PHYSICAL PROPERTIES}

Physical-properties measurements at Site 444 consisted in shear strength in sediments, and thermal con- ductivity, sonic velocity, porosity, density, and water content for sediments (Table 12) and basalts (Table 13). Techniques were the same as those outlined in the Site 442 report. Data from special 2-minute GRAPE counts on basalts are tabulated in Table 14. A grain density of $2.96 \mathrm{~g} / \mathrm{cm}^{3}$ was assumed for calculations of porosity and density.

Changes in shear strength of sediments in the upper 160 meters of the sedimentary sequence (Figure 12) are similar to those observed for the same depth interval at Sites 442 and 443 . Shear strength is low for the Pleistocene and Pliocene sediments constituting the upper 80 meters of the sequence. Shear strength increases in the late-Miocene sediments, unit III, between 83.5 and 168.1 meters. The linear relationship between shear strength and depth for this unit is:

$$
\tau=-4.86+0.06 z
$$

where $\tau$ equals shear strength and $z$ equals depth. The correlation coefficient is 0.94 .

The average thermal conductivity of Site 444 sediments is $2.32 \mathrm{mcal} / \mathrm{cm}-\mathrm{s}-{ }^{\circ} \mathrm{C}$, with a range of 1.989 to $2.581 \mathrm{mcal} / \mathrm{cm}-\mathrm{s}-{ }^{\circ} \mathrm{C}$. No systematic variation of sediment thermal conductivity with depth was observed (Figure 13). Thermal conductivity increases to an average value of $3.57 \mathrm{mcal} / \mathrm{cm}-\mathrm{s}^{\circ}{ }^{\circ} \mathrm{C}$ in the lower basalt unit. The range of conductivity is 3.33 to $3.83 \mathrm{mcal} / \mathrm{cm}$ $s-{ }^{\circ} \mathrm{C}$.

Figure 14 shows thermal conductivities of Hole 444A basalts as a function of porosity and includes the relationship derived for Site 443. The conductivities of Hole $444 \mathrm{~A}$ basalts are lower for a given porosity than the conductivity values from Site 443 basalts and do not fit the conductivity-porosity relationship established for Site 443 (see Site 443 report). The reason for this discrepancy is unclear. A significant change in the mineralogy of the basalts at this site could change the thermal conductivity. An increase in feldspar content, for instance, would reduce the thermal conductivity.

Sonic velocities in sediments vary little to a depth of about 225 meters (Figure 15). The average velocity for this interval is $1.53 \mathrm{~km} / \mathrm{s}$, similar to the average velocity for sediments from Sites 442 and 443 . Sonic velocities increase to values greater than $2.8 \mathrm{~km} / \mathrm{s}$ below 225 meters. A high-velocity basalt unit (about $5.0 \mathrm{~km} / \mathrm{s}$ ) beneath the sedimentary material was drilled. The higher-velocity sediment and the basalt unit certainly can be an acoustic reflector and appear as acoustic basement at this site. Christensen et al. (1973) noted that consolidated deep-sea sediments can be characterized by high sonic velocities and, furthermore, can be confused with the top of oceanic crustal basement. This was the case at Site 444, as sediments were recovered below the basalt unit and a thicker basalt unit, apparently basement, was penetrated below that.

Velocities in the uppermost portion of the deeper basalt unit are low, but increase to values of 5.4 to 5.6 $\mathrm{km} / \mathrm{s}$ within 5 to 10 meters of the top of the unit (Figure 16). The average sonic velocity in Hole $444 \mathrm{~A}$ basalts is $5.16 \mathrm{~km} / \mathrm{s}$, and the range is 4.25 to $5.60 \mathrm{~km} / \mathrm{s}$. The 
TABLE 12

Summary of Physical Properties of Sediments, Site 444

\begin{tabular}{|c|c|c|c|c|c|c|c|}
\hline $\begin{array}{c}\text { Sample } \\
\text { (interval in } \mathrm{cm} \text { ) }\end{array}$ & Lithology & $\begin{array}{l}\text { Sonic } \\
\text { Velocity } \\
(\mathrm{km} / \mathrm{s})\end{array}$ & $\begin{array}{c}\text { Thermal } \\
\text { Conductivity } \\
\text { (mcal/cm-s- }{ }^{\circ} \mathrm{C} \text { ) }\end{array}$ & $\begin{array}{c}\text { Shear } \\
\text { Strength } \\
\left(\times 10^{-5} \text { dynes } / \mathrm{cm}^{2}\right)\end{array}$ & $\begin{array}{l}\text { Wet-Bulk } \\
\text { Density } \\
\left(\mathrm{g} / \mathrm{cm}^{3}\right)\end{array}$ & $\begin{array}{l}\text { Porosity } \\
(\%)\end{array}$ & $\begin{array}{l}\text { Water } \\
\text { Content } \\
(\%)\end{array}$ \\
\hline $444-2-2,5-8$ & mud & - & - & 0.05 & - & - & - \\
\hline $2-3,56-59$ & $"$ & - & - & 0.096 & - & - & - \\
\hline $2-4,16-26$ & $"$ & 1.503 & 2.444 & 0.096 & 1.43 & 76.01 & 54.30 \\
\hline $2-4,144-146$ & $"$ & - & - & - & 1.47 & 73.47 & 51.19 \\
\hline $3-1,50-53$ & $"$ & - & - & 0.096 & - & - & - \\
\hline $3-2,44-54$ & $"$ & 1.520 & 2.472 & - & 1.50 & 72.73 & 49.79 \\
\hline $3-3,50-53$ & ", & - & - & 0.48 & - & - & - \\
\hline $4-1,49-52$ & $"$ & - & - & 0.86 & - & - & - \\
\hline $4-2,99-109$ & $"$ & 1.561 & 2.381 & - & 1.42 & 74.41 & 53.71 \\
\hline $4-3,106-116$ & $"$ & 1.426 & 2.489 & - & 1.49 & 72.15 & 49.59 \\
\hline $4-4,4-7$ & $"$ & - & - & 0.048 & - & - & - \\
\hline $4-4,44-47$ & $"$ & - & - & 0.096 & - & - & - \\
\hline $5-1,72-75$ & $"$ & - & - & 0.29 & - & - & - \\
\hline $5-2,72-75$ & $"$ & - & - & 0.19 & 1.47 & 76.05 & 53.01 \\
\hline $5-3,72-75$ & $"$ & - & - & 0.56 & - & - & - \\
\hline $5-4,72-82$ & $"$ & 1.492 & 2.447 & 0.07 & 1.46 & 73.69 & 51.87 \\
\hline $7-1,29-32$ & $"$ & - & - & 0.77 & - & - & - \\
\hline $7-2,97-100$ & $"$ & - & - & 0.17 & - & - & - \\
\hline $7-3,36-39$ & $"$ & - & - & 0.18 & - & - & - \\
\hline $7-5,144-150$ & $"$ & - & - & - & 1.60 & 68.85 & 44.18 \\
\hline $7-5,144-150$ & $"$ & - & - & - & 1.58 & 67.56 & 43.95 \\
\hline $9-1,40-50$ & " & 1.580 & 2.292 & 0.29 & 1.35 & 81.63 & 62.01 \\
\hline $10-2,77-89$ & $"$ & 1.526 & 2.253 & 0.38 & 1.42 & 78.68 & 56.78 \\
\hline $444 \mathrm{~A}-2-3,85-99$ & $"$ & 1.521 & 2.225 & 0.48 & 1.50 & 67.85 & 46.46 \\
\hline $3-3,79-94$ & $"$ & 1.514 & 2.294 & 1.15 & 1.51 & 74.17 & 50.37 \\
\hline $3-5,29-32$ & $"$ & - & - & 2.01 & - & - & - \\
\hline $6-3,48-58$ & Siliceous mud & 1.471 & 2.308 & 3.26 & 1.42 & 75.71 & 54.44 \\
\hline $6-3,51-54$ & " & 1.521 & - & - & - & - & - \\
\hline $6-4,140-150$ & $"$ & - & - & - & 1.42 & 74.56 & 53.78 \\
\hline $7-1,68-78$ & $"$ & - & 2.372 & 3.45 & 1.42 & 77.90 & 56.15 \\
\hline $8-1,74-85$ & $"$ & 1.511 & 2.344 & 4.02 & 1.43 & 77.65 & 55.65 \\
\hline $9-3,140-150$ & $"$ & - & - & - & 1.46 & 72.24 & 50.84 \\
\hline $9-4,8-12$ & $"$ & - & - & 2.11 & 1.41 & 76.72 & 55.63 \\
\hline $9-4,58-68$ & " & 1.517 & 2.281 & - & - & - & - \\
\hline $10-2,67-77$ & mud & 1.544 & 1.989 & 7.66 & 1.55 & 66.79 & 44.08 \\
\hline $11-1,48-58$ & " & 1.520 & 2.253 & 2.68 & 1.46 & 69.52 & 48.92 \\
\hline $11-2,48-58$ & $"$ & 1.570 & 2.253 & 2.72 & 1.57 & 63.29 & 41.21 \\
\hline $11-3,48-51$ & $"$ & - & - & 6.80 & - & - & - \\
\hline $11-4,65-68$ & $"$ & - & - & 6.61 & - & - & - \\
\hline $12-1,41-43$ & $"$ & - & - & 2.20 & - & - & - \\
\hline $12-1,85-88$ & $"$ & - & - & 2.20 & - & - & - \\
\hline $12-2,70-80$ & $"$ & 1.510 & 2.450 & 2.97 & 1.49 & 73.19 & 50.41 \\
\hline $12-3,14-17$ & $"$ & - & - & 3.83 & - & - & - \\
\hline $13-1,63-73$ & mudstone & 1.561 & 2.581 & 2.68 & 1.56 & 72.56 & 47.78 \\
\hline $13-3,53-56$ & " & - & - & 8.24 & - & - & - \\
\hline $14-3,32-42$ & " & 1.555 & 2.092 & - & 1.41 & 77.02 & 55.96 \\
\hline $14-3,90-93$ & $"$ & - & - & - & 1.51 & 73.29 & 49.82 \\
\hline $15-2,40-50$ & " & 1.581 & 2.206 & - & 1.52 & 66.13 & 44.48 \\
\hline $16-1,44-47$ & " & 1.657 & - & - & 1.44 & 73.99 & 51.40 \\
\hline $16-2,140-150$ & $"$ & - & - & - & 1.51 & 73.53 & 48.56 \\
\hline $16-3,127-141$ & $"$ & - & 2.903 & - & 1.68 & 55.64 & 33.12 \\
\hline $17-1,0-3$ & claystone & 3.152 & - & - & - & - & - \\
\hline $17-1,25-28$ & , & 2.925 & - & - & - & - & - \\
\hline $17-1,25-28$ & " & $2.491^{\mathrm{a}}$ & - & - & - & - & - \\
\hline $21-1,60-63$ & $"$ & 1.592 & - & - & - & - & - \\
\hline $21-1,135-150$ & ash & - & - & - & 1.54 & 62.52 & 41.72 \\
\hline $21-1,135-150$ & $"$ & - & - & - & 1.48 & 71.92 & 48.59 \\
\hline $21-2,93-95$ & siliceous mudstone & - & - & - & 1.53 & 65.75 & 44.00 \\
\hline $22-1,15-18$ & claystone & 1.725 & - & - & - & - & - \\
\hline $22-2,91-93$ & $"$ & - & - & 5.17 & - & - & - \\
\hline
\end{tabular}

${ }^{\mathrm{a}}$ Propagation direction parallel to core axis. 
TABLE 13

Summary of Physical Properties of Igneous Rocks, Hole 444A

\begin{tabular}{ccccccc}
\hline $\begin{array}{c}\text { Sample } \\
\text { (interval in cm) }\end{array}$ & $\begin{array}{c}\text { Piece } \\
\text { No. }\end{array}$ & $\begin{array}{c}\text { Sonic } \\
\text { Velocity } \\
(\mathrm{km} / \mathrm{s})\end{array}$ & $\begin{array}{c}\text { Thermal } \\
\text { Conductivity } \\
\left(\mathrm{mcal} / \mathrm{cm}_{-5}{ }^{\circ} \mathrm{C}\right)\end{array}$ & $\begin{array}{c}\text { Wet-Bulk } \\
\text { Density } \\
\left(\mathrm{g} / \mathrm{cm}^{3}\right)\end{array}$ & $\begin{array}{c}\text { Grain } \\
\text { Density } \\
\left(\mathrm{g} / \mathrm{cm}^{3}\right)\end{array}$ & $\begin{array}{c}\text { Porosity } \\
(\%)\end{array}$ \\
\hline $444 \mathrm{~A}-20-1,45-48$ & $2 \mathrm{~b}$ & 5.032 & - & - & - & - \\
$23-2,87-97$ & 14 & 4.250 & 3.400 & - & - & - \\
$24-1,62-72$ & $8 \mathrm{a}$ & 5.063 & 3.459 & - & - & - \\
$24-2,30-40$ & 2 & 5.419 & 3.469 & - & - & - \\
$25-1,8-11$ & 1a & 5.460 & - & 2.82 & 2.94 & 6.19 \\
$25-1,45-55$ & If & - & 3.831 & - & - & - \\
$25-2,35-45$ & 1d & - & 3.558 & - & - & - \\
$25-3,40-50$ & 1c & - & 3.597 & - & - & - \\
$25-3,92-102$ & 1c & - & 3.611 & - & - & - \\
$26-1,65-75$ & 1a & - & 3.675 & - & - & - \\
$26-2,4-14$ & 1a & - & 3.769 & - & - & - \\
$26-2,110-120$ & Ic & - & 3.517 & - & - & - \\
$26-3,66-76$ & 2 & - & 3.422 & - & - & - \\
$27-1,90-100$ & 3b & - & 3.333 & - & - & - \\
$27-2,90-100$ & 1d & - & 3.675 & - & - & - \\
$27-4,3-6$ & 1a & 5.602 & - & 2.87 & 2.98 & 5.36 \\
$27-4,45-55$ & 3a & - & 3.675 & - & - & - \\
$27-5,39-49$ & Sb & - & 3.594 & - & - & - \\
\hline
\end{tabular}

TABLE 14

Wet-Bulk Density and Porosity from 2-Minute GRAPE Counts, Igneous Rocks, Hole $444 A^{a}$

\begin{tabular}{|c|c|c|c|}
\hline $\begin{array}{c}\text { Sample } \\
\text { (interval in } \mathrm{cm} \text { ) }\end{array}$ & $\begin{array}{l}\text { Piece } \\
\text { No. }\end{array}$ & $\begin{array}{l}\text { Wet-Bulk } \\
\text { Density } \\
\left(\mathrm{g} / \mathrm{cm}^{3}\right)\end{array}$ & $\begin{array}{c}\text { Porosity } \\
(\%)\end{array}$ \\
\hline $444 \mathrm{~A}-20-1,27-29$ & 1 & 2.59 & 19.10 \\
\hline $20-1,45-47$ & $2 b$ & 2.60 & 18.89 \\
\hline $20-1,71-73$ & 5 & 2.60 & 18.50 \\
\hline $20-2,85-87$ & lc & 2.56 & 20.90 \\
\hline $20-2,88-90$ & $1 \mathrm{c}$ & 2.69 & 13.74 \\
\hline $20-4,46-48$ & 1 & 2.65 & 15.92 \\
\hline $23-2,87-89$ & 14 & 2.56 & 20.82 \\
\hline $23-2,138-140$ & $22 \mathrm{a}$ & 2.79 & 8.97 \\
\hline $24-1,73-75$ & $8 \mathrm{a}$ & 2.79 & 8.73 \\
\hline $24-2,30-32$ & 2 & 2.80 & 8.46 \\
\hline $24-3,21-23$ & 1 & 2.85 & 5.88 \\
\hline $25-1,49-51$ & If & 2.90 & 3.19 \\
\hline $25-2,50-52$ & le & 2.84 & 6.41 \\
\hline $25-2,109-111$ & $1 \mathrm{~h}$ & 2.88 & 4.42 \\
\hline $25-3,44-46$ & $1 \mathrm{c}$ & 2.81 & 7.75 \\
\hline $25-3,92-94$ & le & 2.82 & 7.15 \\
\hline $25-4,38-40$ & 2 & 2.89 & 3.75 \\
\hline $26-1,65-67$ & $3 c$ & 2.87 & 4.73 \\
\hline $26-2,5-7$ & $1 \mathrm{a}$ & 2.86 & 5.36 \\
\hline $26-2,111-113$ & $1 \mathrm{c}$ & 2.92 & 2.20 \\
\hline $26-3,68-70$ & 2 & 2.84 & 6.06 \\
\hline $26-4,63-65$ & 5 & 2.85 & 5.73 \\
\hline $27-1,90-92$ & $3 b$ & 2.81 & 7.84 \\
\hline $27-2,93-95$ & $1 d$ & 2.82 & 7.51 \\
\hline $27-3,43-45$ & $1 \mathrm{c}$ & 2.89 & 3.48 \\
\hline $27-4,83-85$ & $3 c$ & 2.81 & 7.58 \\
\hline $27-5,39-41$ & $5 b$ & 2.87 & 4.75 \\
\hline
\end{tabular}

higher velocities, however, are more representative of the unit. Density estimates from 2-minute GRAPE counts are also shown in Figure 16. Low densities characterize the upper portion of the basalt unit and are caused by numerous vesicles filled with clay. The average density for the remainder of the unit, however, is $2.85 \mathrm{~g} / \mathrm{cm}^{3}$.

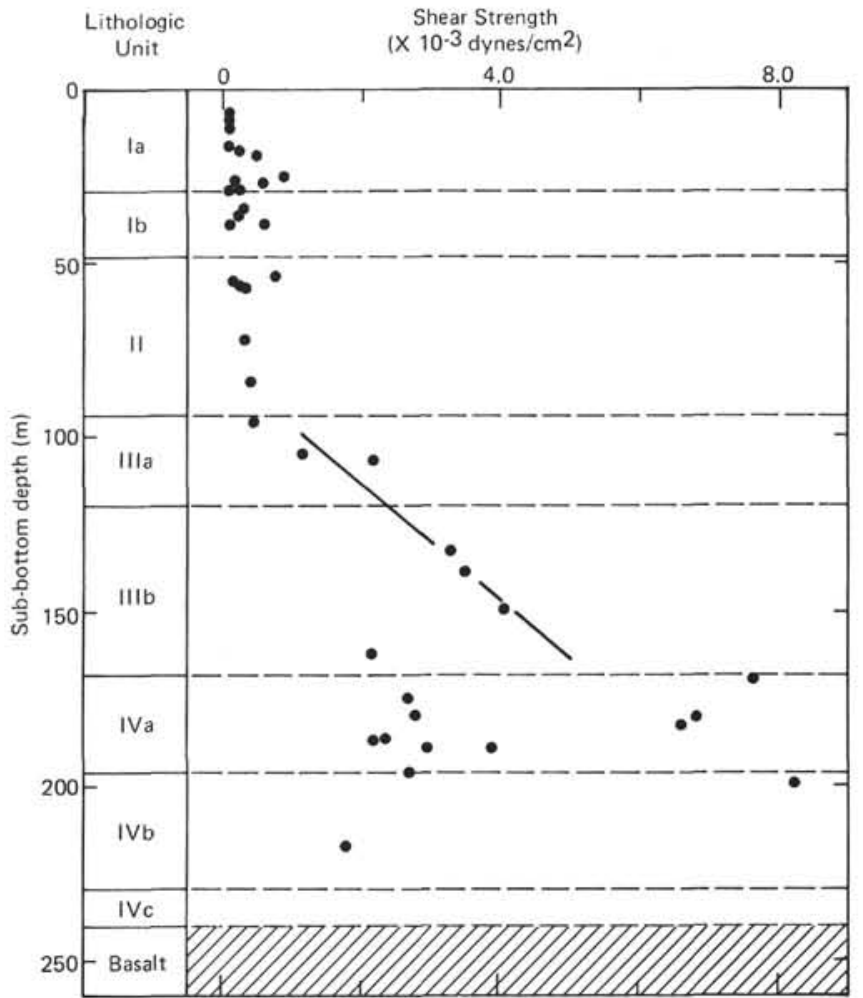

Figure 12. Shear strength versus depth for Site 444 sediments.

\section{CORRELATION OF GEOPHYSICAL DATA WITH DRILLING RESULTS}

\section{Introduction}

Site 444 is on seismic-reflection profile KH77-1:7705111835 obtained by the R/V Hakuko-Maru (Figure 1). The site is on the eastern shoulder of a positive magnetic anomaly with moderate amplitude (120 gammas peak to trough). It is situated in a NNW-SSE-elongated moat west of an escarpment of basement which may have trapped thick sediments covering the eastern margin of the basin. Sonobuoy observation was not made, as our attempt at sonobuoy survey when leaving the site was prevented by bad weather and sea conditions.

\section{Sonic Velocity and Sub-bottom Depth}

Seismic-reflection profiles taken underway when approaching and leaving the site and the aforementioned data show a layering of semi-transparent sediment with two-way normal time of about 0.28 seconds overlying the acoustic basement. Shipboard measurement of the sonic velocity of sediment recovered indicated that its $V_{P}$ is about $1.55 \mathrm{~km} / \mathrm{s}$ on the average throughout the cores, except for a 12-meter-thick layer of claystone $\left(V_{P}\right.$ $=3.1$ ) overlying the first basalt encountered at this site. Thickness of sediment thus estimated is 217 meters, which is consistent with the depth of the claystone with a high velocity (228 meters), but appreciably higher than the depths of basalt layers recovered. 


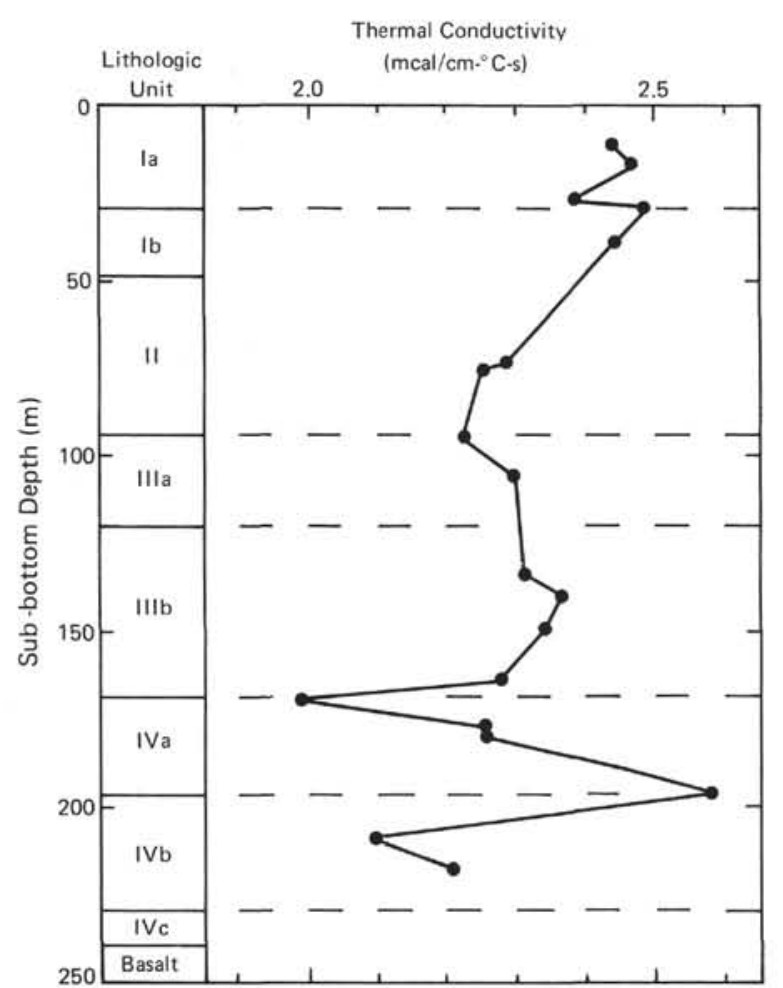

Figure 13. Thermal conductivity versus depth for Site 444 sediments.

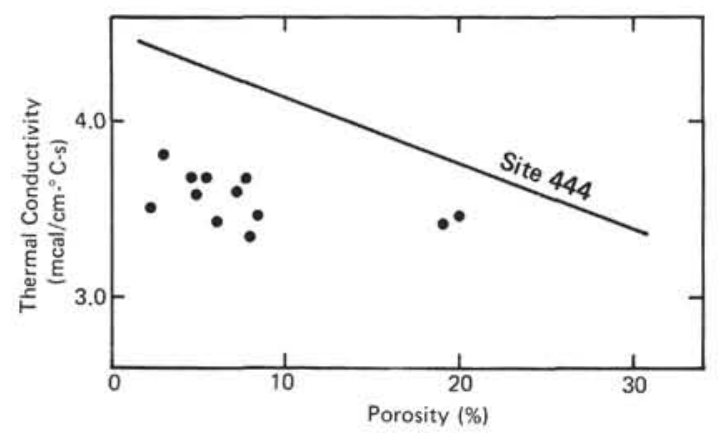

Figure 14. Thermal conductivity versus porosity for Site 444 igneous rocks.

\section{Magnetic Anomaly, Paleomagnetism, and Paleontological Age}

Natural remanent magnetization of rocks recovered at this site is all reversed, in contrast to the observed positive magnetic anomaly. This discrepancy cannot be explained by the skewness of the anomaly due to the angle of anomaly trend from the meridian line. Thicker and possibly more strongly magnetized layers with normal magnetic polarity should be located below this hole.

The most remarkable aspect of magnetism of basalts recovered at Sites 442 through 444 in the Shikoku Basin is the independence of polarity from the magnetic anomaly observed at each site. As shown in Figure 17, a succession of alternating normal and reversed polarities of natural remanent magnetization was found in the layers about 130 to 180 meters thick at Sites 442 and

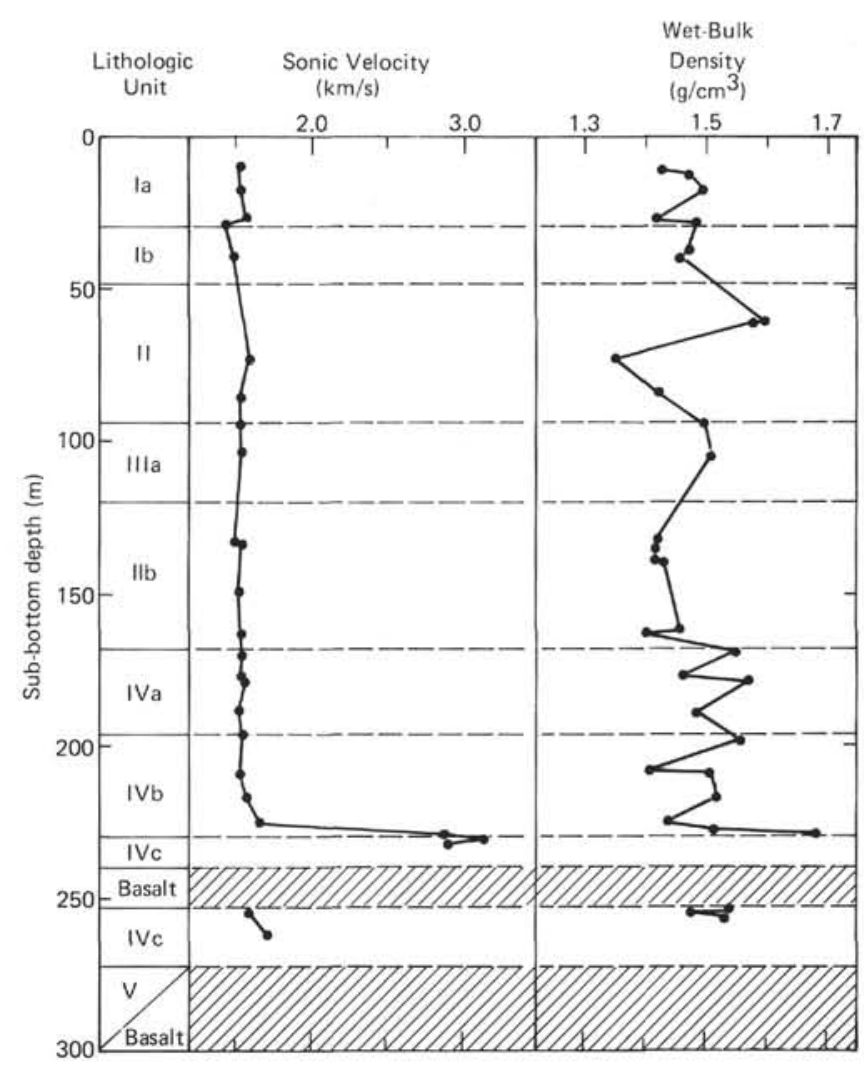

Figure 15. Sonic velocity and wet-bulk density versus depth for Site 444 sediments. Igneous rocks are shown by the cross-hatched pattern.

443. Only reversed polarity was found in the 75 meters of basalts recovered at Site 444. Although these sites are slightly off the crest of the positive anomaly, the blocksource model of linear magnetic anomaly indicates that magnetization beneath these sites must be normal as far as the model obtains.

Occurrence of both normal and reversed polarities at the same sites indicates that duration of volcanism forming these layers was not short (probably more than 0.2 m.y. to form the 100 -meter layer at Site 443 ), and may have been intermittent, with some period of cessation. Therefore, ages of the oldest sediments overlying or interlayered with the basalt layers will not provide ages of the major crustal formation by spreading. It seems likely that the uppermost layers of basalt were formed either by later eruptions or by off-ridge intrusions sometime after spreading from the crest of the ridge. The difference in polarity and inclination of magnetization in samples among these sites imply that the later activity was not simultaneous in this basin.

The following implications pertain to the origin of linear magnetic anomalies in the Shikoku Basin:

1. The uppermost basalt layers, at least a few hundred meters thick, are not the primary source of the observed magnetic anomalies. Uniformly magnetized layers causing the linear magnetic anomalies should be deep-seated, beneath the layers penetrated by drilling.

2 . The magmatic activity forming the uppermost pillow lavas and sills was not synchronous with crustal 


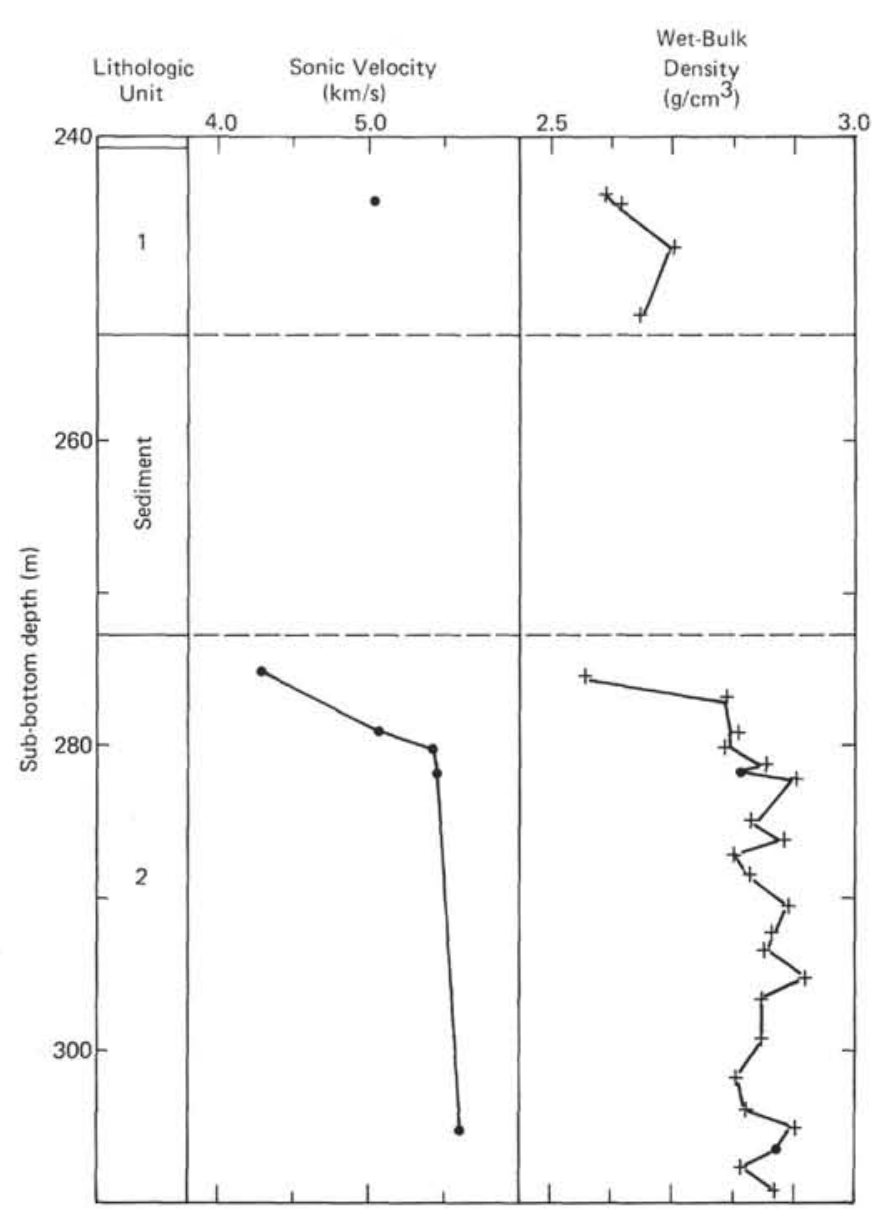

Figure 16. Sonic velocity and wet-bulk density versus depth for the igneous rock units cored at Site 444.

spreading in the basin, and possibly much later phenomena, with several intervals of cessation of volcanism.

3 . The exact age of spreading and mode of spreading cannot be given by the oldest sediments recovered by the present drilling. The oldest sediment ages provide the minimum ages of crust formation. Spreading must be older than these ages.

\section{SUMMARY AND CONCLUSIONS}

\section{Summary}

The stratigraphic succession at Site 444 consists of seven lithologic units, five of which are sedimentary and range in age from middle Miocene to Quaternary, and two of which are basalt. Both basalt units are diabase sills; one intrudes middle-Miocene mudstones.

The total penetration at Site 444 was 310.0 meters, and both a sedimentary section and the top of an igneous section were recovered. The depth of penetration into basalt was 37.3 meters.

The interpretation of relative depth of deposition of the sedimentary units at Site 444 is shown in Figure 18. The sediment contents suggest that during the depositional history at Site 444 the depositional surface fluctuated both above and below the CCD, but well below the lysocline. Deposition was below the CCD during deposition of the hemipelagic clays of unit II and the

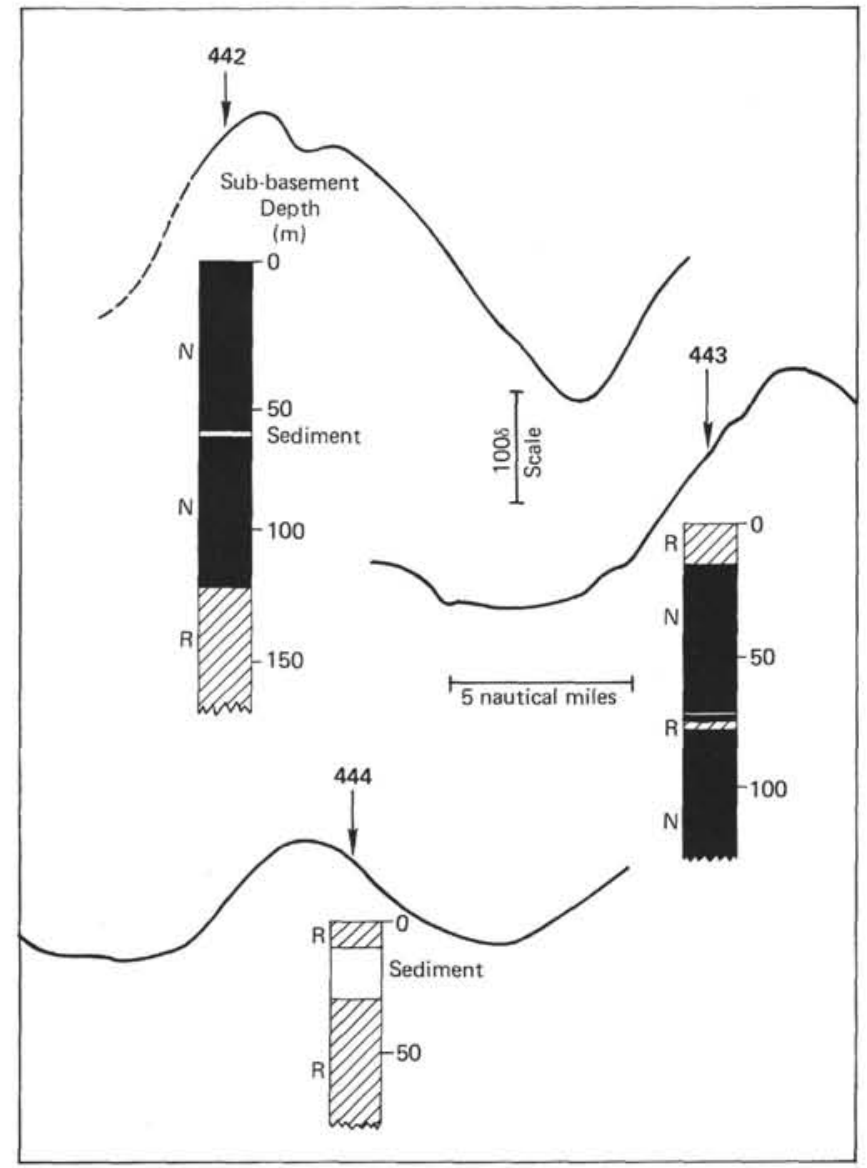

Figure 17. Relation between the polarities of natural remanent magnetization of basalts and the magnetic anomaly at each site in the Shikoku Basin.

basal part of unit Ib. The remaining units were deposited slightly above the CCD.

The dominant mode of sedimentation at Site 444 was the deposition of hemipelagic clays. However, other lithologic components are also present, and are more prevalent than at Sites 442 and 443 . The ash content at Site 444 is much higher than the other sites, and both andesitic and basaltic ash occur. The presence of clayey nannofossil oozes and thin layers of clayey radiolarian oozes at Site 444 indicates periods of slight increases in biogenic pelagic sedimentation. Such clayey biogenic pelagic interbeds are rare at Site 443 and absent at Site 442. This indicates that Site 444 was closer to volcanic sources (possibly local seamounts, the Iwo Jima Ridge or the Bonin Islands) or more favorably located with respect to prevailing wind directions than the other sites. Site 444 was more distal also with respect to sources of hemipelagic materials, thus permitting better preservation of clayey biogenic oozes in the sedimentary record and accounting for a thinner succession of hemipelagic sediment.

The sediment accumulation rate at Site 444 is generally moderate throughout, the highest rates occurring during the Pleistocene and the early middle Miocene, when there was an increase in the volume of ash. These slightly higher rates are coincident with known circum-Pacific 


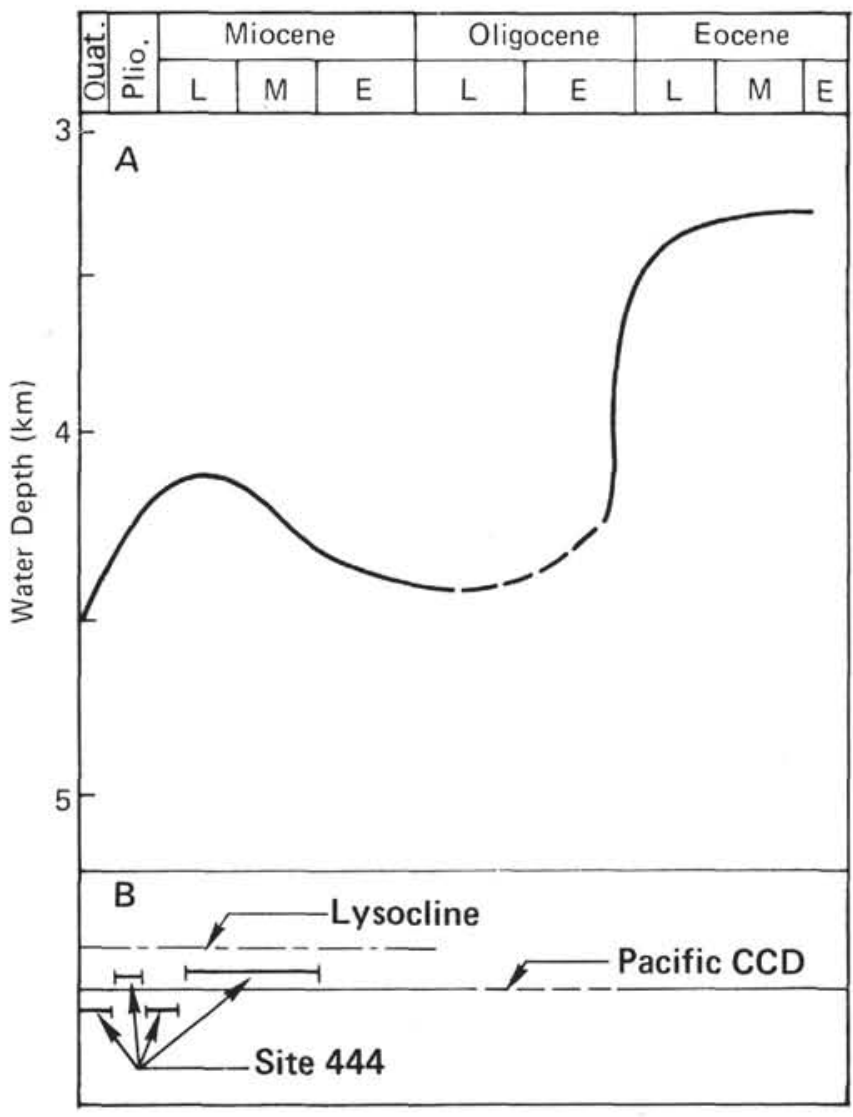

Figure 18. A. General curve showing estimated water depth of CCD in Pacific Ocean lafter van Andel et al., 1975, p. 47, fig. 29). B. Relative depth of deposition at Site 444 compared to CCD curve for Pacific Ocean.

volcanic episodes (Kennett et al., 1975). The remaining rates for the hemipelagic interval are far lower than at Sites 442 and 443 . These lower rates reflect the distal location of Site 444 with respect to known sources, and are partly controlled by preservation of biogenic pelagic sediments. The sediment accumulation rate for unit $\mathrm{V}$ pelagic red clay is exceedingly low.

Organic-carbon content decreases regularly to a depth of 100 meters and is constant below that depth. A higher organic-carbon content occurs immediately below the basalt sill in unit IVc. The vertical decrease in organic-carbon content may owe its origin to continuing bacterial degradation of organic material in the sediments until the nutritional value is exhausted. This bacterial degradation appears to require about 6 or 7 m.y., after which time the organic-carbon content remains constant. An anomalously high organic-carbon content occurs immediately below the basaltic sill, indicating that there the intrusion occurred before bacterial degradation was completed. The basalt intrusion pyrolyzed the remaining organic material, rendering the residue unusable by the bacteria. These thermal effects appear to have preserved completely the organic-carbon content for 10 meters below the sediment. A comparison of the content of pyrolyzed carbon with the bacteri- al degradation curve provides an estimate of the age of the basalt intrusion at 13 to 14 m.y. A K-Ar age determination on this upper sill yielded an age of $14.2 \pm 2.1$ m.y. (McKee and Klock, this volume).

The $p \mathrm{H}$ of the sediment averages 7.64, the alkalinity averages $3.12 \mathrm{meq} / \mathrm{kg}$, the salinity averages 35.9 per mill, and the chlorinity averages 19.2 per mill.

Physical properties show several changes that are consistent with observations made at Sites 442 and 443 . The sonic velocity of the sediments averages $1.53 \mathrm{~km} / \mathrm{s}$, whereas for the basalt it averages $5.16 \mathrm{~km} / \mathrm{s}$. Average density for the sediment is $1.51 \mathrm{~g} / \mathrm{cm}^{3}$, and for the basalt $2.85 \mathrm{~g} / \mathrm{cm}^{3}$. Porosity for the sediments ranges from 56 to 82 per cent, and in the basalt from 2 to 21 per cent. The shear strength of the sediments ranges from 0.1 to 8.2 dynes $/ \mathrm{cm}^{2}$. At Site 444 , a correlation between shear strength and depth can be extrapolated from a depth of 80 to 160 meters, but the data are too variable below that depth to define any additional trends. The correlation coefficient is 0.94 for that interval.

The basalts are mostly olivine tholeiites and consist of an aphyric basalt and diabase sill which intrudes unit IVc, and a massive unit of plagioclase phyric basalt and diabase below the sedimentary column. The age of the oldest sediment immediately above the second basalt unit is 14 to 15 m.y., whereas the estimated age of intrusion of the basalt sill of unit 1 is estimated at 13 to 14 m.y. A K-Ar age determination on this upper sill yielded an age of $14.2 \pm 2.1$ m.y. (McKee and Klock, this volume). The massive basalts of Unit 2 appear to be emplaced beneath a sedimentary cover, as indicated by the lack of pillows. Both basalt units appear to be younger than the start of sedimentation and probably indicate an episode of "off-ridge" volcanism in the Shikoku Basin that post-dates the youngest age of spreading, reported as 17 m.y. by Kobayashi and Isezaki (1976) and Kobayashi and Nakata (1977).

Paleomagnetism measurements show that Site 444 (and in conjunction with a re-plotting of data from the earlier sites, also Sites 442 and 443) was located approximately $500 \mathrm{~km}$ south of its present position at $15 \mathrm{Ma}$. That paleolatitude is in rough agreement with a known convergence rate of the Philippine plate into the Nankai trough of $3 \mathrm{~cm} / \mathrm{yr}$. The NRM intensities of the Site 444 basalts are lower than those of typical oceanic basalts. The basalt sill intruding unit IVc shows reversed magnetization with high absolute inclination, whereas the massive basalt beneath unit $\mathrm{V}$ shows reversed magnetization, with low values of inclination. The inclination of stable NRM of basalt and sediment immediately overlying it is nearly identical. The extraordinarily small scatter of inclination in the 20 meters of sediment overlying basalt suggests that the NRM of the sediment is not of normal depositional origin, but possibly is caused by thermal effects of basalts.

\section{CONCLUSIONS} 444:

Our data permit the following conclusions for Site

1. The age of the sediment immediately above the massive basalts, dated from fossils in the sediment re- 
covered from Core 23-2, is early middle Miocene (14-15 m.y.; Sphenolithus heteromorphus Zone of nannoplankton). This 15-m.y. biostratigraphic age is at variance with the age of magnetic anomaly 6A (23 m.y.) postulated by Kobayashi and Nakata (1977).

2. The age of the intrusive sill in unit IVc is estimated at 13 to $14 \mathrm{~m} . \mathrm{y}$. This age determination was made from extrapolations of organic-geochemistry data. A $\mathrm{K}-\mathrm{Ar}$ age determination by McKee and Klock (this volume) yielded an age of $14.2 \pm 2.1 \mathrm{~m} . \mathrm{y}$.

3. The depositional surface of sedimentation at Site 444 was slightly or well above the CCD, but below the lysocline for nearly the entire sedimentary history. Periods when deposition occurred below the CCD include the late Pleistocene and the latest Miocene. Poor preservation of a sparse fauna of foraminifers throughout the column clearly indicates that deposition occurred below the lysocline, although the occurrence of nannofossil ooze and chalk suggests local periods of deposition well above the CCD. Although the exact depth of deposition cannot be estimated, because no data exist concerning the elevation and fluctuations of the CCD in the Shikoku Basin through time, a depositional surface depth no less than 3800 meters is suggested, based on the general Pacific Ocean CCD curve of Van Andel et al. (1975).

4. Most of the sediment is hemipelagic. However, the relative volume of hemipelagic muds is less at Site 444 in comparison to Sites 442 and 443 , indicating that deposition occurred in a distal basin. The presence of interbedded clayey biogenic carbonate and clayey siliceous pelagic sediments confirms the reduced influx of hemipelagic sediment at this site. This fits the overall moderate rate of sedimentation determined for Site 444 . Distal Site 444 is on the western edge of an eastwardthickening clastic wedge recognized from seismic surveys by Murauchi and Asanuma (1974, 1977), shown in Figure 19, and from contouring of sediment thickness from seismic records by Karig (1975, p. 862, fig. 3 ). This clastic wedge thickens toward the Iwo Jima Ridge, which probably was the source of the hemipelagic sediments.

5. The ash content of the sediments at Site 444 is much higher than at the other two sites. The ash is both andesitic and basaltic, suggesting derivation from at least two different volcanic sources, which may include local seamounts or the active volcanic front of the Iwo Jima Ridge.

6. The basalts are olivine tholeiites and are equivalent to oceanic basalts in composition. They occur as an intrusive sill in unit IVc and below the sedimentary column as a massive unit which is probably sill-like, having been extruded below a thin sediment cover. The basalts are younger than spreading cessation, (assumed to be Ma). The basalt sill is estimated to be 13 to $14 \mathrm{~m} . \mathrm{y}$. old. These basalts appear to represent an off-ridge episode of volcanism younger than basin spreading. This off-ridge volcanism may have originated from local seamounts, unmapped fissure systems, or possibly some of the basin transform faults.

7. Statistical averages of magnetic inclination in sediments of different ages show a northward drift of the Shikoku Basin by nearly $500 \mathrm{~km}$ over the past $15 \mathrm{~m} . \mathrm{y}$.

8. Reversed polarity of natural remanent magnetization of basalt samples indicates that the basalt layer penetrated at Site 444 is not the primary source of the observed (positive) magnetic anomaly. The magnetic source body may be located well below the depth of penetration at Site 444 and is possibly much older than the recovered basalts.

\section{REFERENCES}

Andrews, J. E., Packham, G. H., et al., 1975. Init. Repts. $D S D P, 30$ : Washington (U. S. Govt. Printing Office).

Berggren, W. A., 1972. A cenozoic time-scale-some implications for regional geology and paleogeography. Lethaia, 5, 195-215.
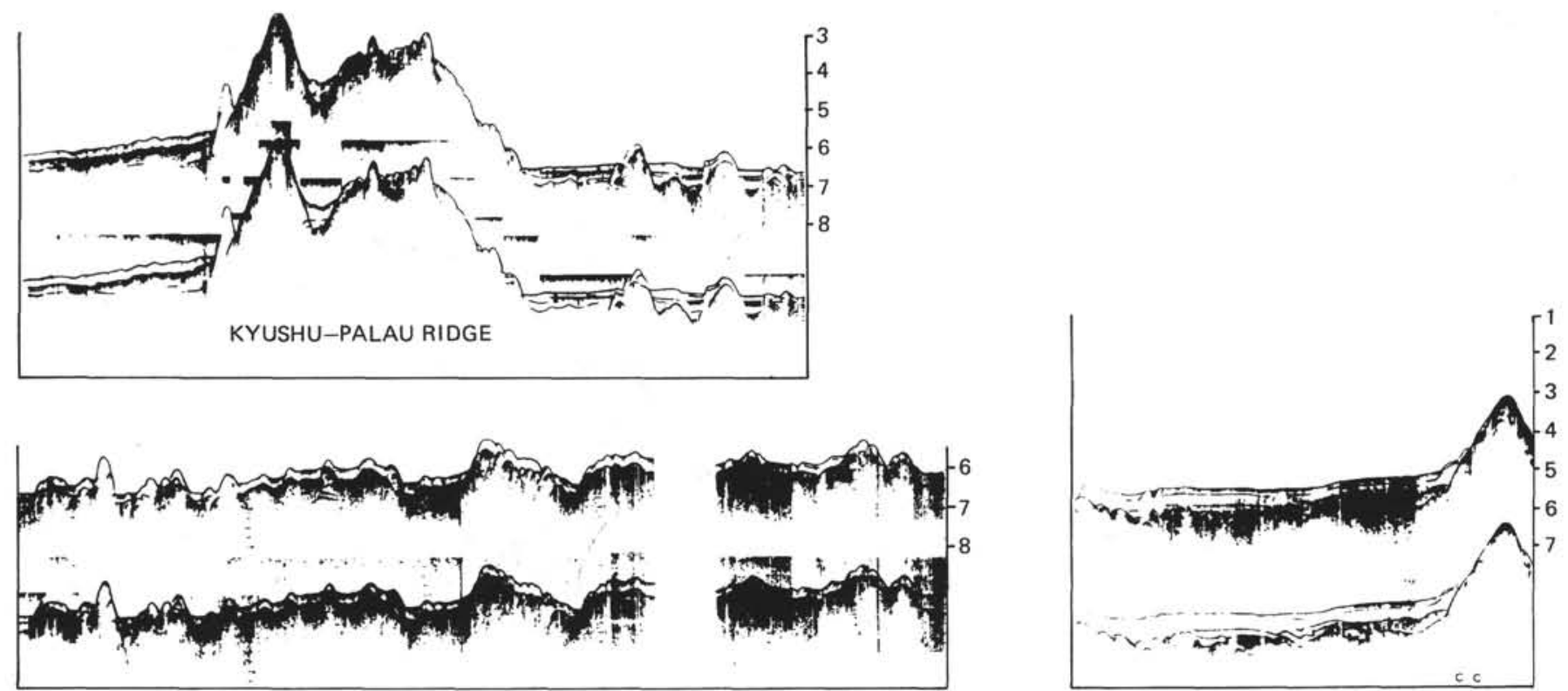

Figure 19. Seismic section showing clastic wedges, Shikoku Basin (from Marauchi and Asanuma, 1977, pp. 53-54). 
Berggren, W. A., and Van Couvering, J. A., 1974. The late Neogene biostratigraphy, geochronology and paleoclimatology of the last 15 million years in marine and continental sequences. Palaeogeography, Palaeoclimatology, Palaeoecology, 16, 1-216.

Bukry, David, 1975. Coccolith and silicoflagellate stratigraphy, northwestern Pacific Ocean, Deep Sea Drilling Project Leg 32. In Larson, R. A., Moberly, R. M., Jr., et al., Init. Repts. DSDP, 32: Washington (U. S. Govt. Printing Office), pp. 677-718.

Christensen, N. I., Fountain, D. M., and Stewart, R. J., 1973. Oceanic crustal basement: A comparison of seismic properties of DSDP basalts and consolidated sediments. Mar. Geol., 15, 215.

Donnelly, T. W., 1975. Neogene explosive volcanic activity of the western Pacific: Sites 292 and 296. In Karig, D. E., Ingle, J. C., Jr., et al., Init. Repts. DSDP, 31: Washington (U. S. Govt. Printing Office), pp. 577-597.

Echols, D. J., and Schaeffer, K., 1966. Microforaminifera from Little Stone Creek (Upper Eocene). Micropaleont., 6 (7), 399-415.

Fischer, A. G., Heezen, B. C., et al., 1971. Init. Repts. $D S D P, 6$ : Washington (U. S. Govt. Printing Office).

Foreman, H. P., 1975. Radiolaria from the North Pacific, Deep Sea Drilling Project. In Larson, R., Moberly, R., et al., Init. Repts. DSDP, 32: Washington (U. S. Govt. Printing Office), pp. 579-676.

Karig, D. E., Ingle, J. C., Jr., et al., 1975. Init. Repts. DSDP, 31: Washington (U. S. Govt. Printing Office).

Karig, D. E., 1975. Basin genesis in the Philippine Sea. In Karig, D. E., Ingle, J. C., et al., Init. Repts. DSDP, 31: Washington (U. S. Govt. Printing Office), pp. 857-880.

Kennett, J. P., McBirney, A. R., and Thunnell, R. C., 1977. Episodes of Cenozoic volcanism in the Circum-Pacific Region. J. Volcanol. and Geochem. Res., 2, 145-163.

Kling, S. A., 1973. Radiolaria from the Eastern North Pacific, Deep Sea Drilling Project, Leg 18. In Kulm, L. D., von
Huene, R., et al., Init. Repts. DSDP, 18: Washington (U. S. Govt. Printing Office), pp. 617-672.

Kobayashi, K., and Isezaki, N., 1976. Magnetic anomalies in the Sea of Japan and the Shikoku Basin: possible tectonic implications. In The Geophysics of the Pacific Ocean Basin and Its Margin: Am. Geophys. Union Mon. 19, pp. 235257.

Kobayashi, K., and Nakata, M., 1977. Local magnetic anomaly profiles, Shikoku Basin, northwestern Pacific Ocean (Map): Contrib. Geodynamics Project Japan, 77-2.

Ling, H. Y., 1975. Radiolaria: Leg 31 of the Deep Sea Drilling Project. In Karig, D. E., Ingle, J. C., et al. 1975. Init. Repts. DSDP, 31: Washington (U. S. Govt. Printing Office).

Murauchi, S., and Asanuma, T., 1974. Seismic reflection profiles and sonobuoy refraction measurements during GDP-6 to 8 voyages. Mar. Sci., 6, 23-27. 1977. Seismic Reflection Profiles in the Western Pacific, 1965-1974. Tokyo (Univ. of Tokyo Press).

Ridley, W. I., Rhodes, J. M., Reid, A. M., Jakes, P., Shih, C., and Bass, M. N., 1974. Basalts from Leg 6 of the DeepSea Drilling Project. J. Petrol., 15, 140-159.

Riedel, W. R. and Sanfilippo, A., 1978. Stratigraphy and evolution of tropical Cenozoic radiolarians. Micropaleont., 24, 61-96.

Saito, Tsunemasa, 1977. Late Cenozoic planktonic foraminifera datum levels: the present state of knowledge towards accomplishing Pan-Pacific stratigraphic correlation. Proc. First Internat. Congress Pacific Neogene Stratigraphy, 61-80.

Tomoda, Y., Kobayashi, K., Segawa, J., Nomura, M., Kimura, K., and Saki, T., 1975. Linear magnetic anomalies in the Shikoku Basin, northeastern Philippine Sea. J. Geomagnet. and Geoelec., 28, 47-56.

Van Andel, Tj. H., Heath, G. R., and Moore, T. C., Jr., 1975. Cenozoic history and paleoceanography of the Central equatorial Pacific Ocean. Geol. Soc. Am. Mem., 143.

Watts, A. N., and Weissel, J. K., 1975. Tectonic history of the Shikoku marginal basin. Earth Planet. Sci. Lett., 239-250. 


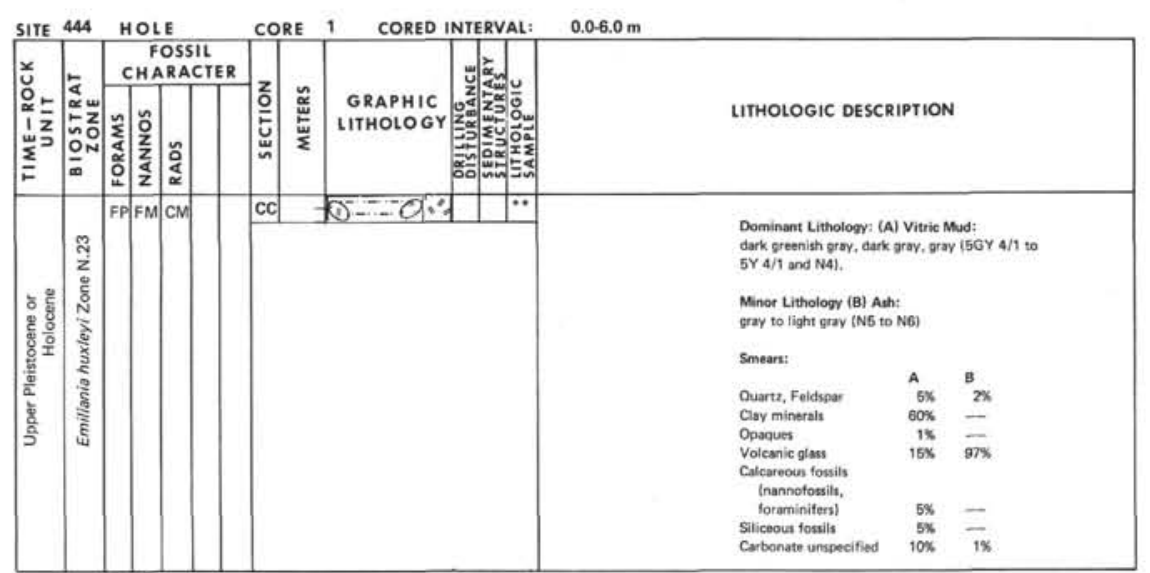

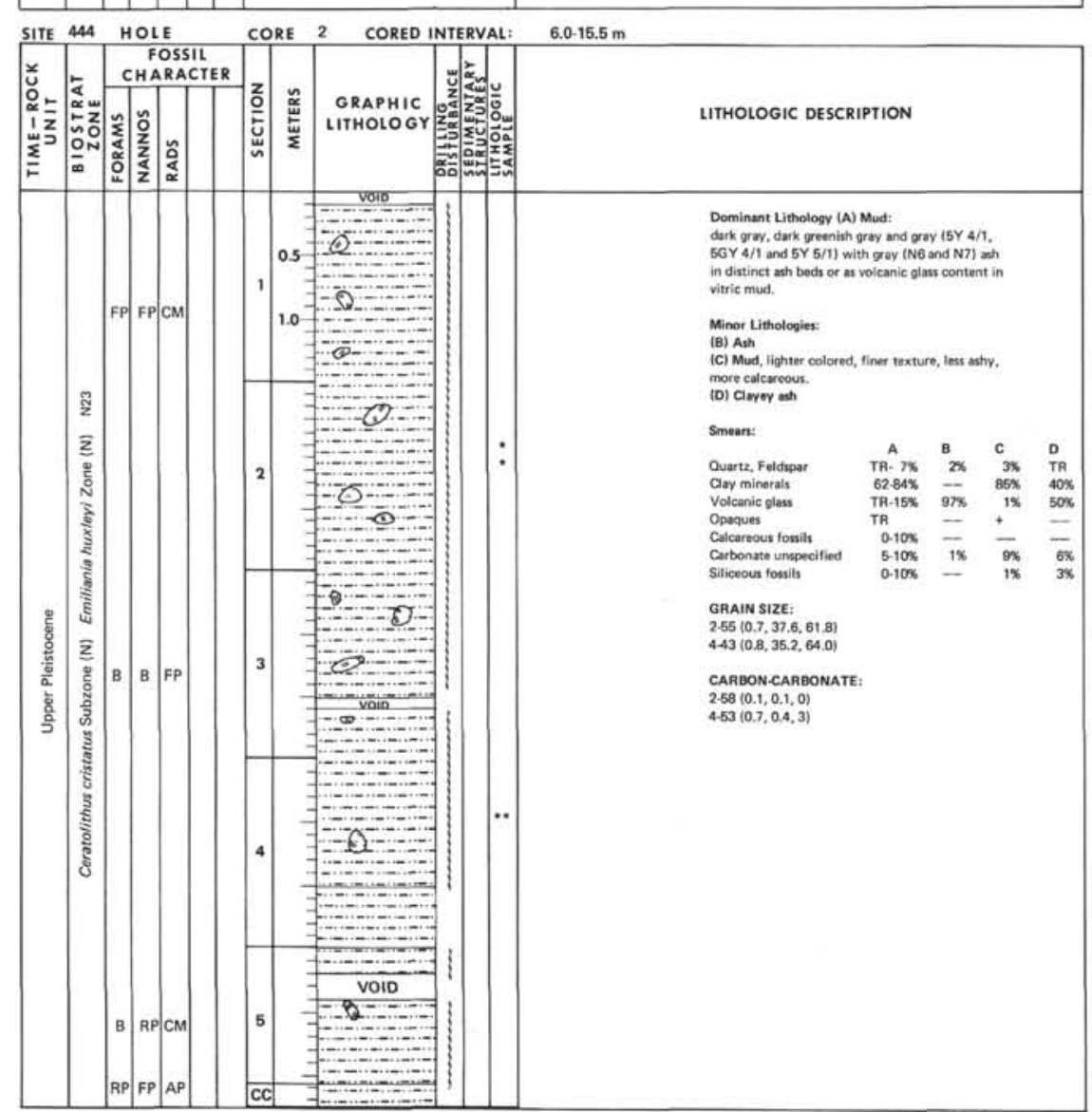

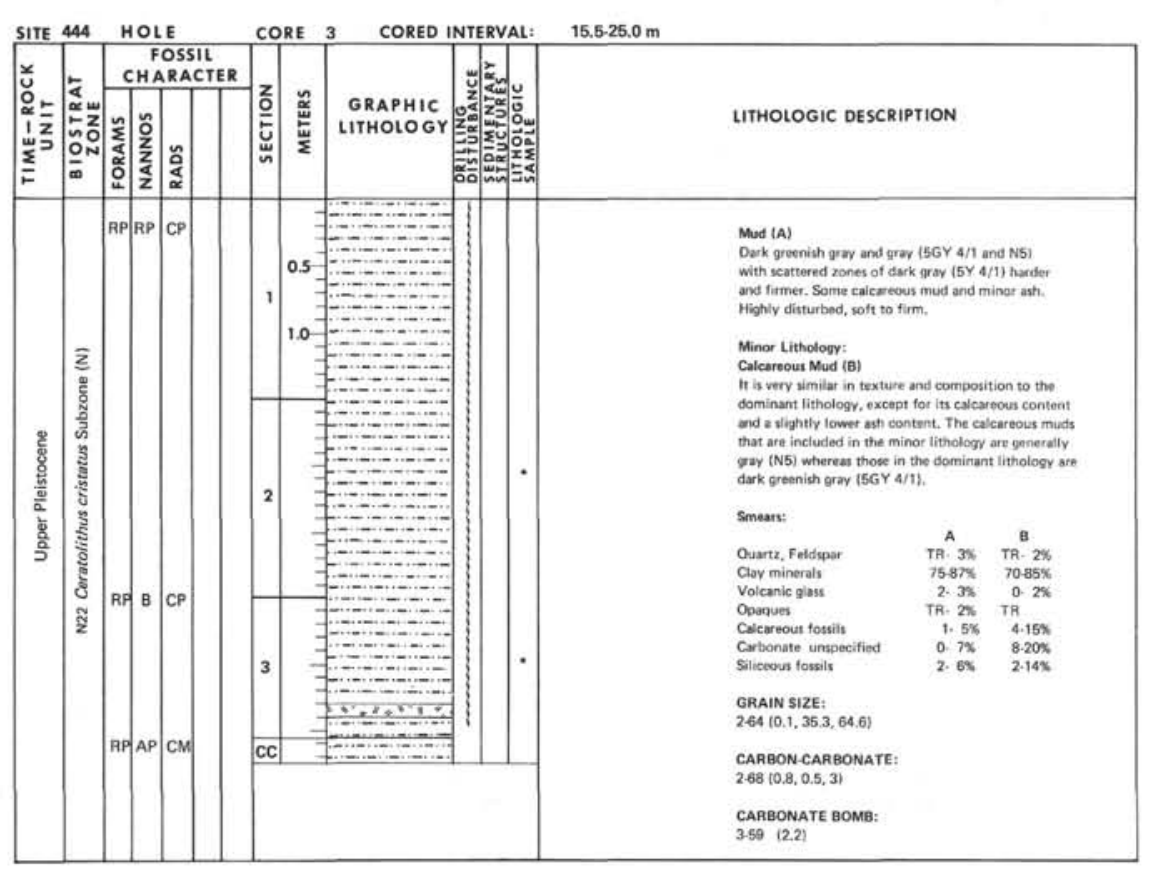




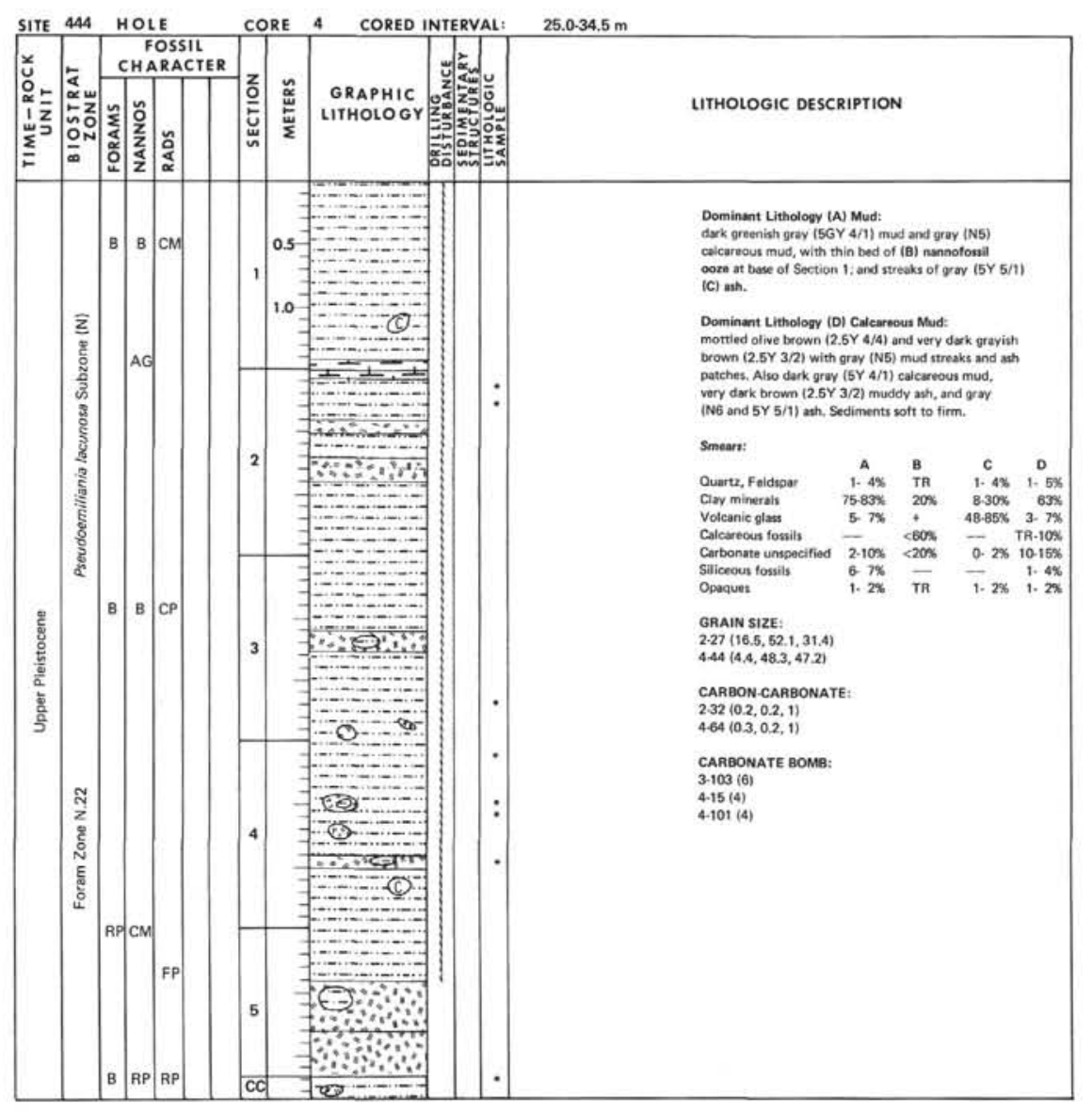

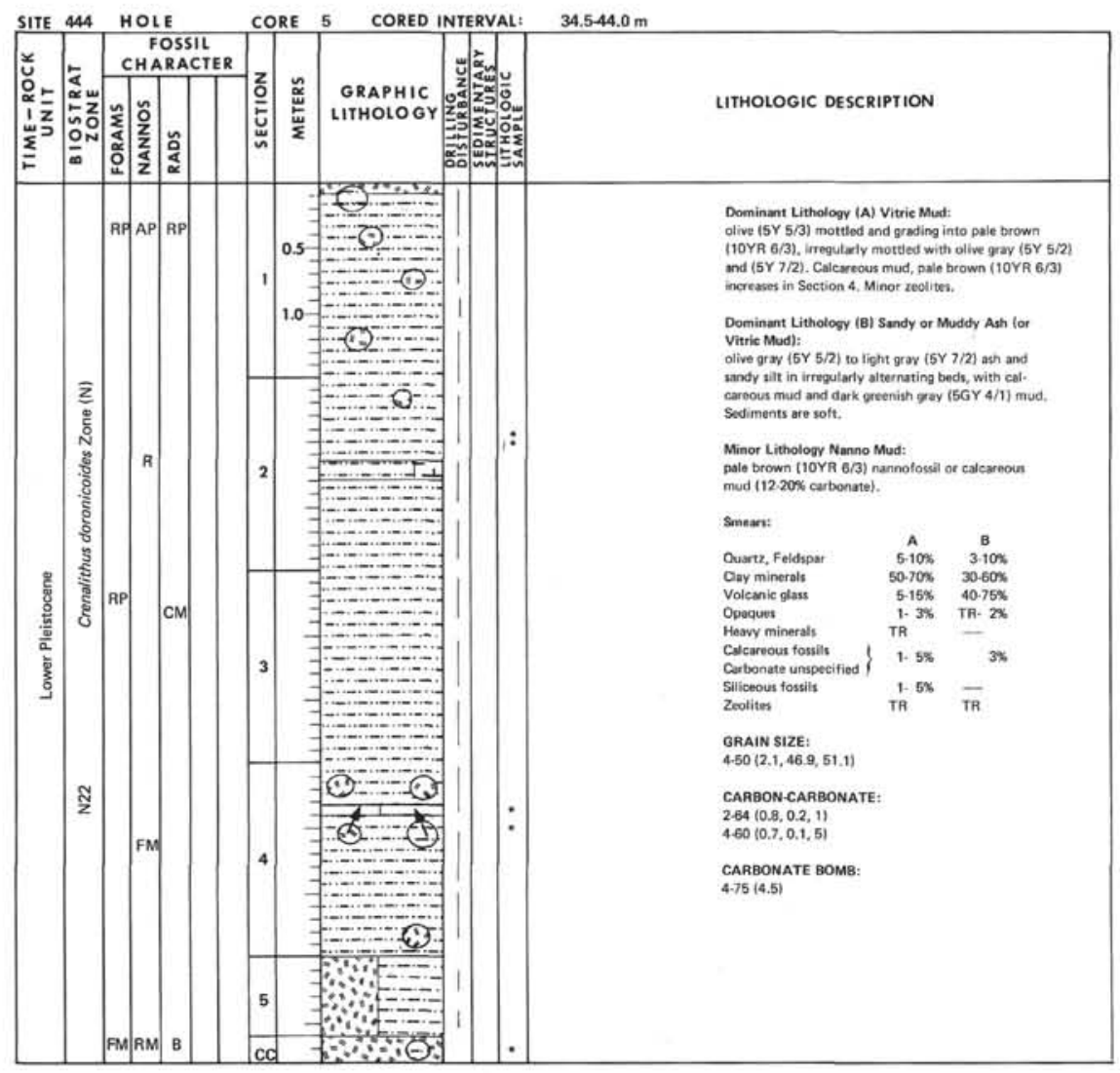




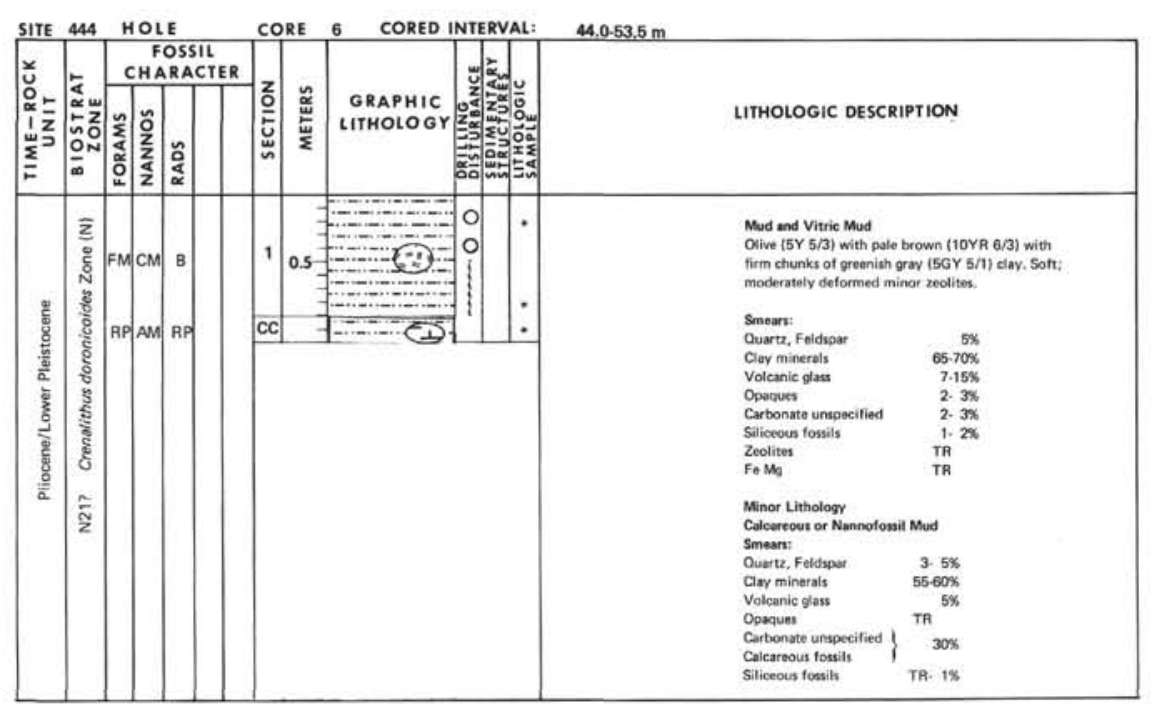

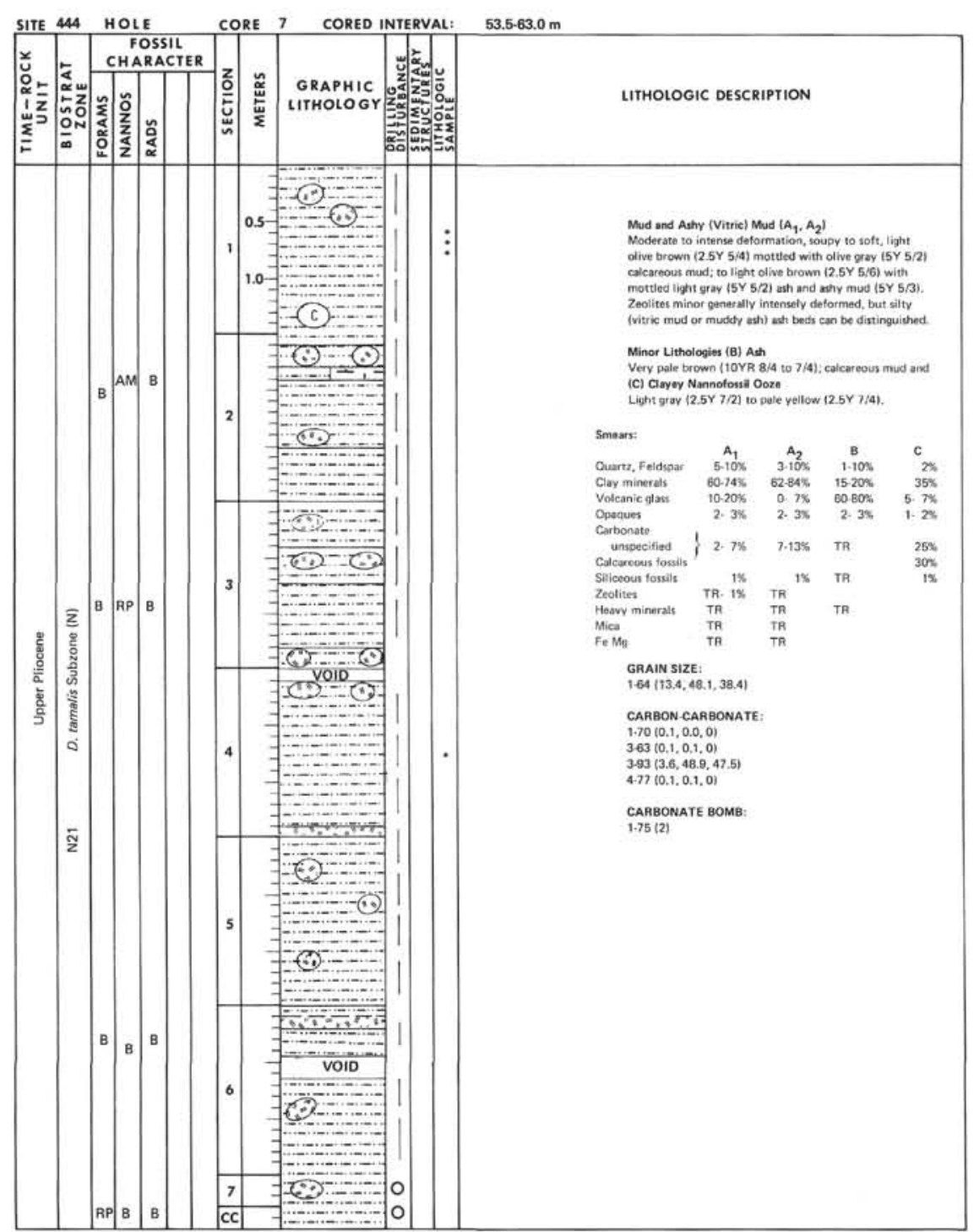




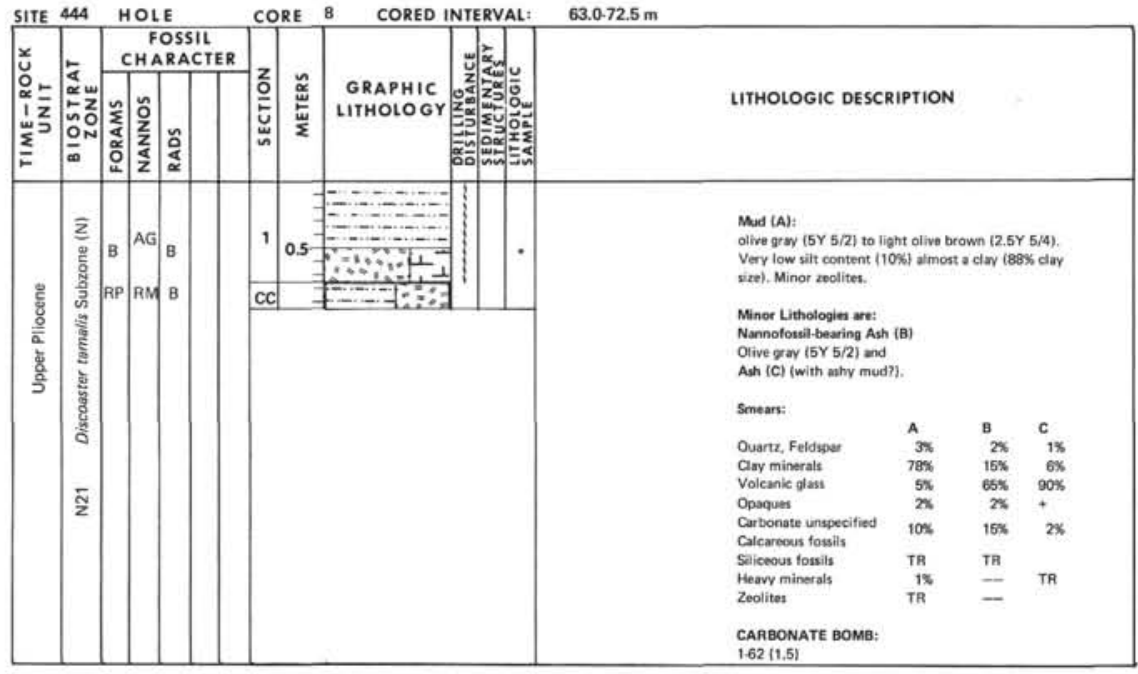

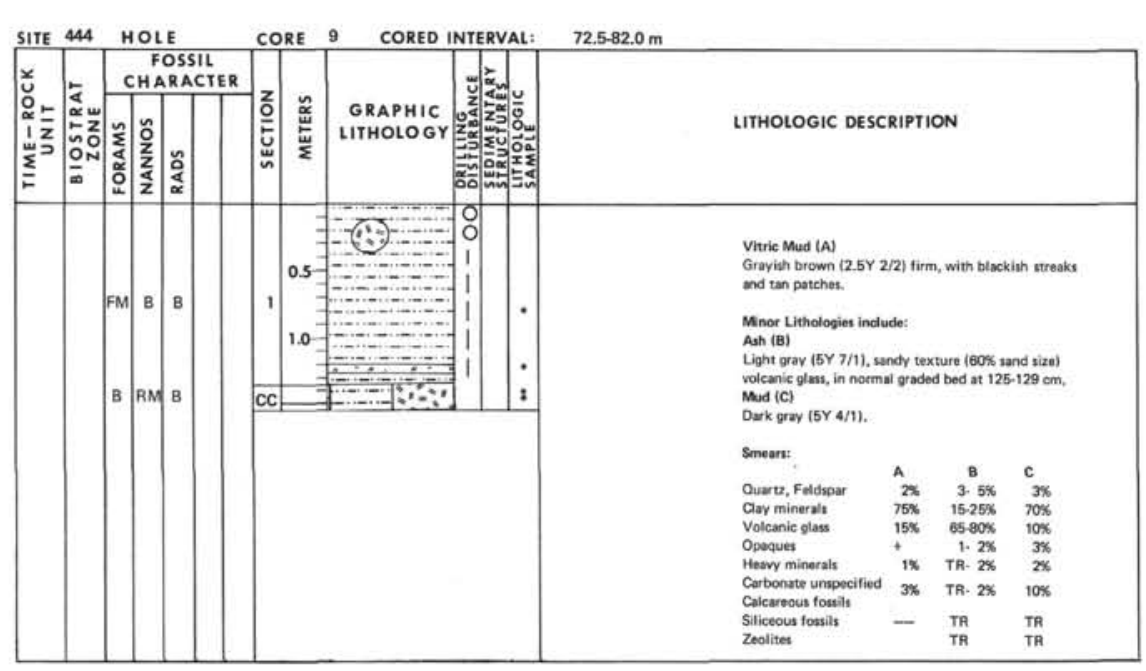

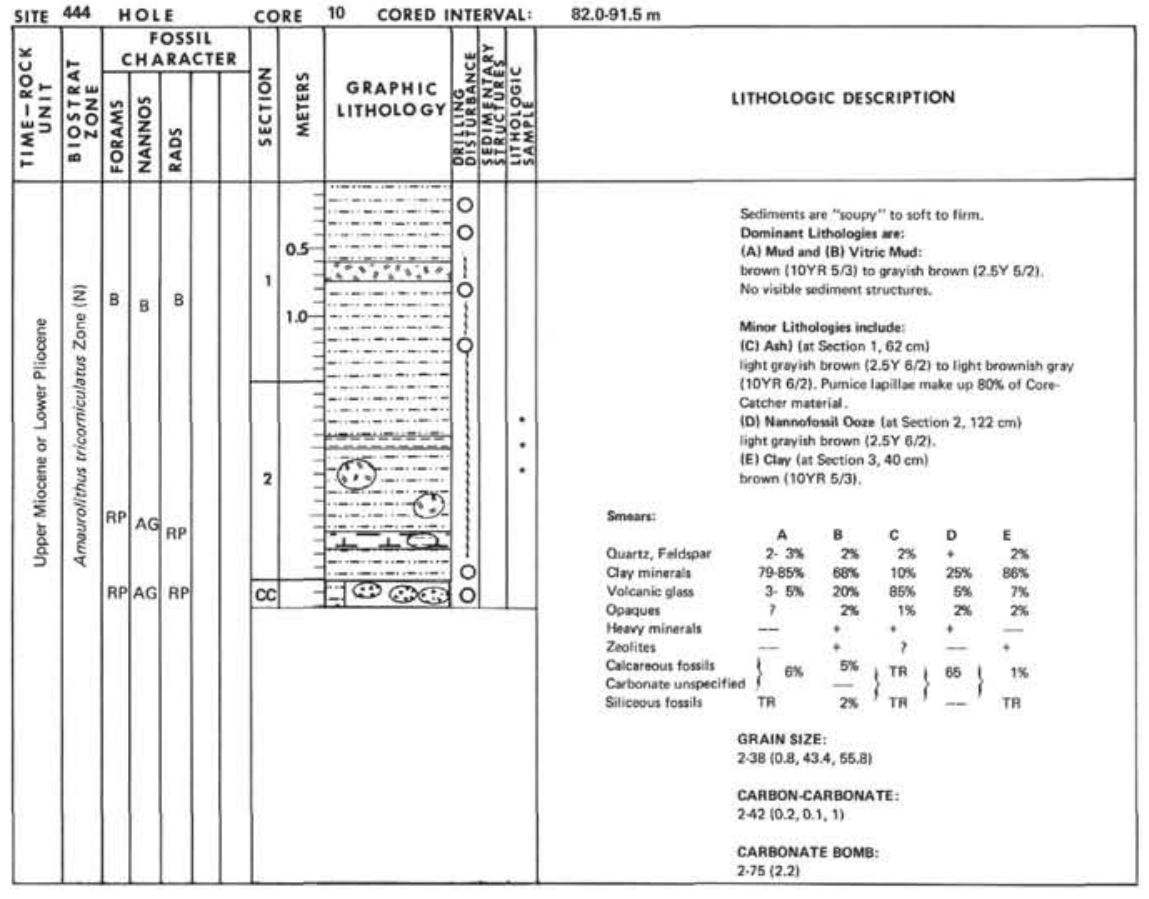




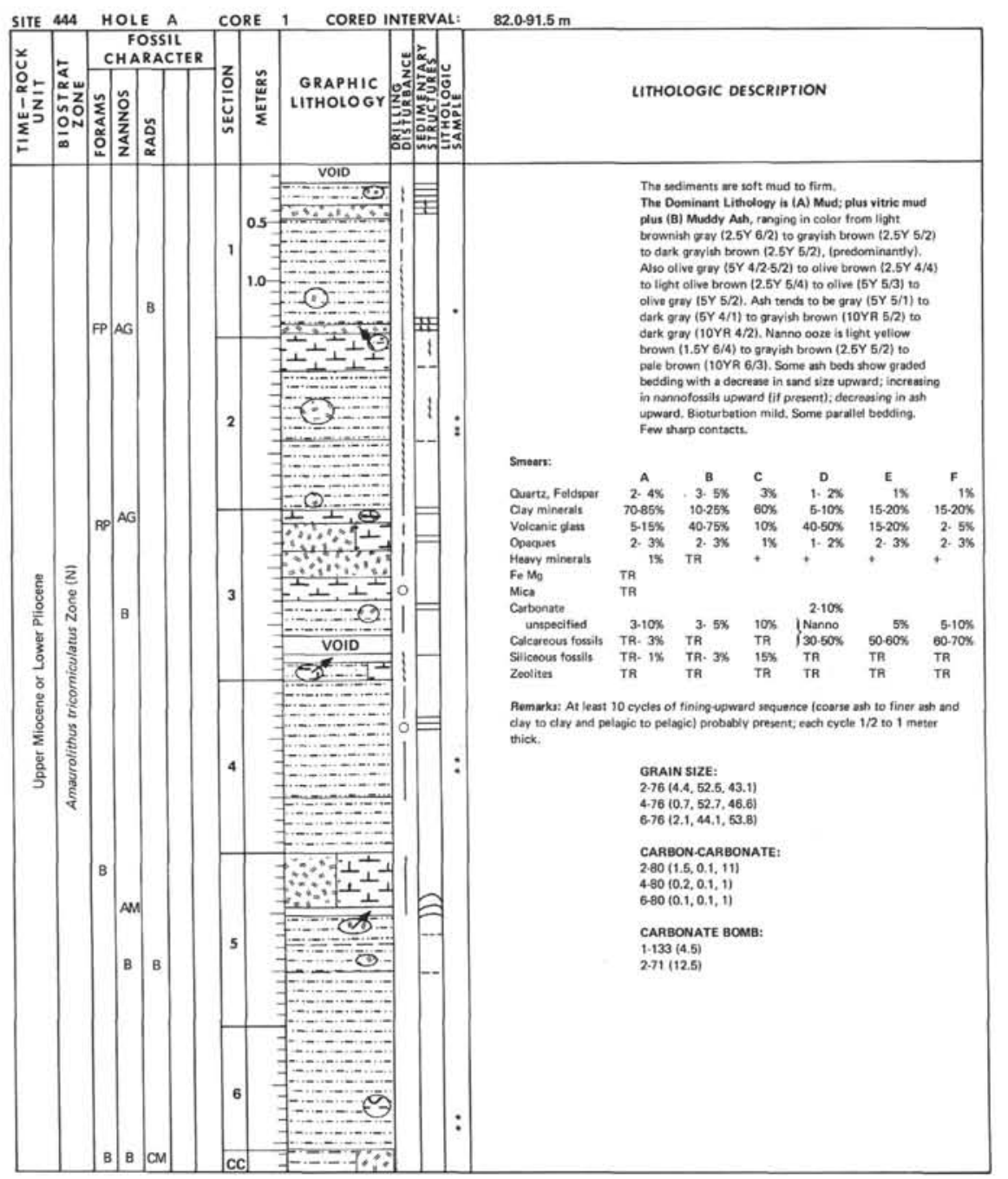

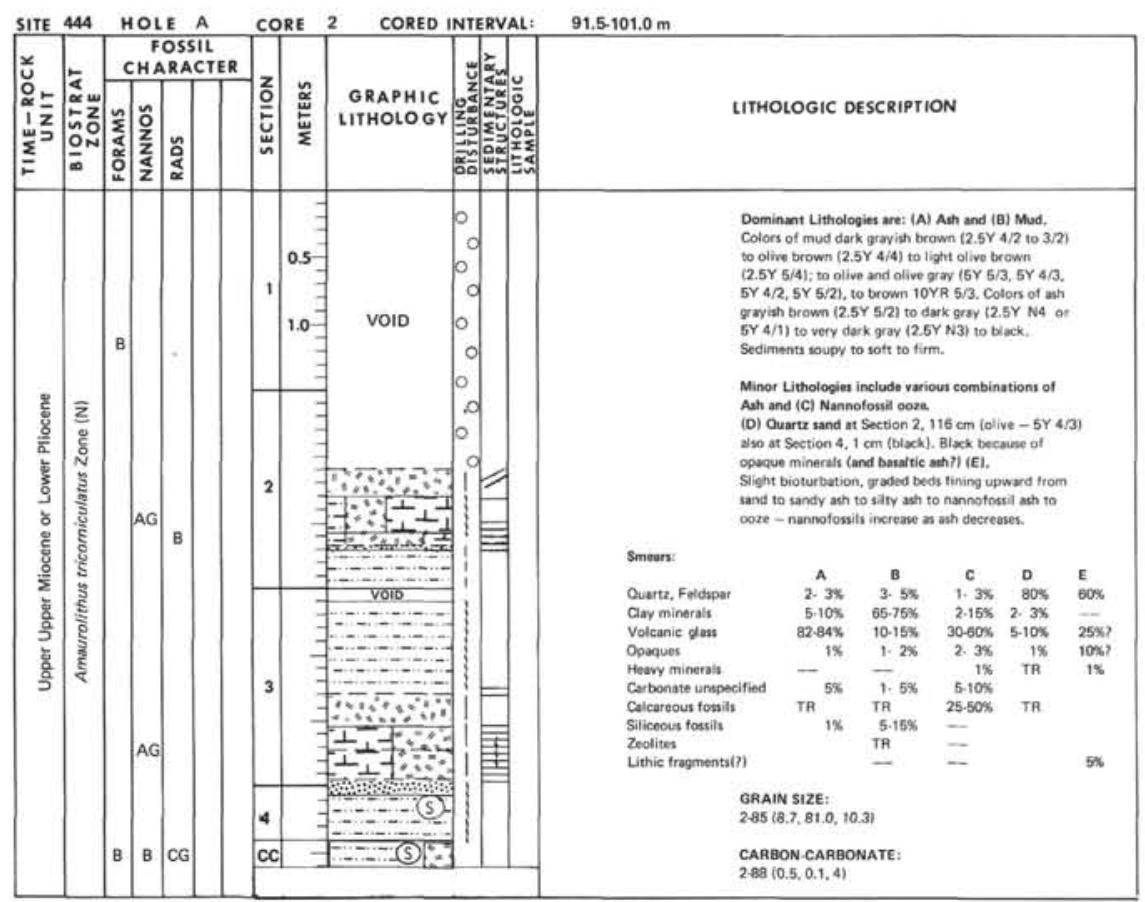




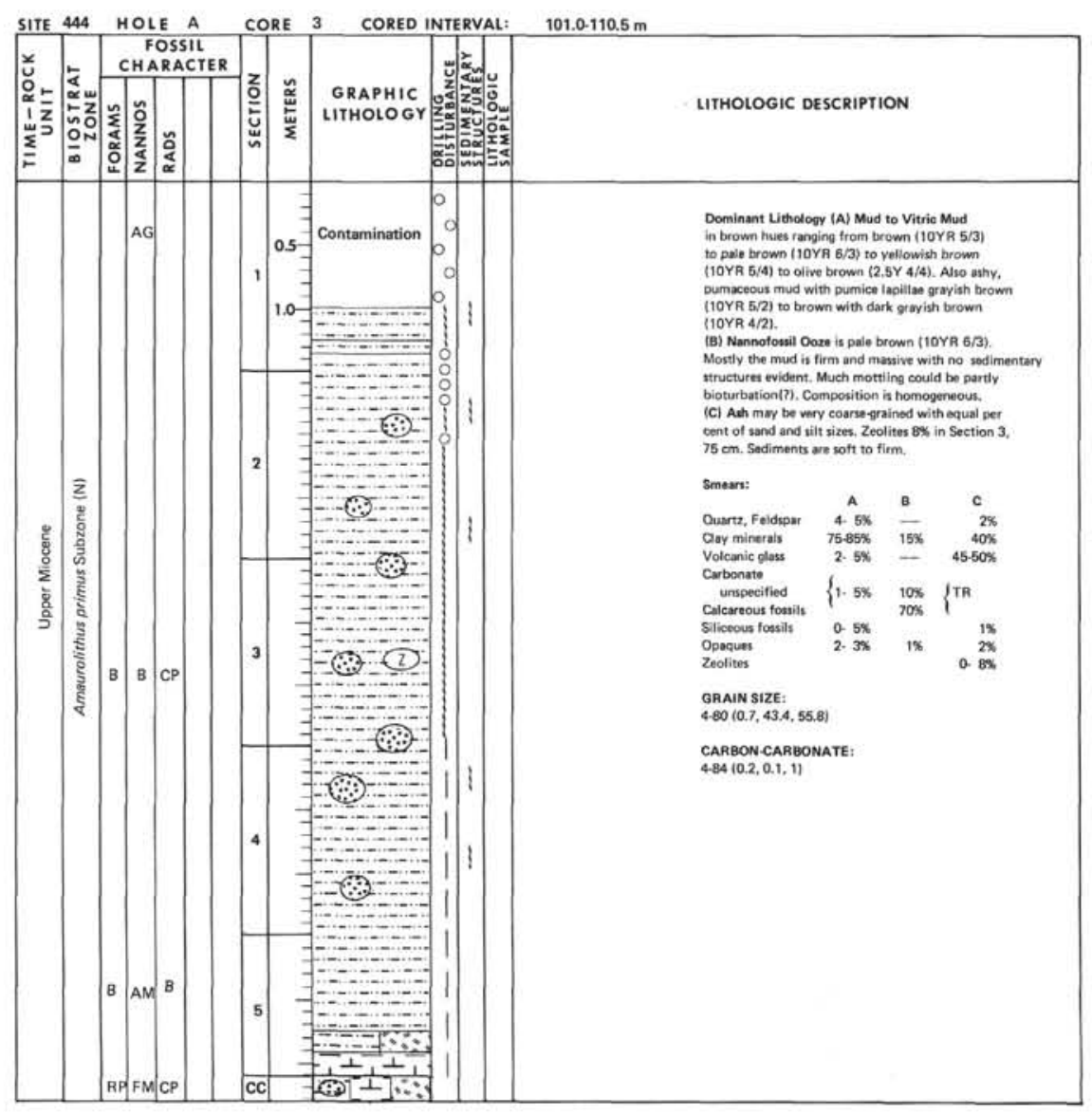

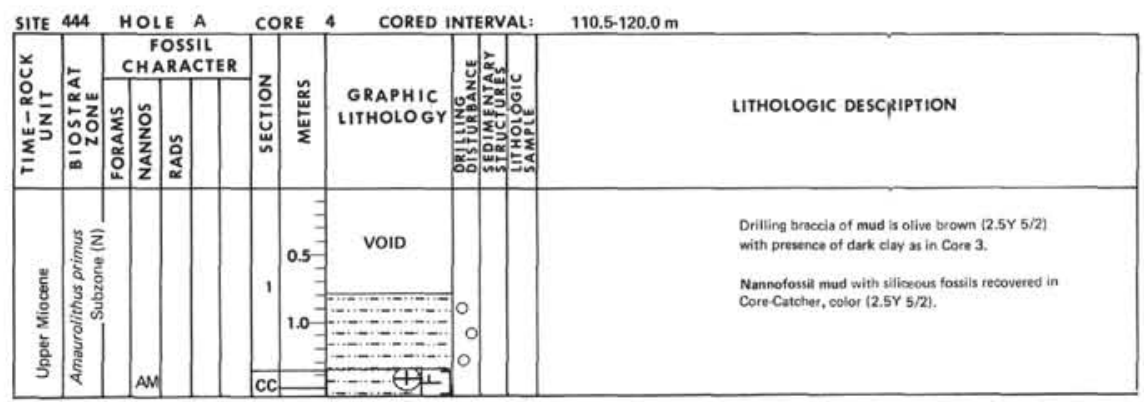

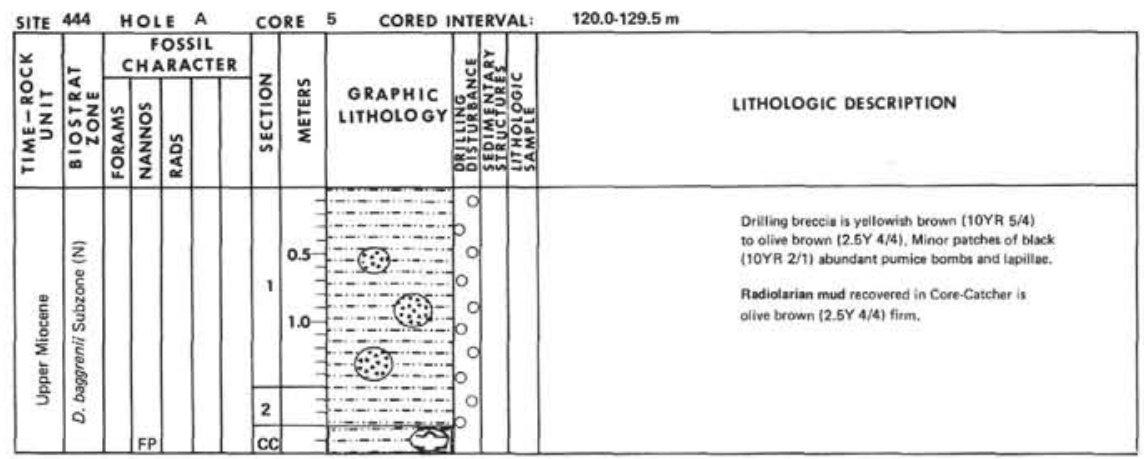




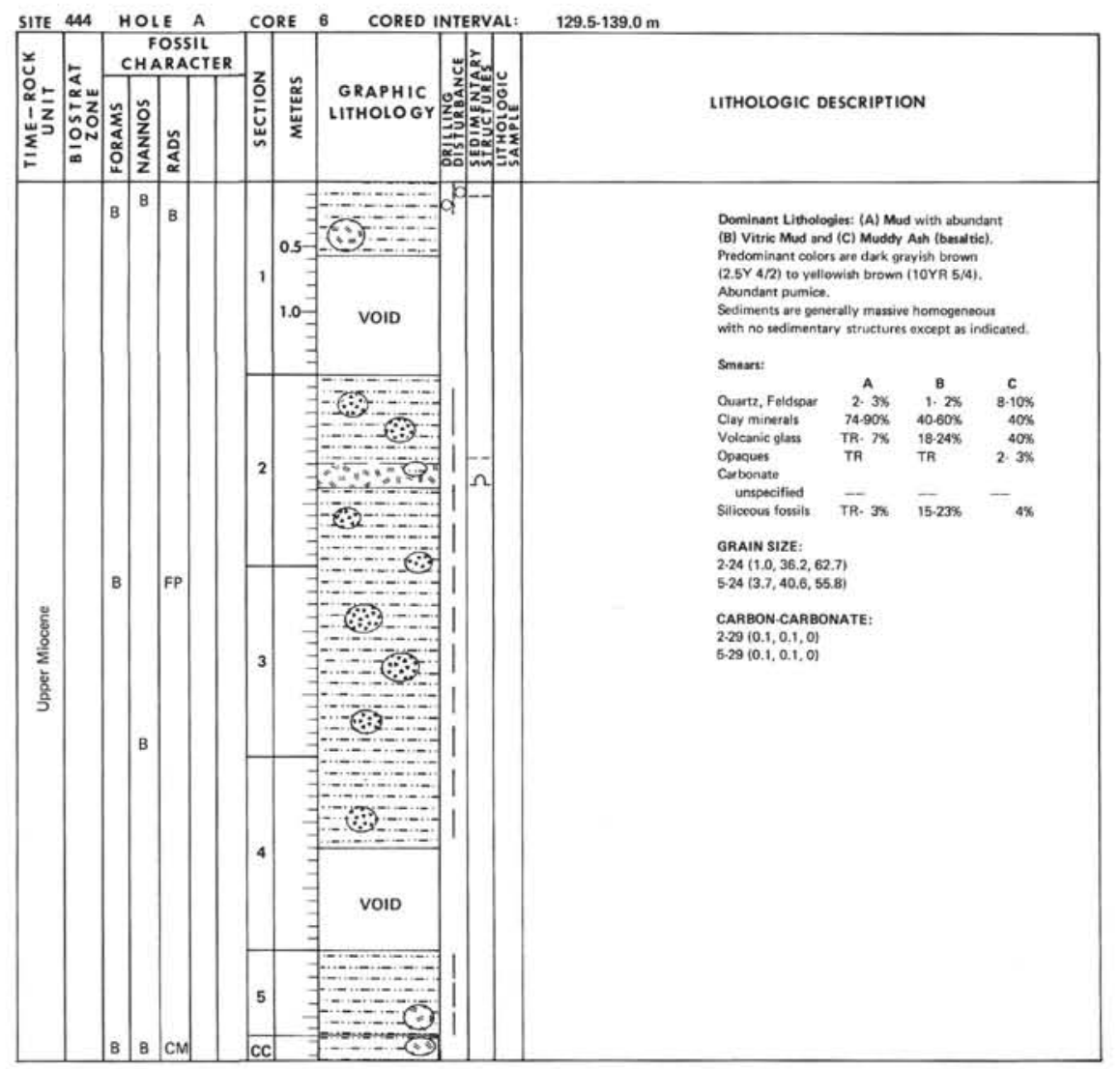

\begin{tabular}{|c|c|c|c|c|c|c|c|}
\hline \multirow{3}{*}{ 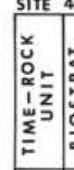 } & & \multirow{2}{*}{\multicolumn{2}{|c|}{$\begin{array}{c}\text { FOSSIL } \\
\text { CHARACTER }\end{array}$}} & \multirow{3}{*}{\multicolumn{2}{|c|}{ 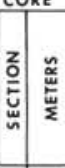 }} & RE & \multirow[b]{3}{*}{ LITHOLOGIC DESCRIPTION } \\
\hline & & & & & & & \\
\hline & & 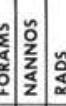 & 幽 & & & 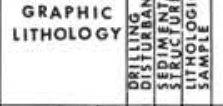 & \\
\hline \multirow[t]{2}{*}{ 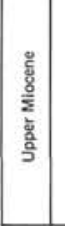 } & & \multirow[t]{2}{*}{ RMFP } & & \multirow{2}{*}{\multicolumn{2}{|c|}{\begin{tabular}{|l|l} 
& 0.5 \\
1.0 \\
$c C$
\end{tabular}}} & \begin{tabular}{r|r}
1 \\
\hdashline
\end{tabular} \mid & \multirow[t]{2}{*}{ 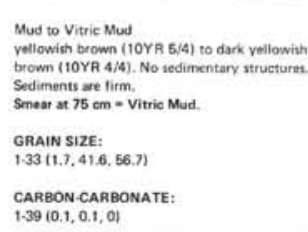 } \\
\hline & & & & & & & \\
\hline
\end{tabular}

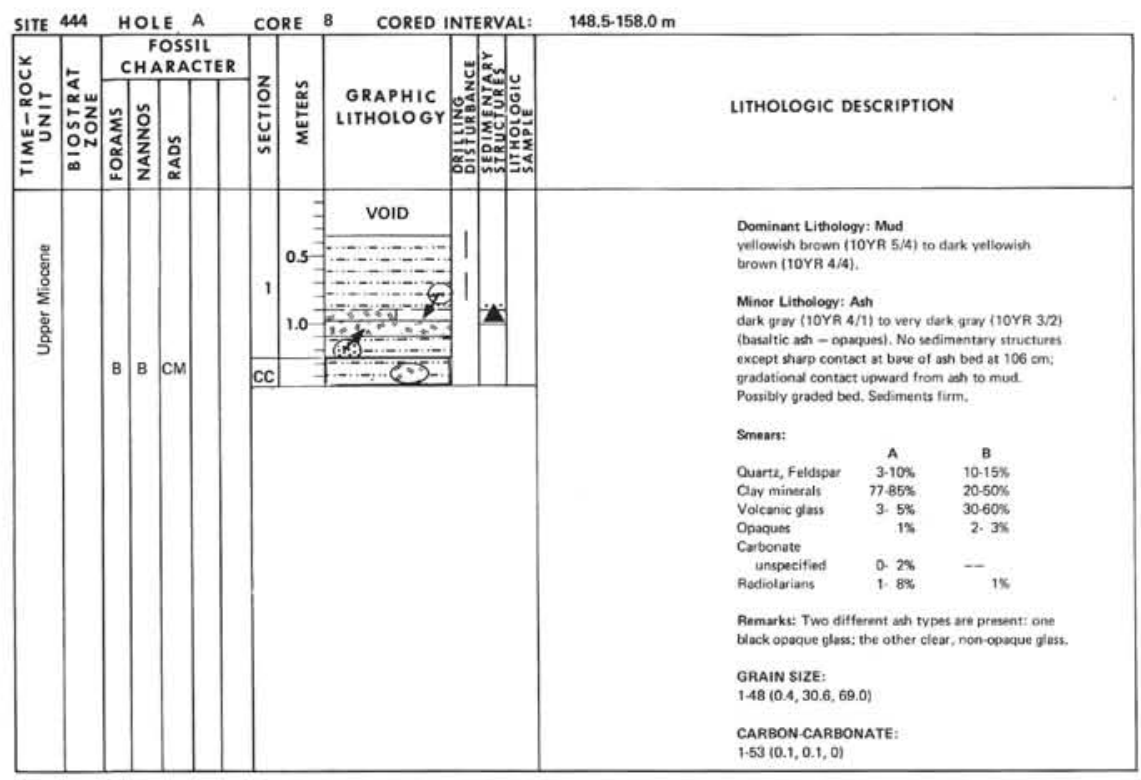




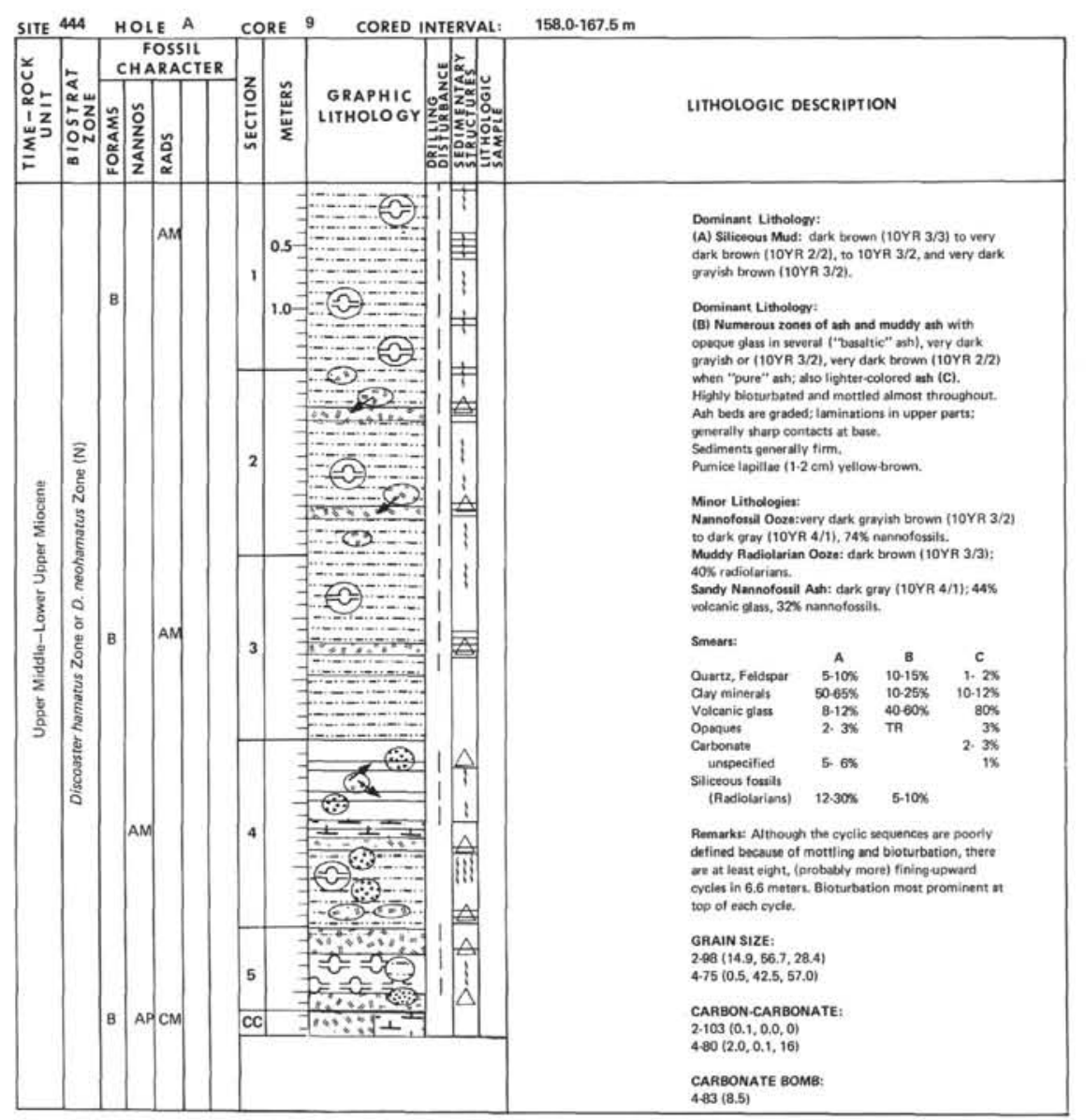

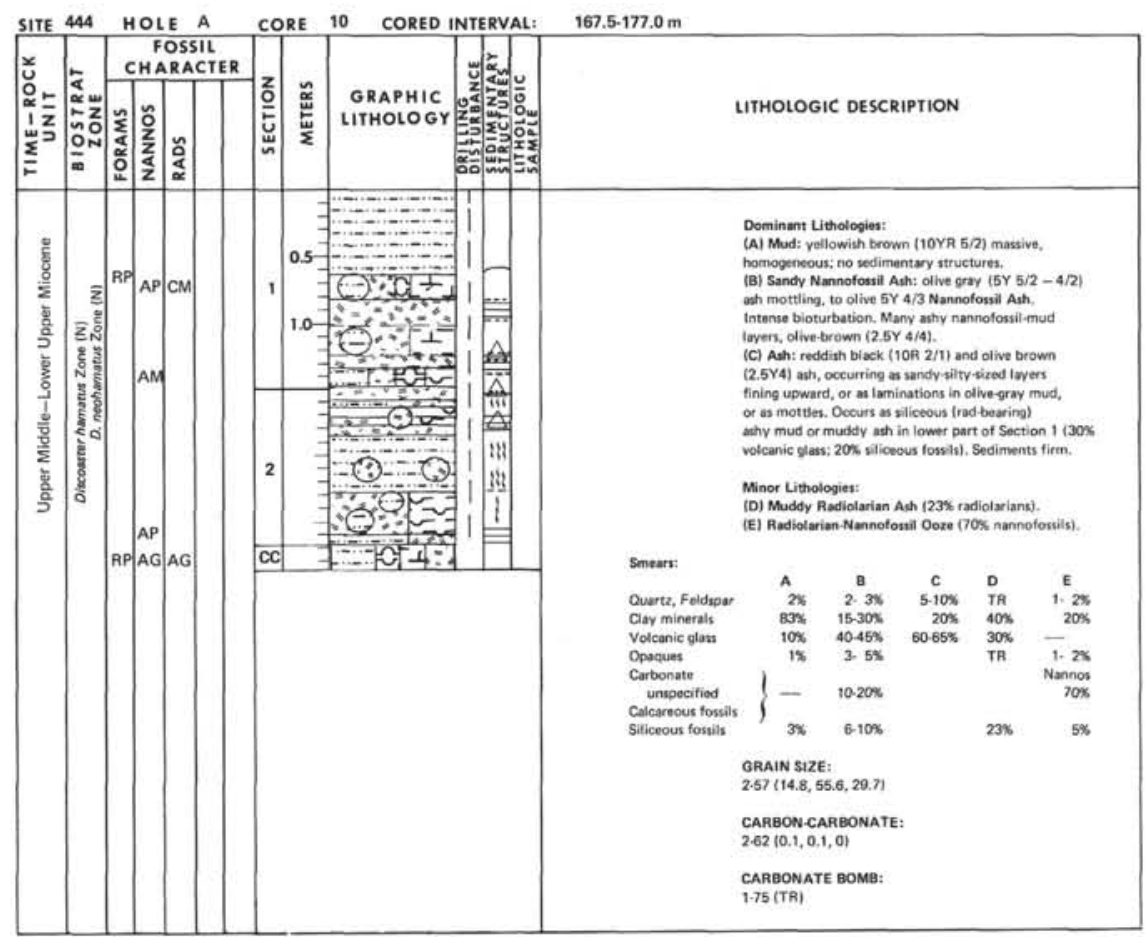




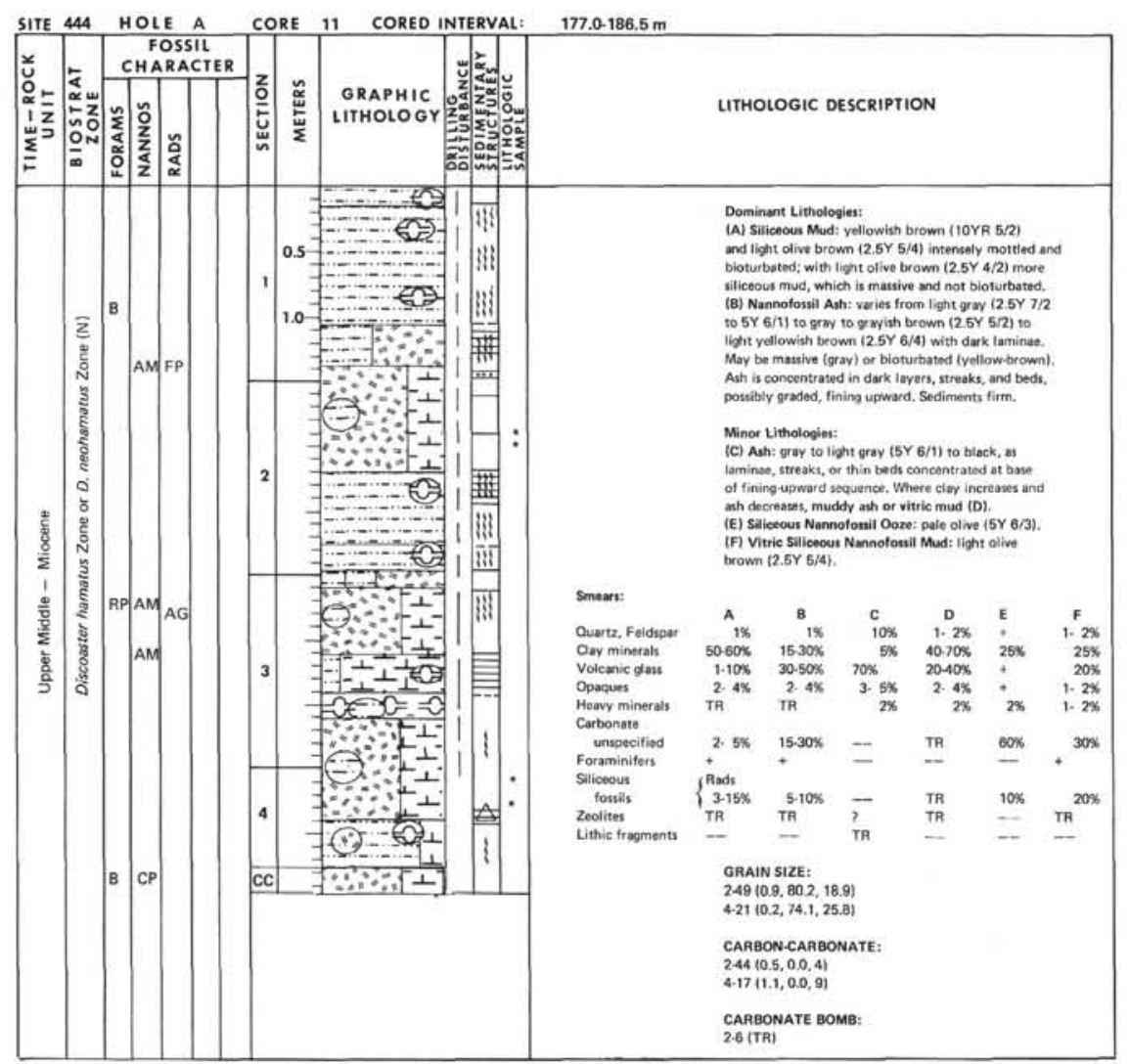

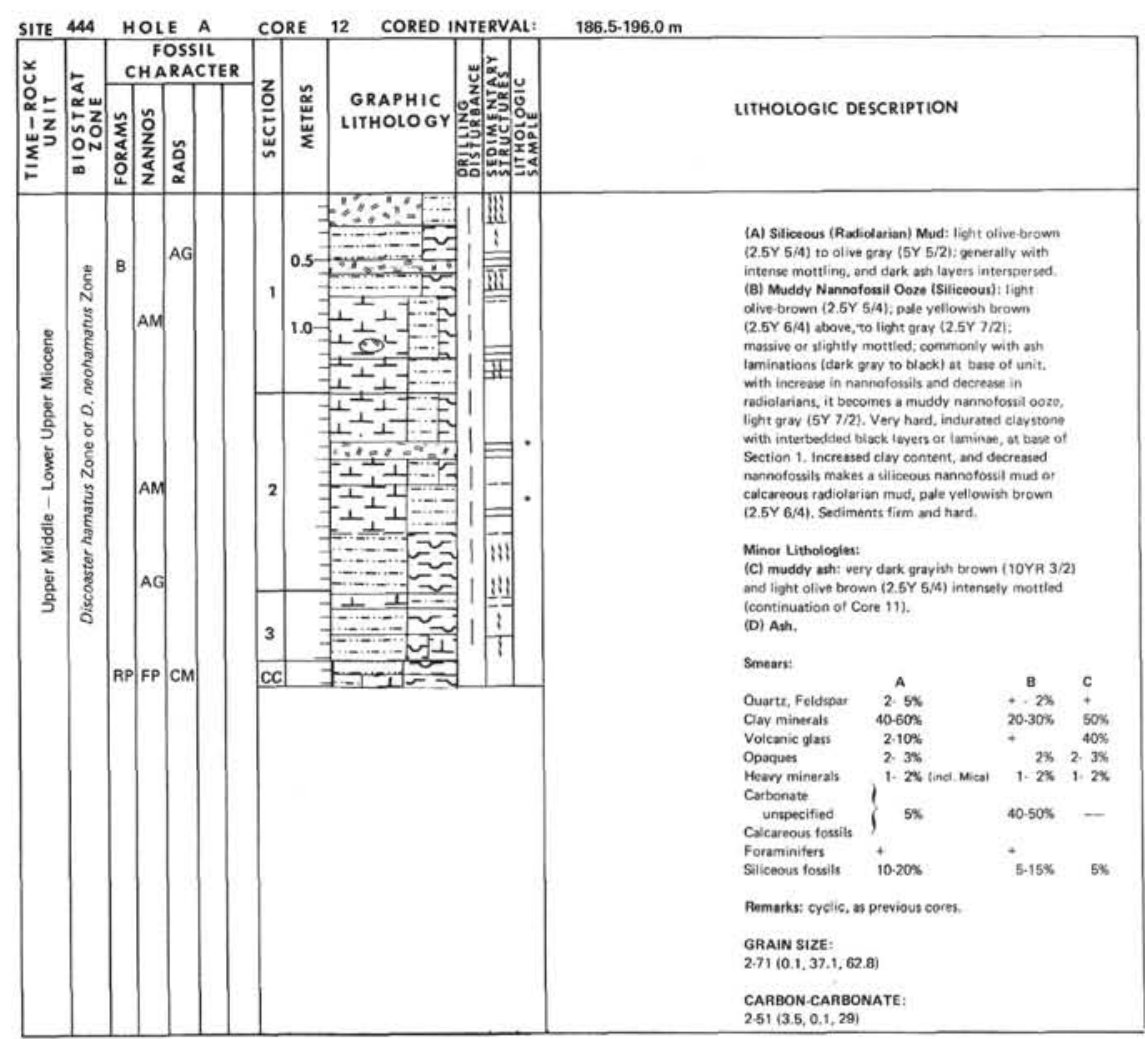




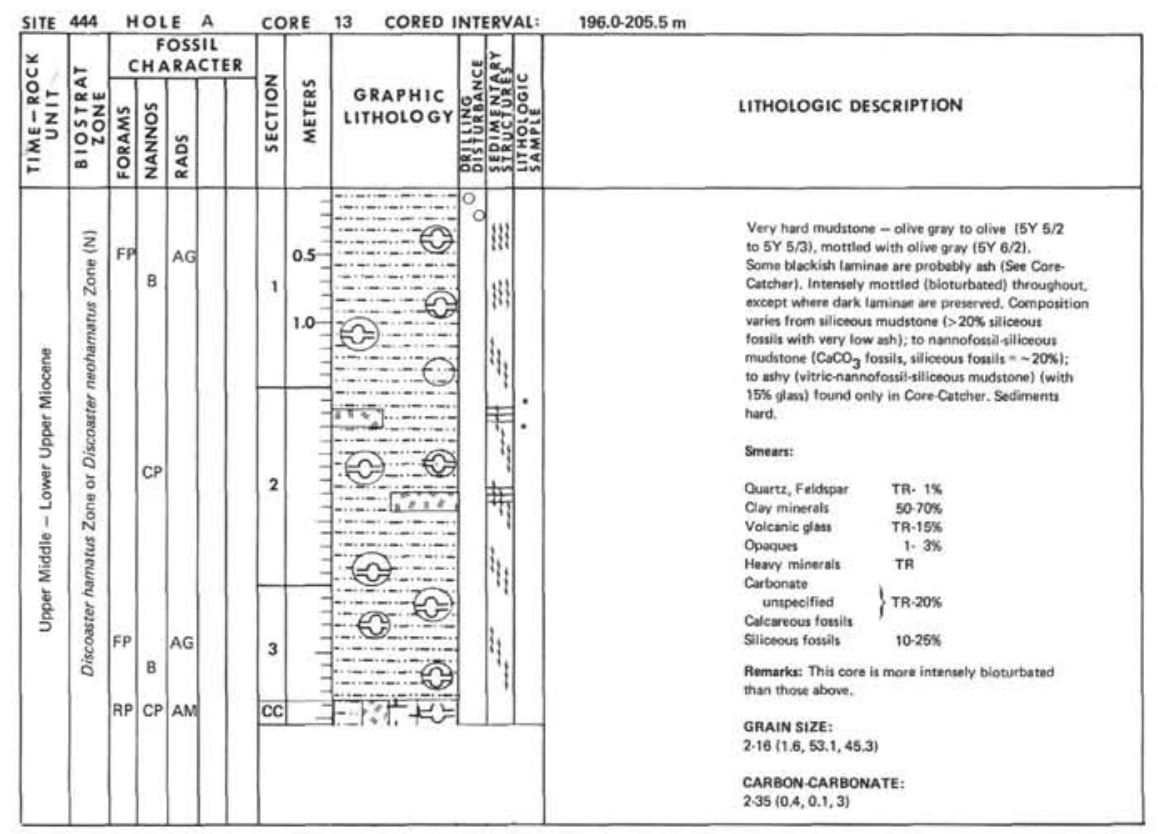

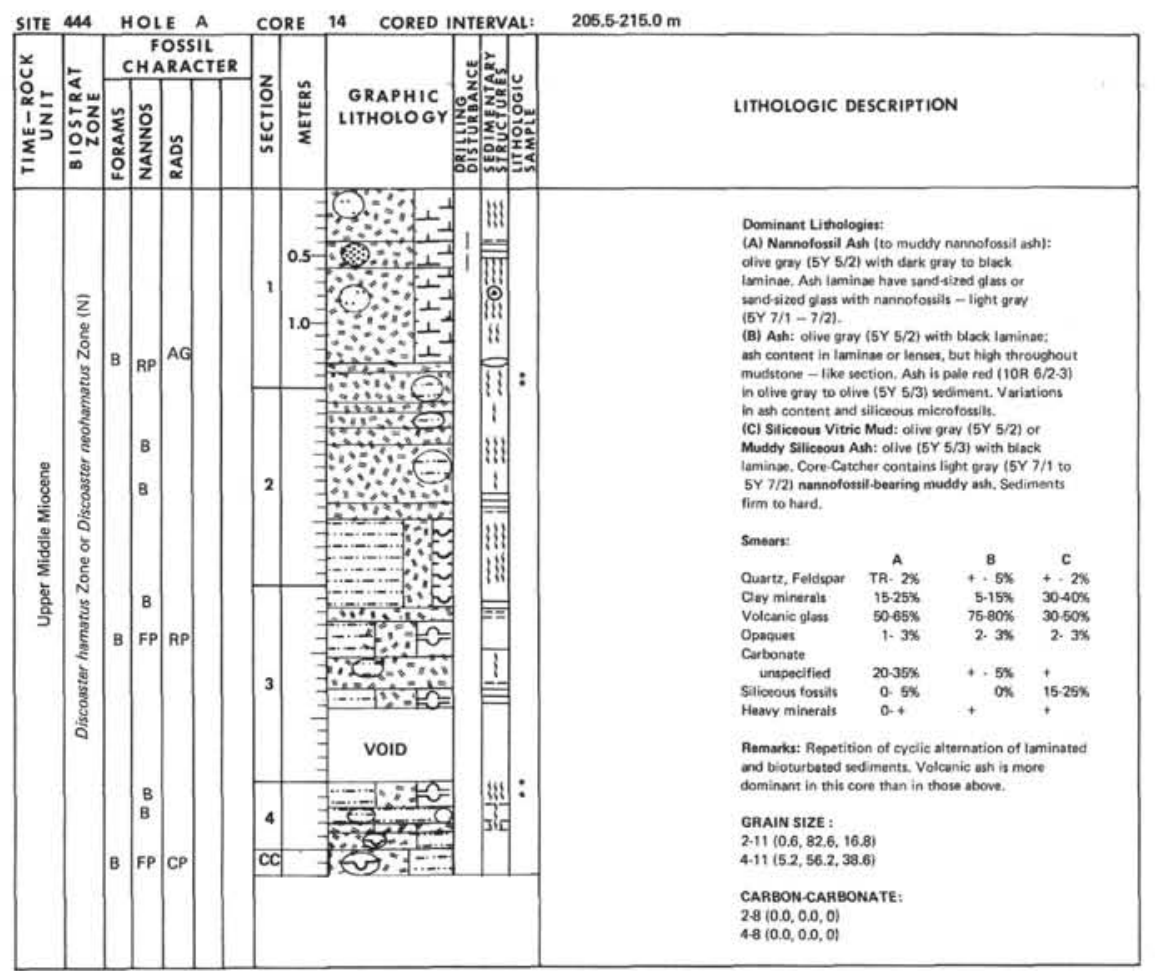




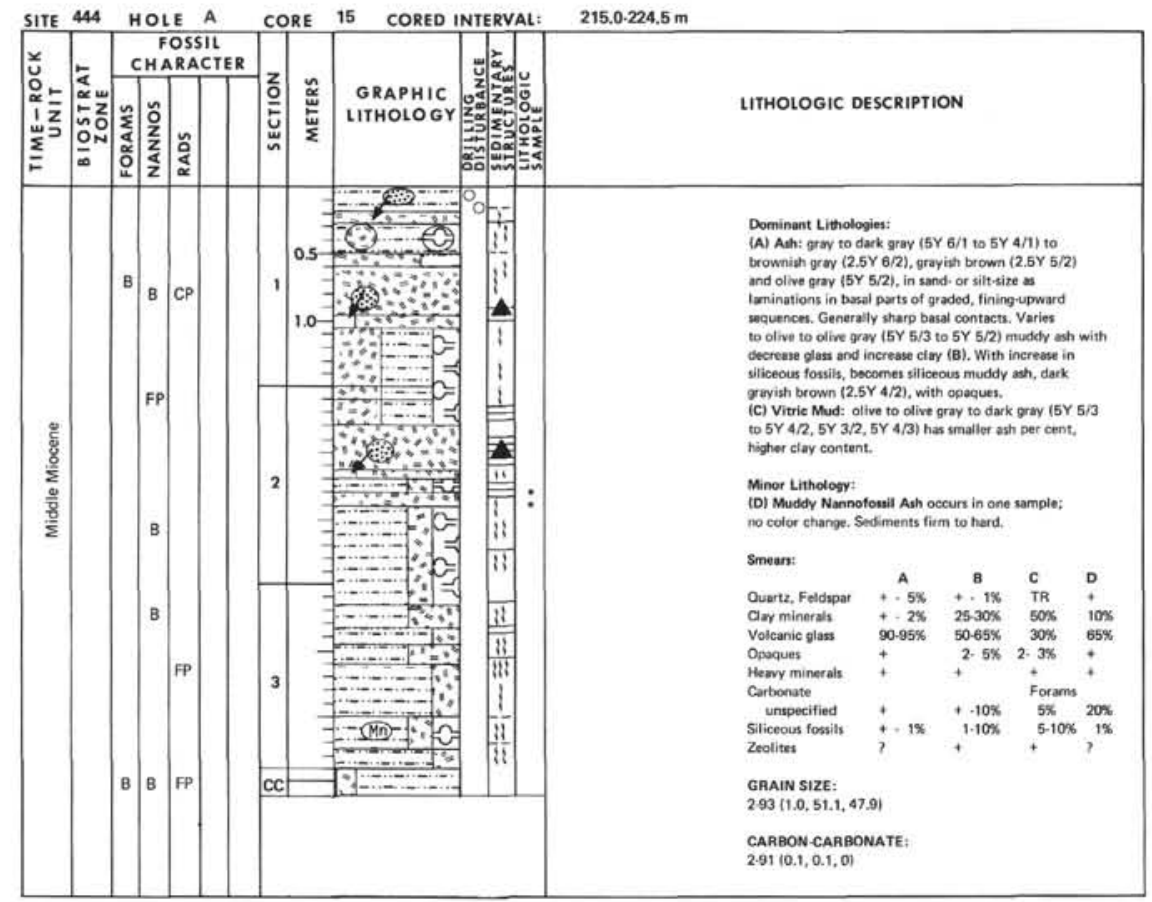

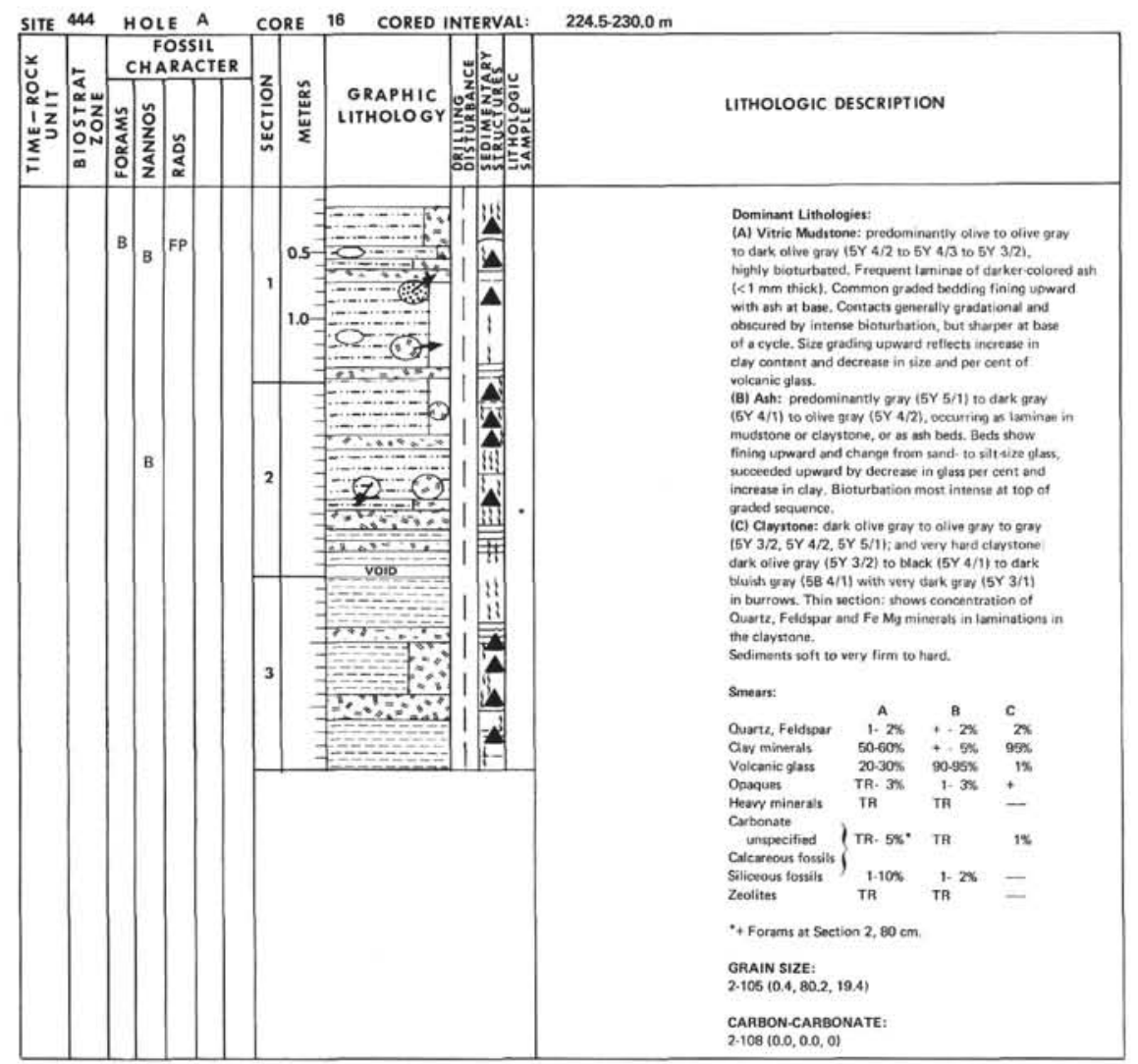




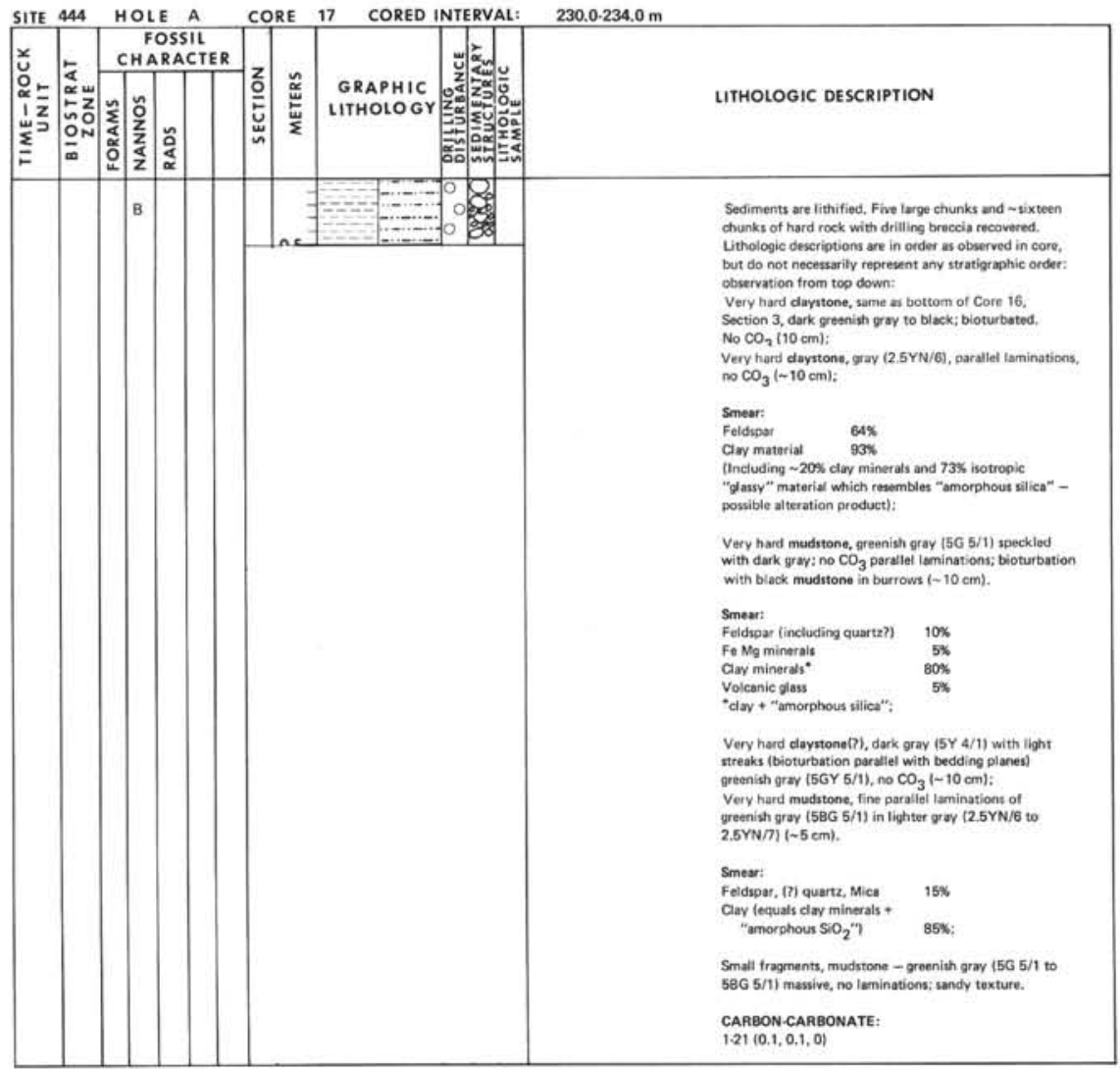

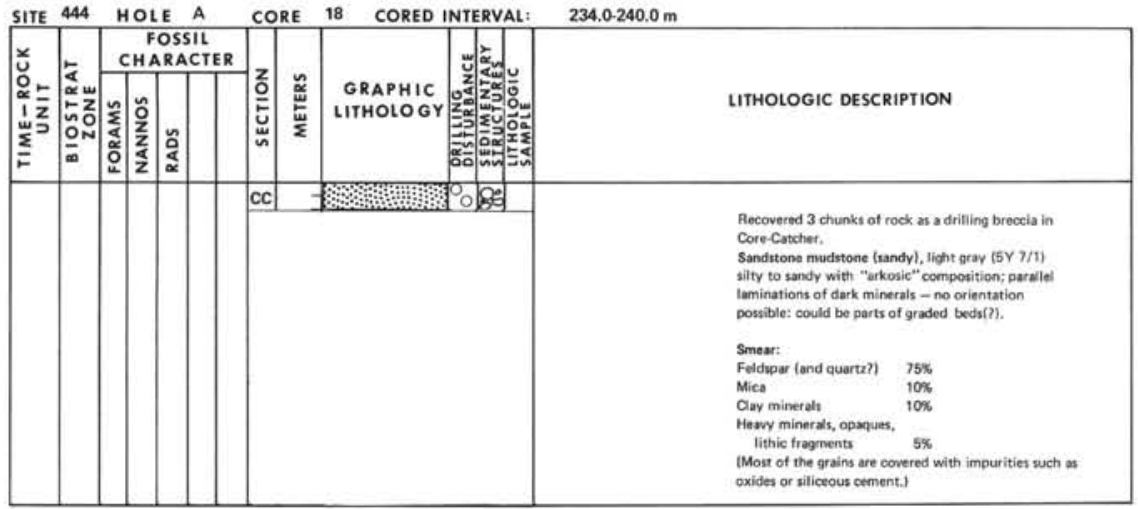

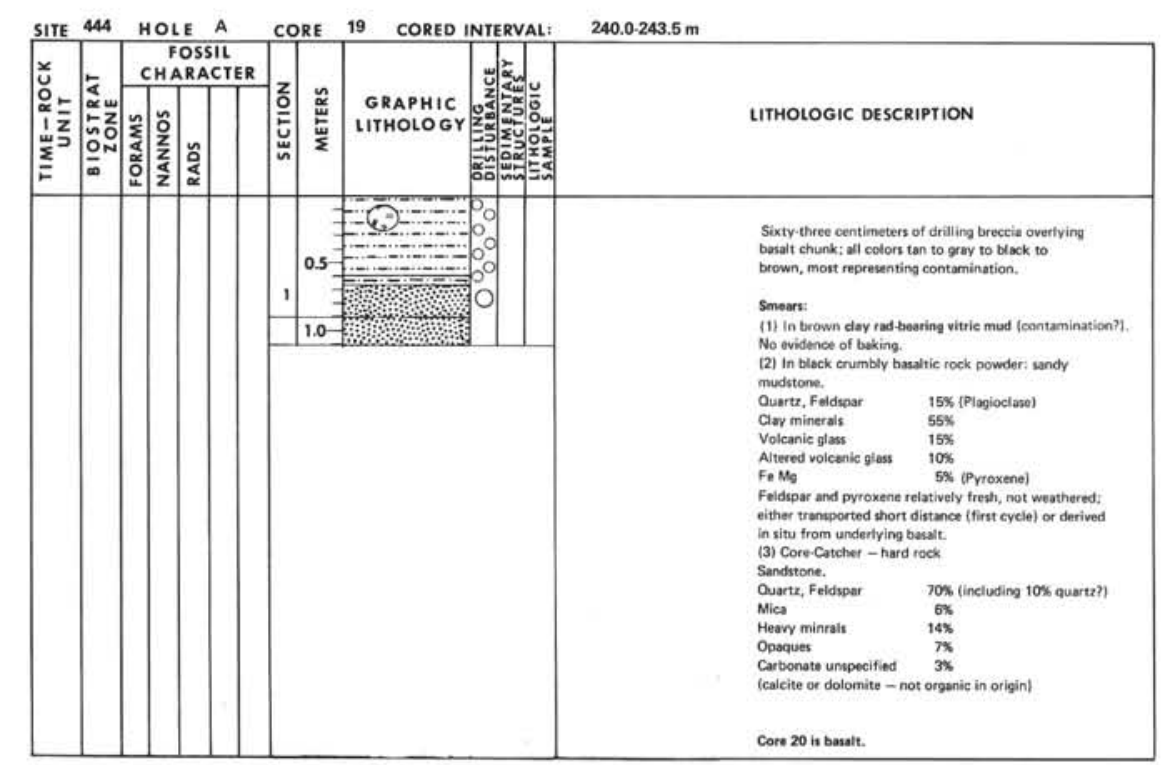



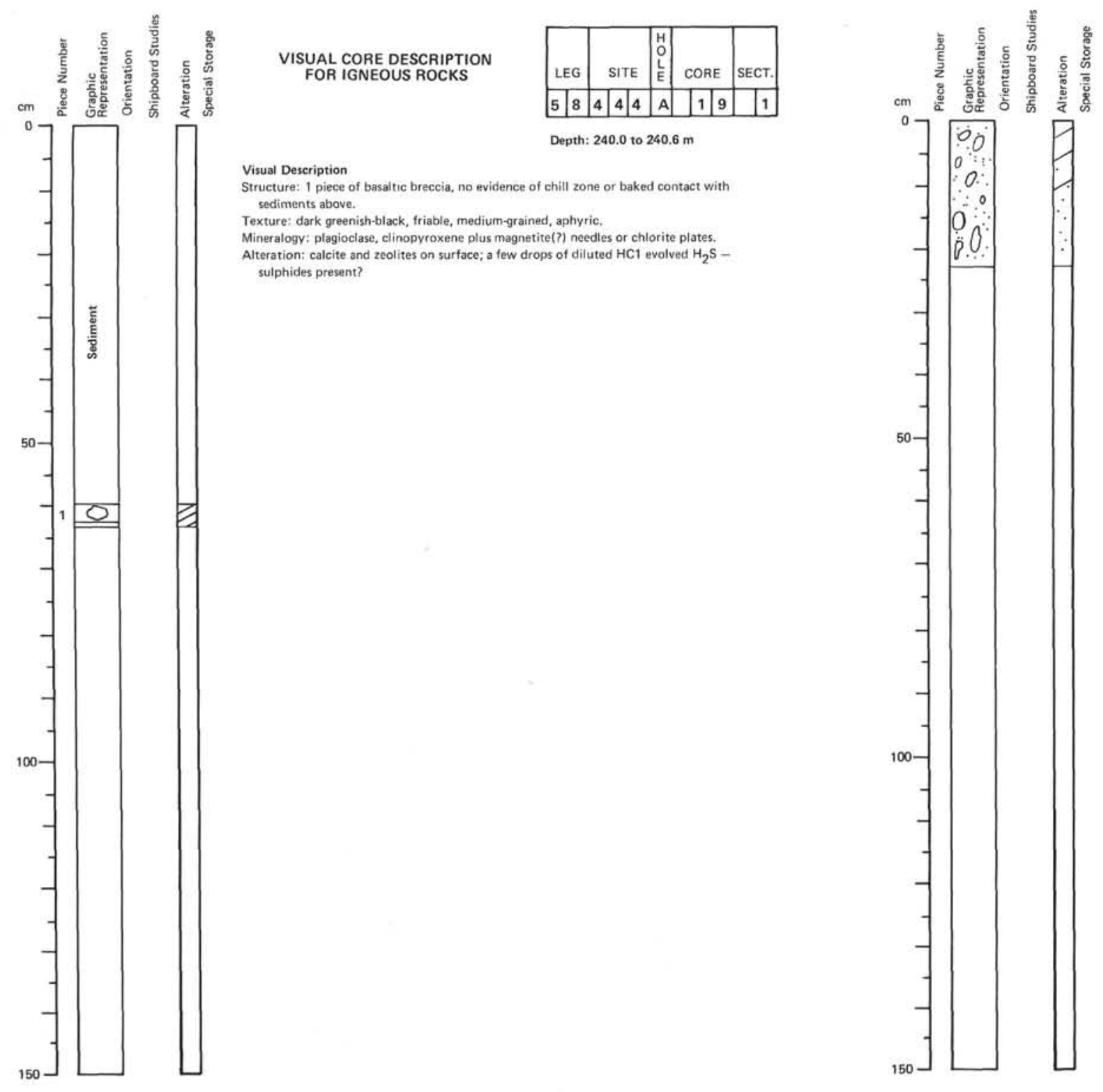

VISUAL CORE DESCRIPTION FOR IGNEOUS ROCKS

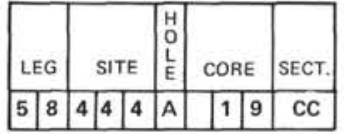

Depth: 240.6 to $240.9 \mathrm{~m}$

Visual Description

ofe of pebies and basaltic sand

exture: medium-grained, aphyric.

eedles or chlorite plates(?

$60.63 \mathrm{~cm}, 10.23 \mathrm{~cm}$ light aray pebbles predominate, solid Caleite and zeolines priosent some pebbles.

Thin Section Description

mgnetite, 5\%, Vesicles: $2 \%$ empty.

Texture: intersertal, subophitic 

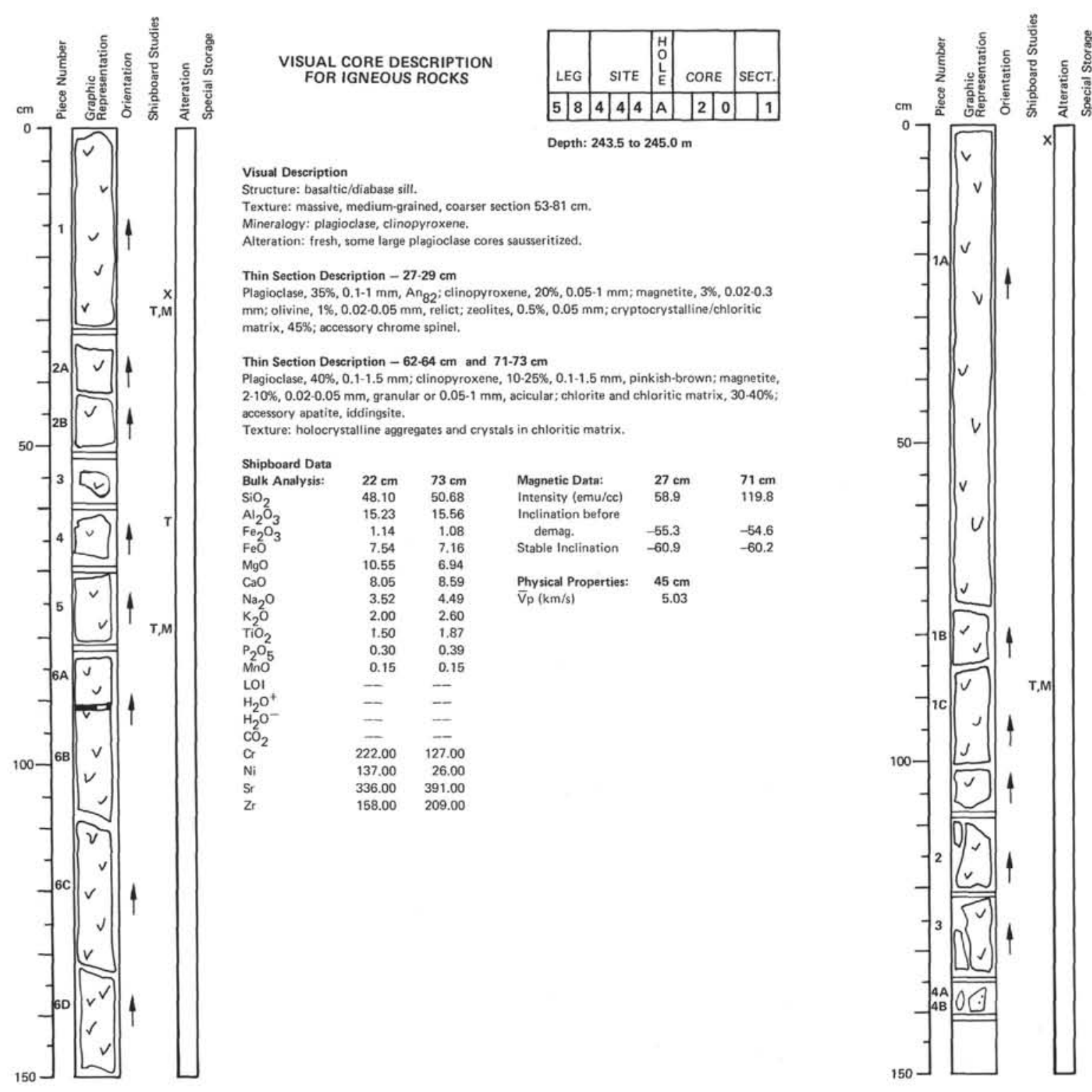
VISUAL CORE DESCRIPTION
FOR IGNEOUS ROCKS

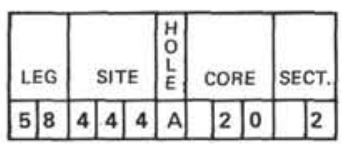

Depth: 245.0 to $246.4 \mathrm{~m}$

\section{Visual Description}

altic/diabase sill continued from previous section.

Texture: massive, medium-grained.

Alteration: fresh with talcose vein/tracture lining on Pieces 2 and 3 .

\section{Thin Section Description $-88.90 \mathrm{~cm}$}

Plagioclase, 33\%, 0.05-1 mm, >An 60 ; clinopyroxene, 20\%, 0.05-1 mm; olivine, 5\%, 0.05 . $0.2 \mathrm{~mm}$, relict; magnetite, $2 \%, 0.02 \cdot 0.1 \mathrm{~mm}$ granular, $0.01 \cdot 0.5 \mathrm{~mm}$ elongate aggregates: cryptocrystalline/chloritic matrix, $40 \%$; accessory apatite. Texture: intersertal agregates of plagioclase or plagioclase and clinopyroxene in chloritic

$\begin{array}{llll}\text { Shipboard Data } & & & \\ \mathrm{Bulk} \text { Analysiz: } & 0 \mathrm{~cm} & \text { Magnetic Data: } & 88 \mathrm{~cm} \\ \mathrm{SiO}_{2} & 47.78 & \text { Intensity (emu/cc) } & 27.0 \\ \mathrm{Al}_{2} \mathrm{O}_{3} & 15.87 & \text { Inclination before } & \\ \mathrm{Fe}_{2} \mathrm{O}_{3} & 1.13 & \text { demag. } & -26.2 \\ \mathrm{~F}^{2} \mathrm{O} & 7.44 & \text { Stable Inclination } & -51.9\end{array}$

$\mathrm{FeO}$

$\mathrm{MgO}$

$\mathrm{TiO}_{2}-1.37$

$\mathrm{P}_{2} \mathrm{O}_{5}$

$\mathrm{MnO}-0.1$

$\mathrm{H}_{2} \mathrm{O}^{+}$

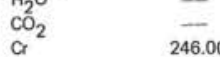

$\begin{array}{ll}\mathrm{Ni} & 246.00 \\ \mathrm{Si} & 295.00 \\ \mathrm{C} & 29600\end{array}$

Z. 14.00 

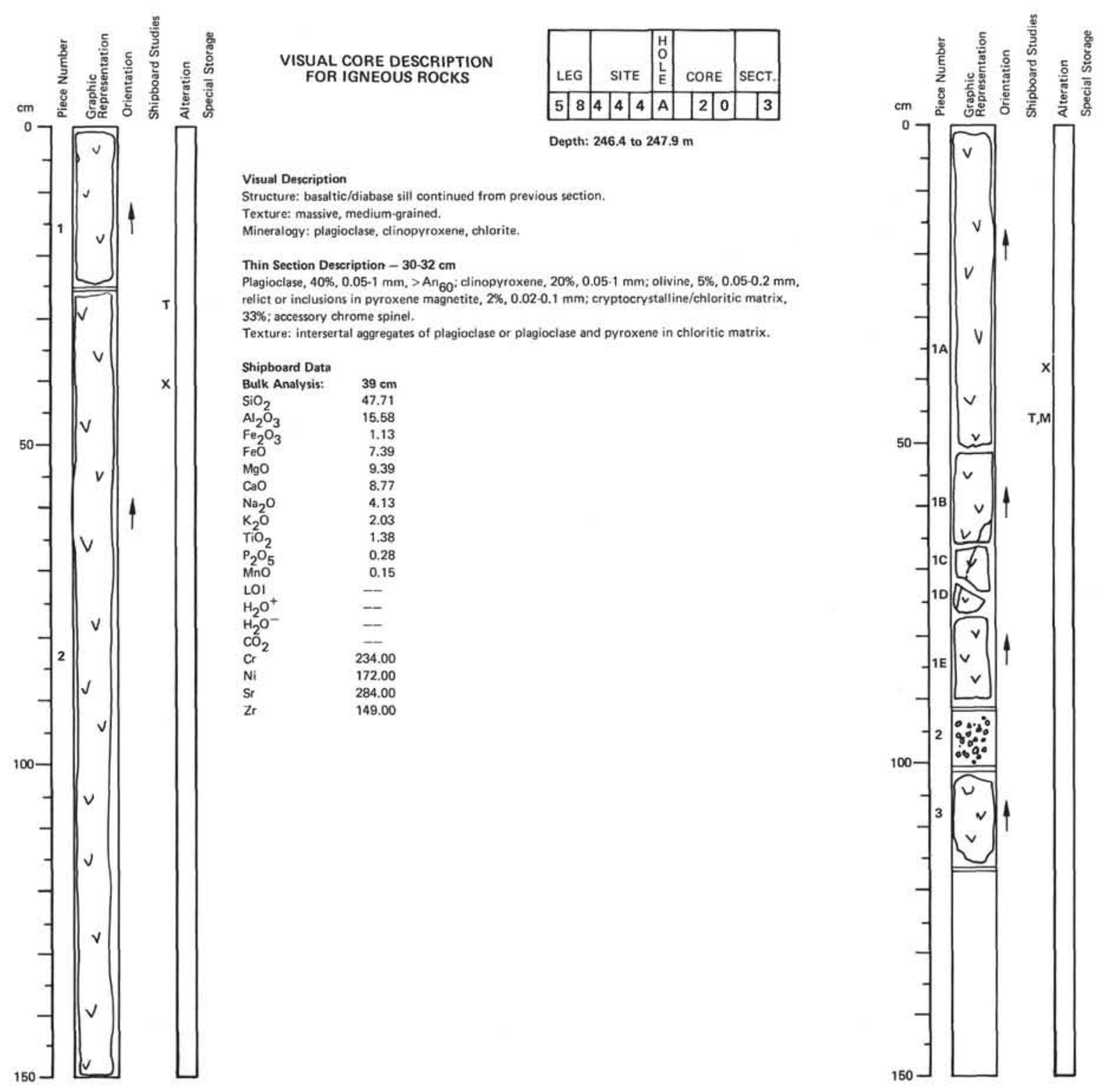 VISUAL CORE DESCRIPTION
FOR IGNEOUS ROCKS

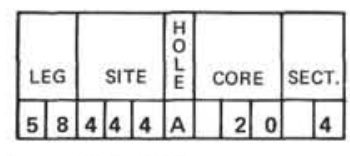
Depth: 247.9 to $249.1 \mathrm{~m}$

Visual Description

Structure: basaltic/diabase sill continued from previous section

Texture: massive, medium- to fine-grained.

Alteration: fresh appearance, talcose vein, $1 \mathrm{~mm}$ wide $63.75 \mathrm{~cm}$.

Thin Section Description $-46-48 \mathrm{~cm}$

Plagioclase, 25\%, 0.05-0.5 mm; clinopyroxene, 20\%, 0.05-0.5 mm, pinkish-brown; olivine, $15 \%, 0.05-0.3 \mathrm{~mm}$, relict: magnetite, $3 \%, 0.01-0.1 \mathrm{~mm}$ granular or $0.05-0.5 \mathrm{~mm}$ elonga oggregates; cryptocrystalline/chloritic matrix, 37\%; accessory chrome spinel, apatite,

Texture: in

: intersertal aggregates of plagioclase or plagioclase and clinopyroxene in chloritic matrix.

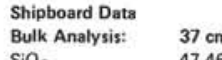

$\mathrm{SiO}_{2}$

$\mathrm{Al}_{2} \mathrm{O}_{3}$
$\mathrm{Fe}_{2} \mathrm{O}_{3}$
$\mathrm{FeO}^{2} \mathrm{O}$

${ }_{\mathrm{MgO}} \mathrm{O}$

$\mathrm{CaO}$

$\mathrm{Na}_{2} \mathrm{O}$

$\mathrm{P}_{2} \mathrm{O}_{5} \quad 0.22$

$\mathrm{H}_{\mathrm{H}_{2} \mathrm{O}^{+}}^{\mathrm{LOO}}=$

$\mathrm{H}_{2} \mathrm{O}^{-}$
$\mathrm{CO}_{2}$

$\begin{array}{ll}\mathrm{Cr}^{2} & 245.00 \\ \mathrm{Ni} & 182.00 \\ \mathrm{~N} & \mathrm{r}\end{array}$

$\begin{array}{lr}\mathrm{Sr} & 280.00 \\ \mathrm{Zr} & \quad 14500\end{array}$
Magnetic Data: 31.9 demag. 


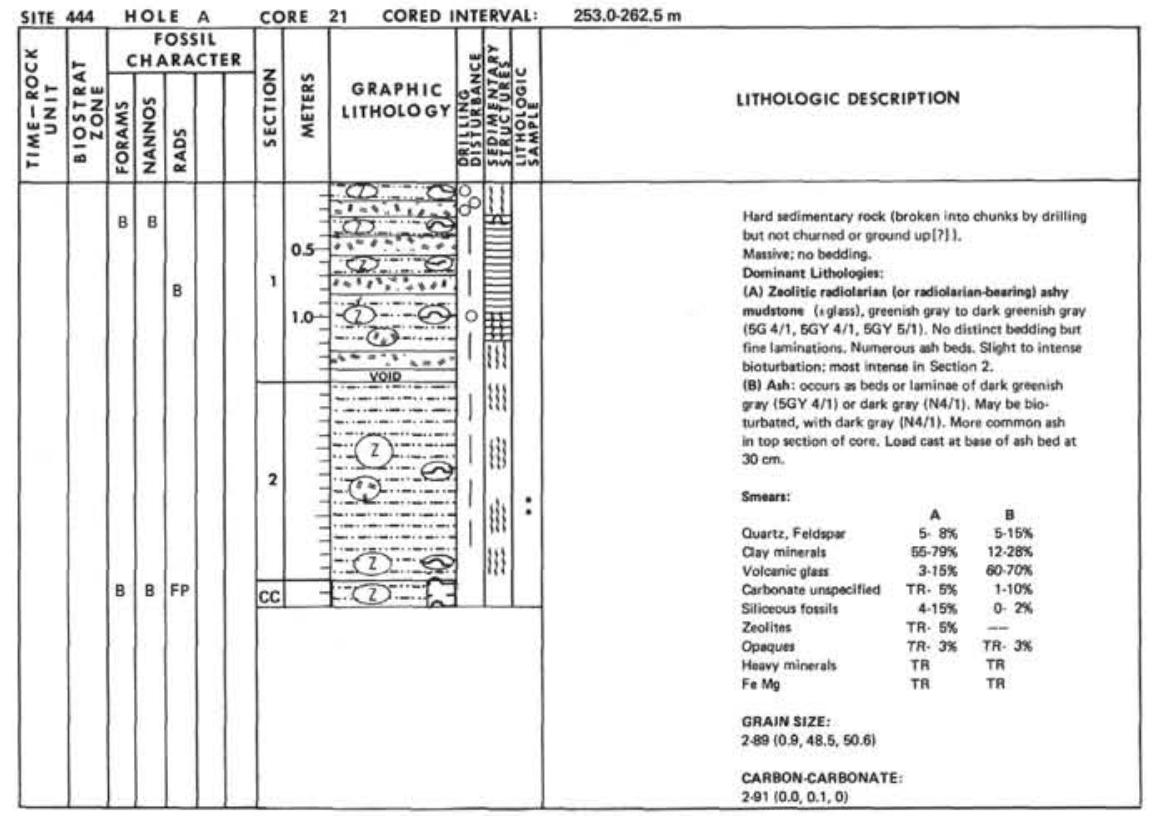

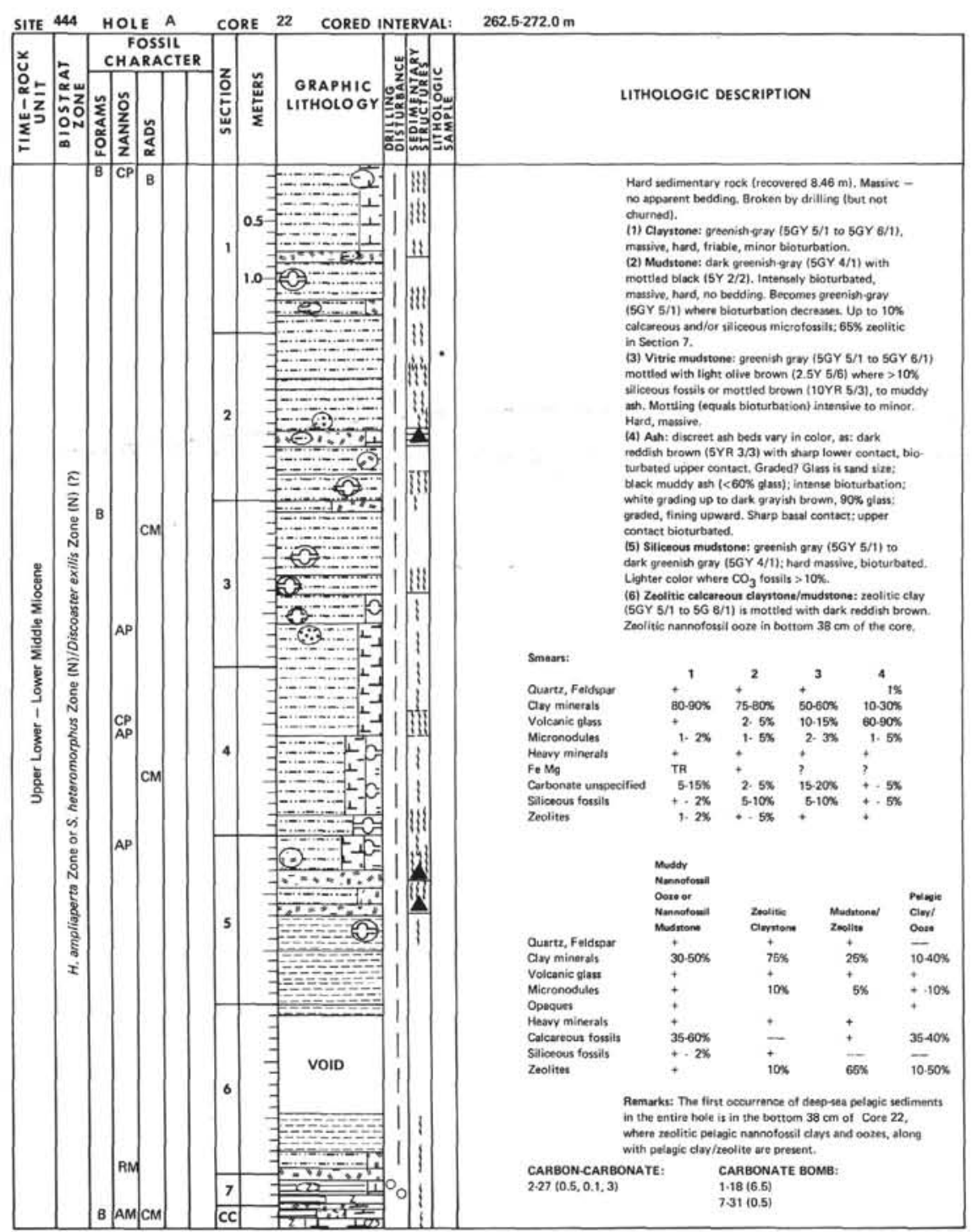




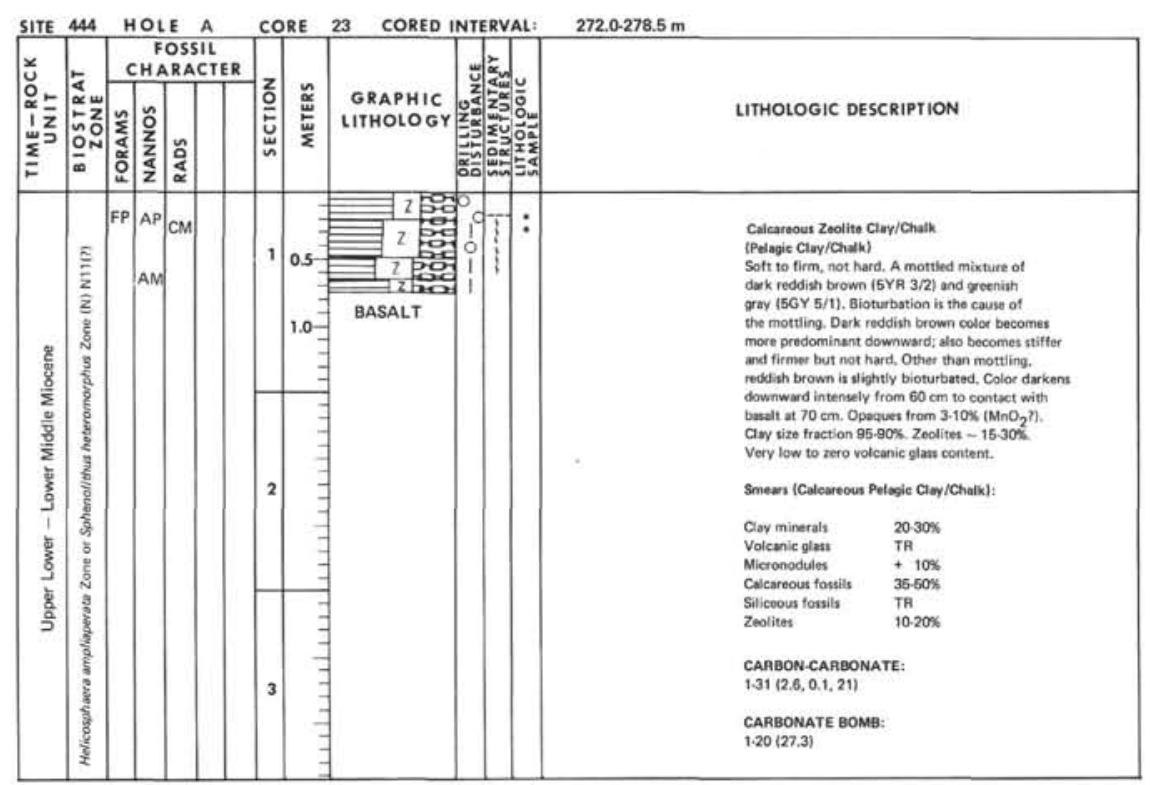



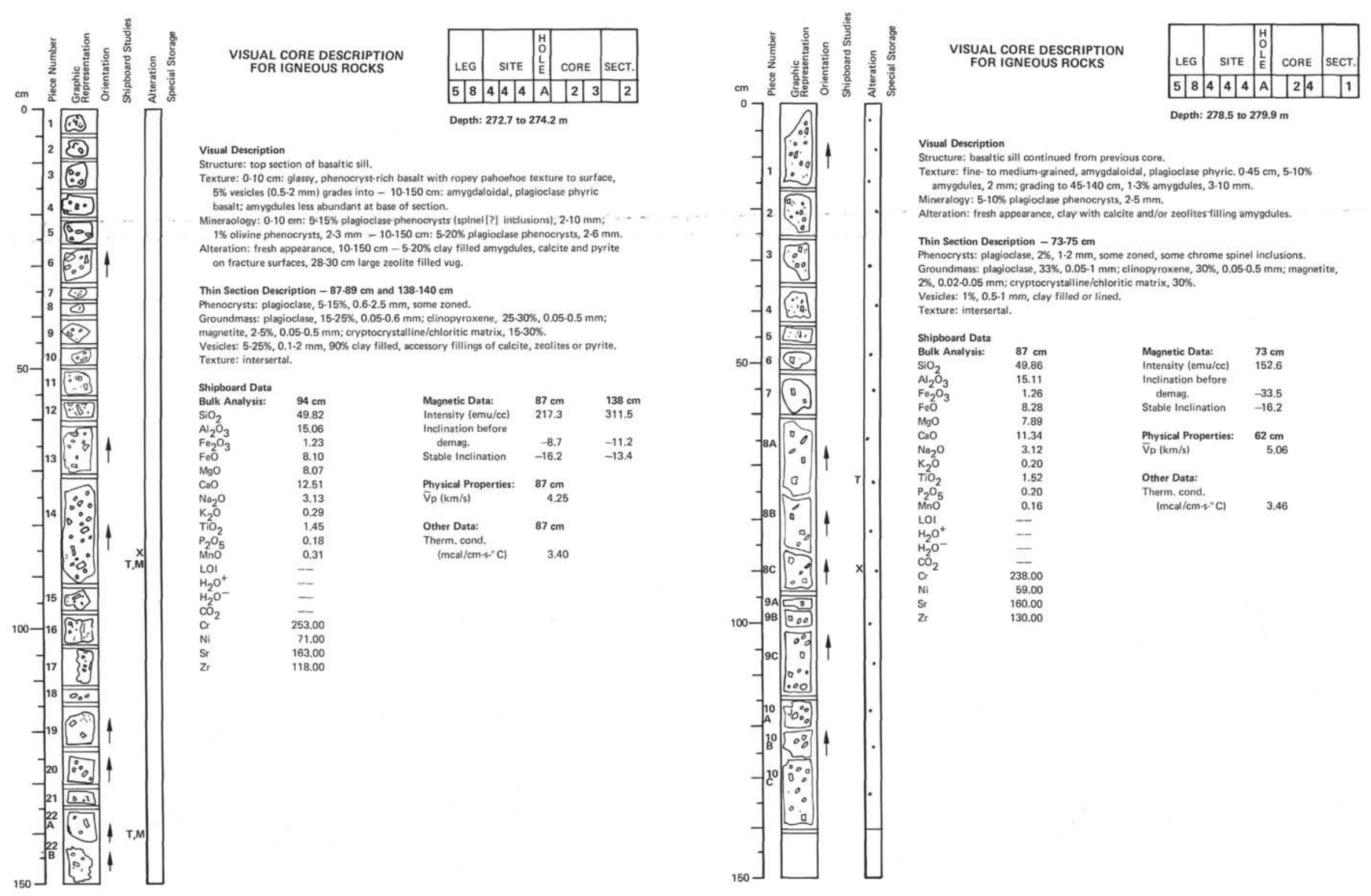

Visual Description

Structure: basal tic sill continued from previous core.

Texture: ina io

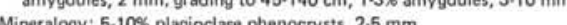

Alteration: tresh appearance, clay with calcite and/or

Thin Section Description $-73-75 \mathrm{~cm}$ (T) $2 \%, 0.02-0.05 \mathrm{~mm}$; cryptocrystalline/chloritic matrix, 30\%. Vesides: $1 \%, 0.5 .1 \mathrm{~mm}$, clay filled or lined. Texture: intersertal.

Shipboard Data
Bulk Analysis:

Bulk Anetris

$\begin{array}{ll}\mathrm{SiO}_{2} & 49.86 \\ \mathrm{Al}_{2} \mathrm{O}_{3} & 15.11\end{array}$

$\begin{array}{ll}\mathrm{Al}_{2} \mathrm{O}_{3} & 1.26 \\ \mathrm{Fe}_{2} \mathrm{O}_{3} & 1.11\end{array}$

$\begin{array}{ll}\mathrm{FeO}_{2} & 8.28 \\ \mathrm{MgO} & 7.89\end{array}$

$\mathrm{CaO}-11.34$

$\begin{array}{ll}\mathrm{Na}_{2} \mathrm{O} & 3.12 \\ \mathrm{~K}_{2} \mathrm{O} & 0.20\end{array}$

$\begin{array}{ll}\mathrm{K}_{2} \mathrm{O} & 0.20 \\ \mathrm{TiO}_{2} & 1.52\end{array}$

$\mathrm{MnO}_{2} \mathrm{P}^{2}-0.20$

$\mathrm{HOI}_{\mathrm{H}_{2} \mathrm{O}^{+}}$

$\mathrm{H}_{2} \mathrm{O}^{-}$

$\mathrm{CO}_{2} \quad-\overline{-}$

$\begin{array}{lr}\mathrm{Cr} & 238.00 \\ \mathrm{Ni} & 59.00 \\ \mathrm{ci} & 16000\end{array}$

$\begin{array}{ll}\mathrm{Sr} & 160.00 \\ \mathrm{Zr} & 130.00\end{array}$ 

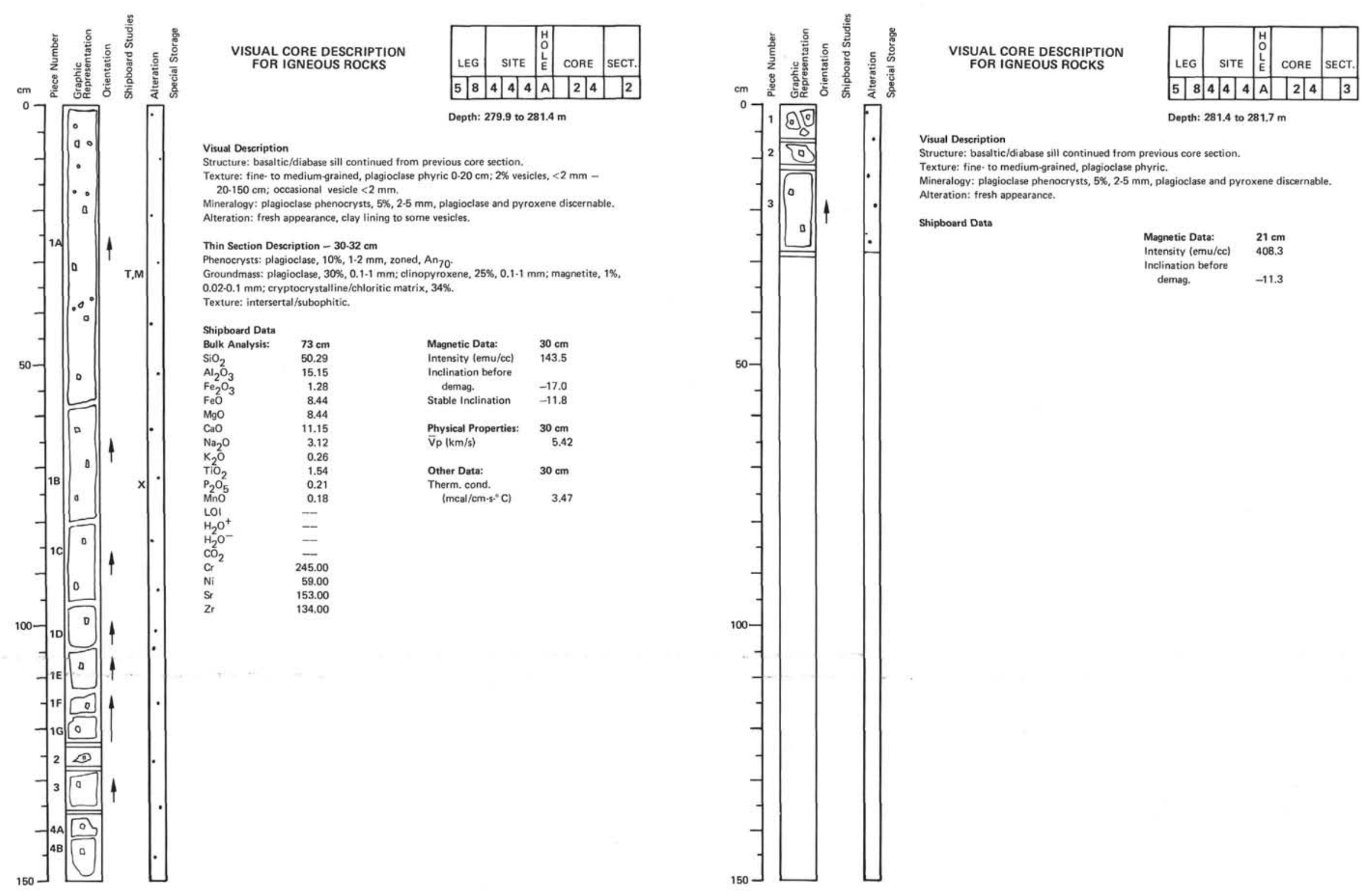

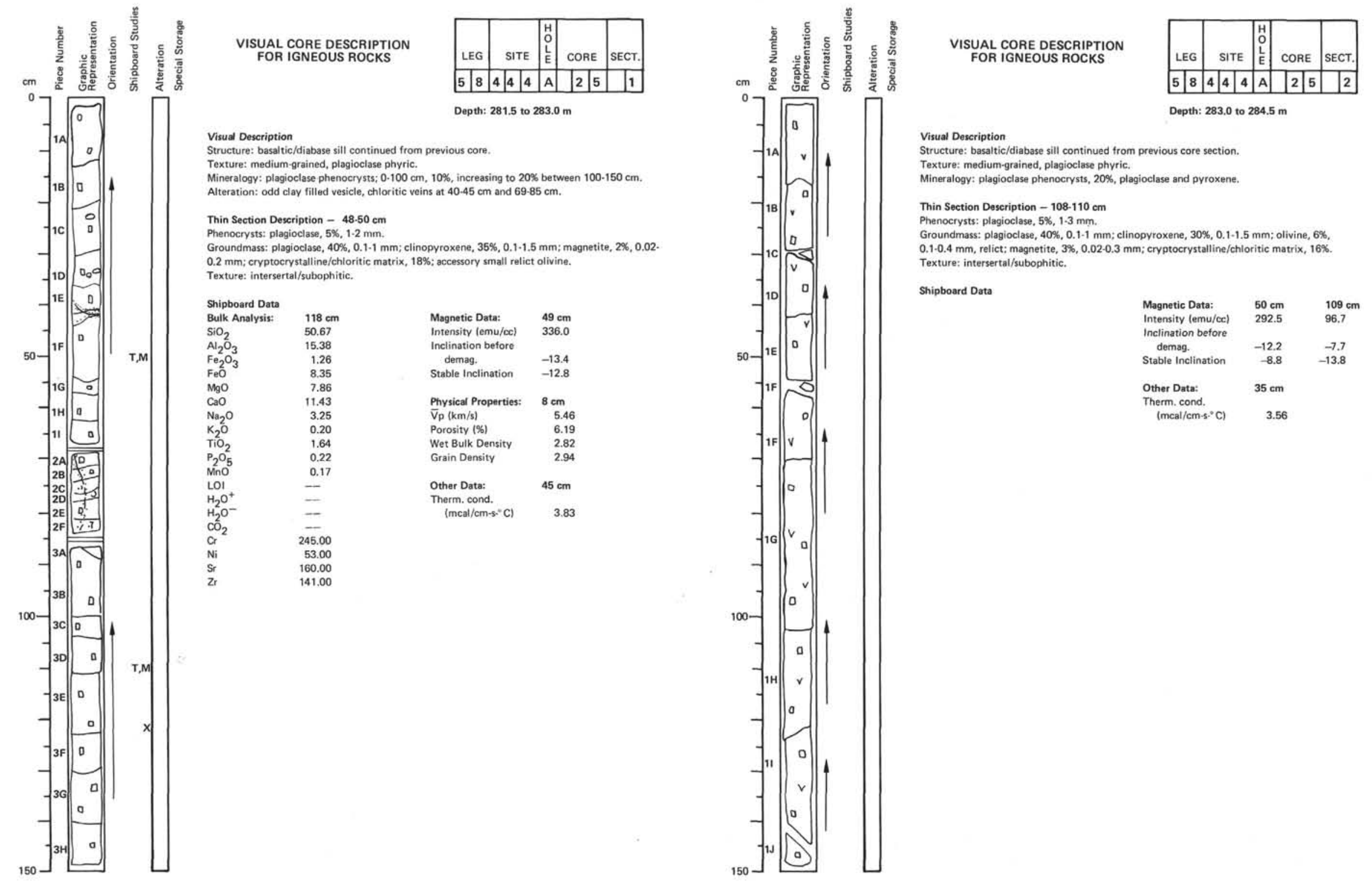

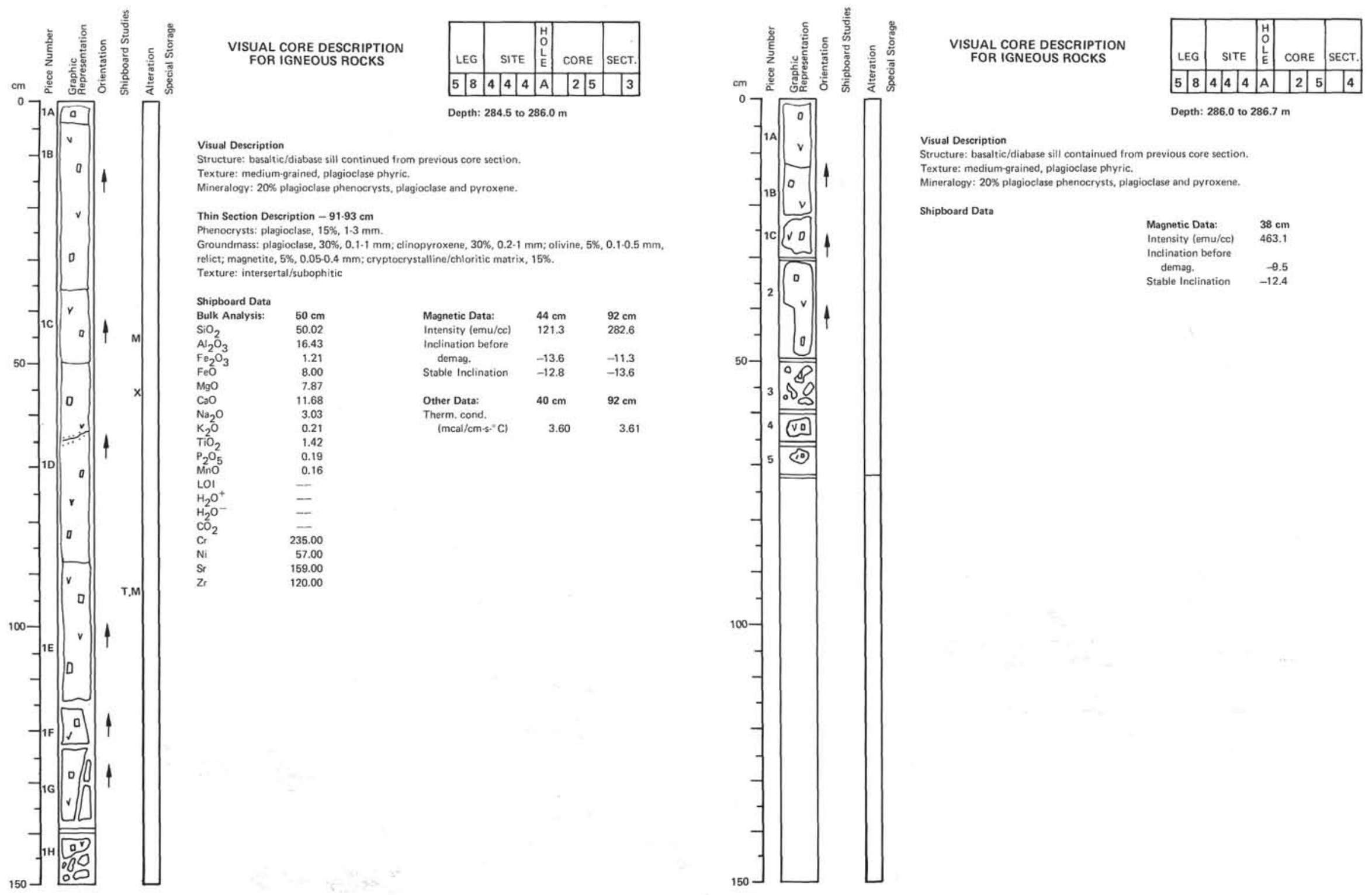

Visual Description

Structure: basaltic/diabase sill containued from previous core section. Mineralogy: $20 \%$ glaned, plagioclase phyric.

Shipboard Data

Magnetic Data: $38 \mathrm{~cm}$ Intensity temuical demag. Stable Inclination -0.5
-12.4 

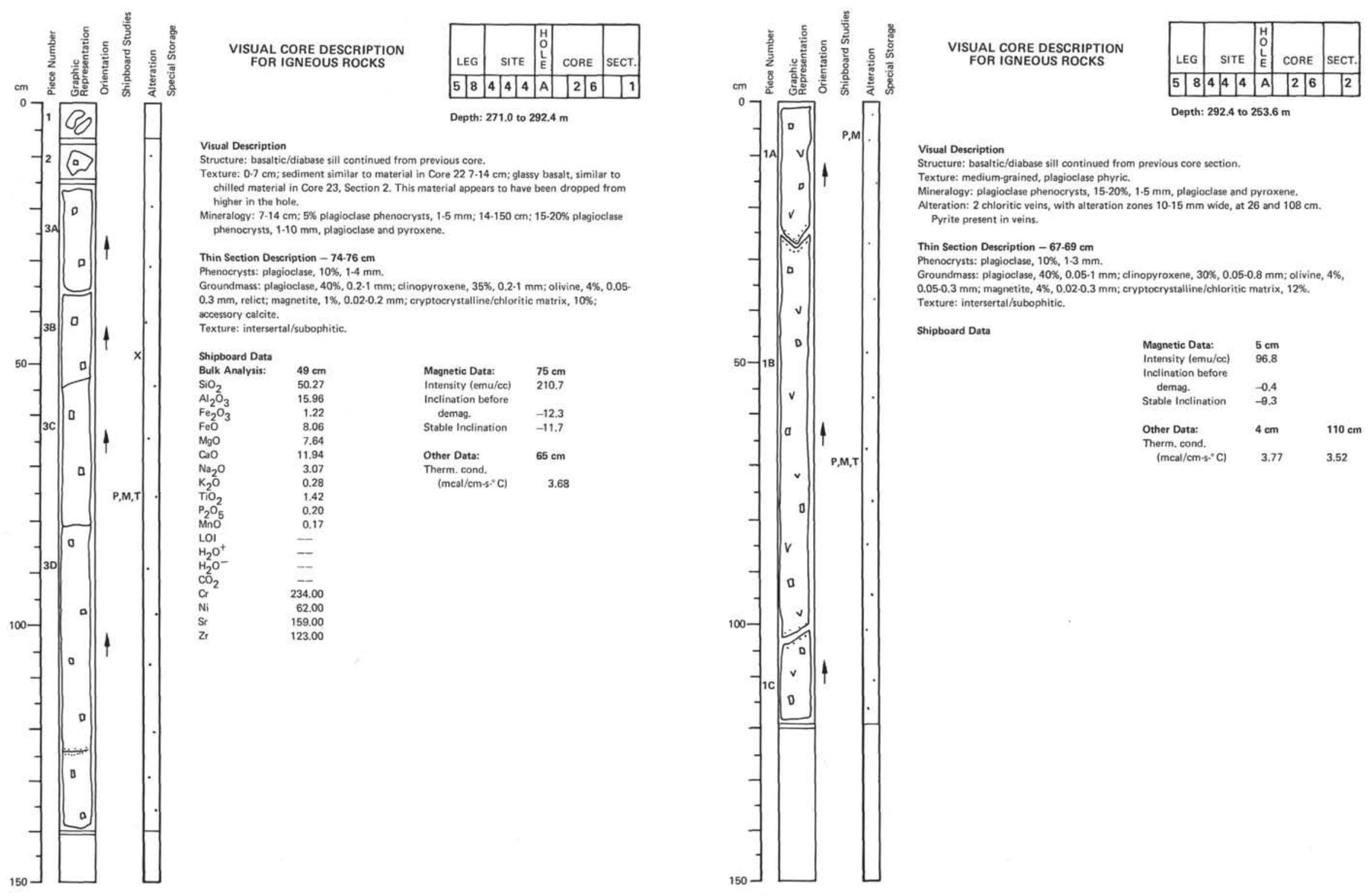

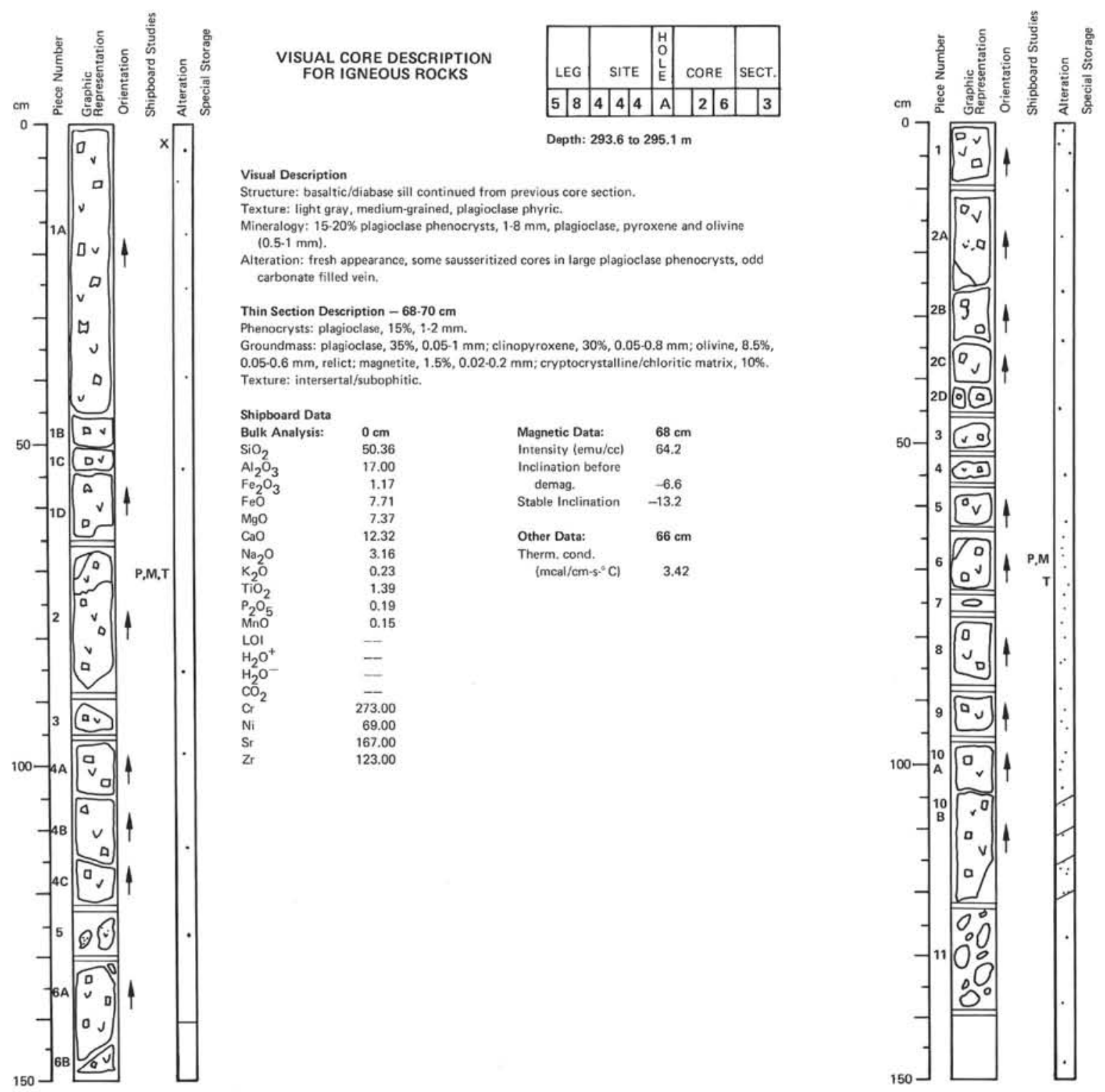
VISUAL CORE DESCRIPTION FOR IGNEOUS ROCKS

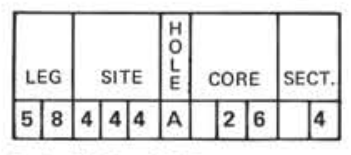
Depth: 295.1 to $296.5 \mathrm{~m}$

Visual Description

Structure: basaltic/diabase sill continued from previous care section.

Texture: light gray, medium-grained, plagioclase phyric.

Mineralogy: plagioclase phenocrysts, 15-20\%, 1.15 mm, plagioclase, pyroxene, odd

Olivine, $0.5-1 \mathrm{~mm}$.

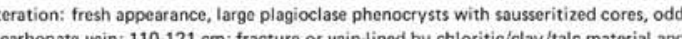
$\mathrm{cm}$; fracture or vein-lined by chloritic/clay/talc material and

\section{Thin Section Deseription $-63.65 \mathrm{~cm}$}

Phenocrysts: plagioclase, $30 \%, 1.10 \mathrm{~mm}$

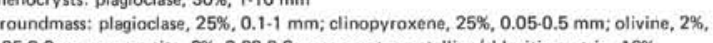
.050.2 mm, magnetite, $2 \%, 0.020$

Magnetic Data:

Intensity (emu/cc) $\quad 42.0$

Inclination befor

demag. -38.7 


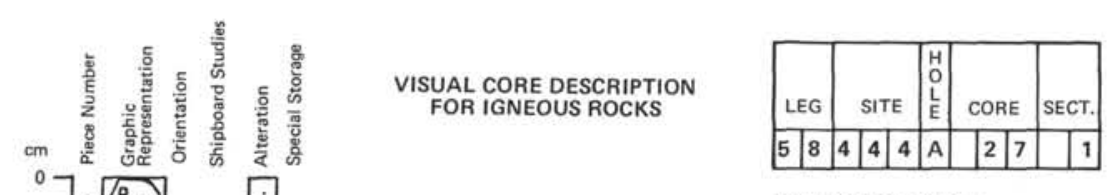

\section{Visual Description} Texture: light gray, medium grained, plagioclase Mineralogy: plagioclase phenocrysts, $15-20 \%, 1 \cdot 15 \mathrm{~mm}$; plagioclase, pyroxene, $0.5-1 \mathrm{~mm}$, Alteration: some susussertioxene grains.

\section{Thin Section Description $-90.92 \mathrm{~cm}$
Phenocrysts: plagioclase, $20 \%, 1-4 \mathrm{~mm}$} . cryptocrystalline/chloritic matrix, $20 \%$

$$
\text { Shipboard Data }
$$

\section{Magnetic Data:} Intensity (emu/oc) $\quad 46.4$

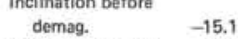
$\begin{array}{cc}\text { demag. } & -15.1 \\ \text { Stable } & \text {. }\end{array}$ Other Data: (mcal/cm-s." C) $90 \mathrm{~cm}$ 3.33

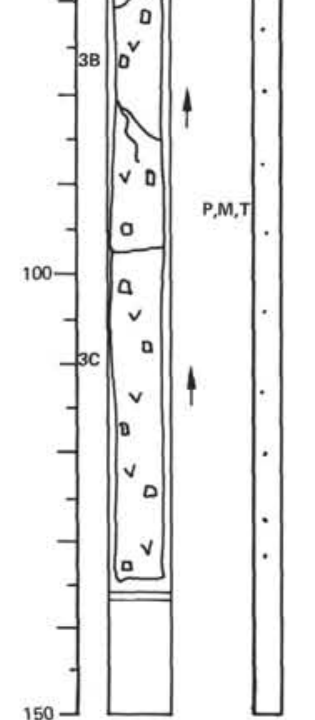

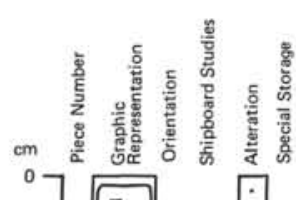

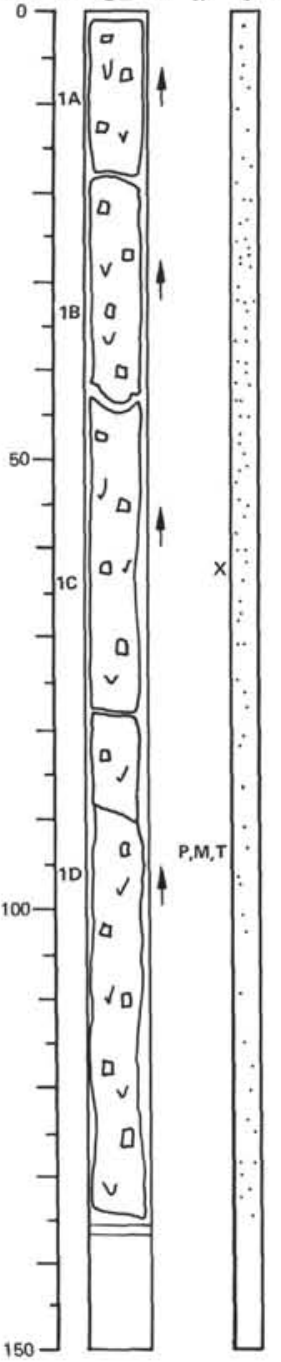

VISUAL CORE DESCRIPTION

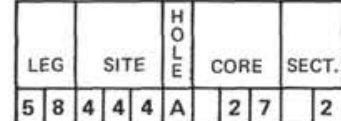

\section{Depth: 301.9 to $303.2 \mathrm{~m}$}

Visual Description

ase sill continued from previous core section.

Texture: light gray, medium-grained, plagioclase phyric.

. odd larger pyroxene and olivine grain.

teration: odd carbonate filled vein, carbonate and chlorite/clay-lined fractures at $44 \mathrm{~cm}$ and $79 \mathrm{cr}$

\section{Thin Section Description - $93.95 \mathrm{~cm}$}

refysts: plagioclase, $20 \%, 1.4 \mathrm{~mm}$. $0.05-0.1 \mathrm{~mm}$, relict; magnetite, $1 \%, 0.02-0.2 \mathrm{~mm}$; cryptocrystalline/chloritic matrix, $20 \%$. Texture: intersertal

\begin{tabular}{|c|c|c|c|}
\hline Shipboard Date & & & \\
\hline Bulk Analysis: & $62 \mathrm{~cm}$ & Magnetic Data: & \\
\hline & 49.08 & Intensity (emu/cc) & 51.9 \\
\hline $\mathrm{Al}_{2} \mathrm{O}_{3}$ & 15.95 & Inclination before & \\
\hline $\begin{array}{l}\mathrm{Fe}_{2} \mathrm{O}_{3} \\
\mathrm{FeO}\end{array}$ & 1.16 & demag. & -25.0 \\
\hline $\begin{array}{l}\mathrm{reO} \\
\mathrm{Mg} O\end{array}$ & $\begin{array}{l}7.67 \\
969\end{array}$ & Stable Inclination & -14.1 \\
\hline $\mathrm{CaO}$ & $\begin{array}{r}31.09 \\
11.02\end{array}$ & Other Data: & $90 \mathrm{~cm}$ \\
\hline $\mathrm{Na}_{2} \mathrm{O}$ & 3.09 & Therm. cond. & \\
\hline $\mathrm{K}_{2} \mathrm{O}$ & 0.39 & $\left(\mathrm{mcal} / \mathrm{cm}-\mathrm{s}^{\circ} \mathrm{C}\right)$ & 3.68 \\
\hline
\end{tabular}



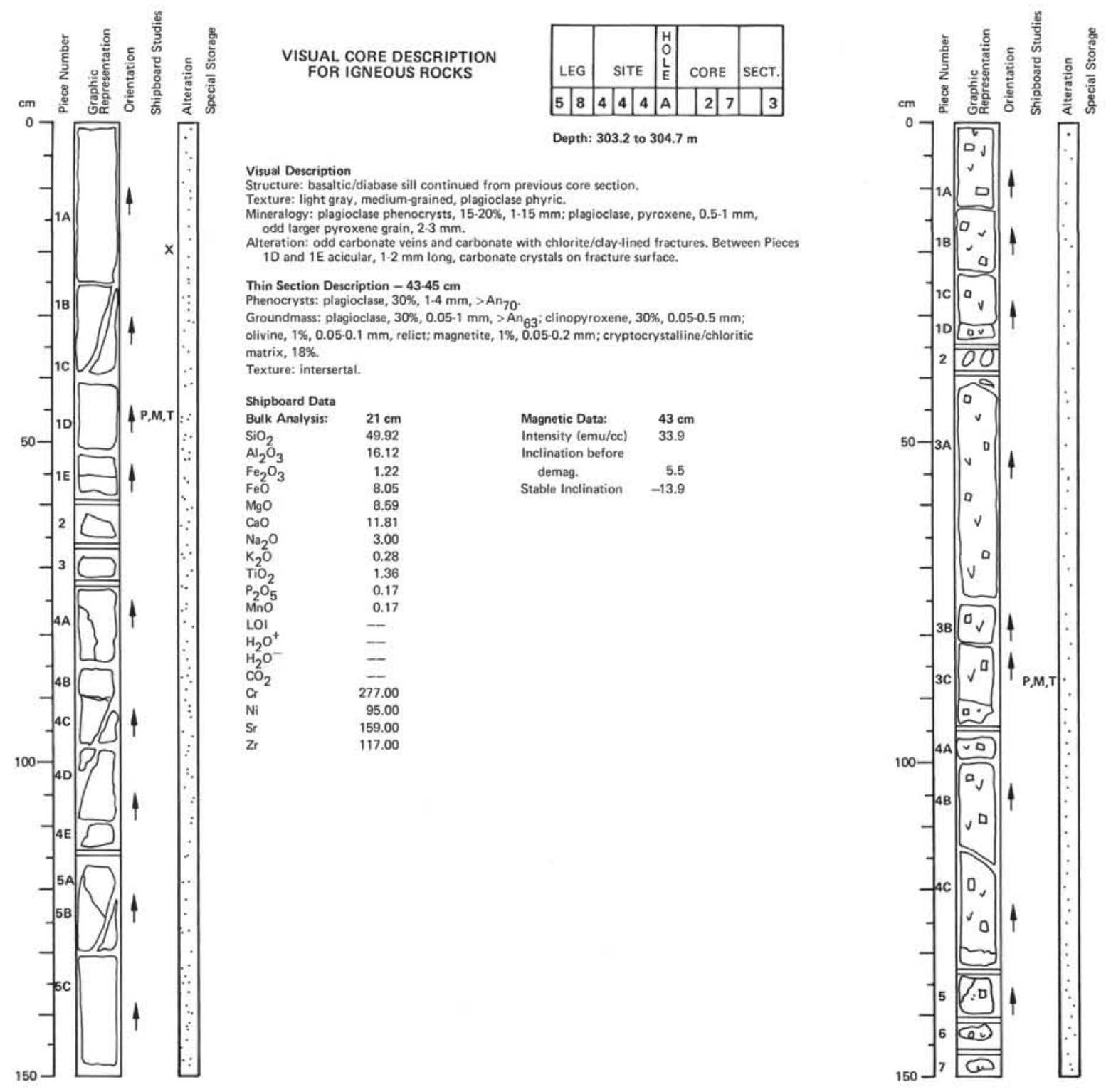

VISUAL CORE DESCRIPTION FOR IGNEOUS ROCKS

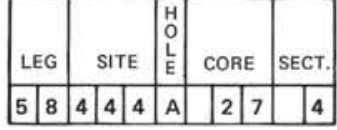

Depth: 304.7 to $306.2 \mathrm{~m}$

\section{Visual Description}

STuture. basalic/liabase sill continued from previous cor

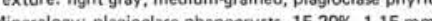

. $0.5-1 \mathrm{~mm}$ fractured.

Thin Section Description - $83-85 \mathrm{~cm}$

Phenocrysts. plagioclase, $15 \%, 1-3 \mathrm{~mm}$.

, 0.05-0.5 mm; olivine, $1 \%$ . $01-0.1 \mathrm{~mm}$; cryptocrystalline/chloritic matrix, $18 \%$ Texture: intersertal.

Shipboard Data

\begin{tabular}{|c|c|}
\hline $\begin{array}{l}\text { Magnetic Data: } \\
\text { Intensity (emu/cc) } \\
\text { Inclination before } \\
\text { demag. }\end{array}$ & $\begin{array}{l}83 \mathrm{~cm} \\
394\end{array}$ \\
\hline sble It & $-1 c$ \\
\hline & \\
\hline (k) & \\
\hline ros & 36 \\
\hline t 8 & \\
\hline Grain Denst & 2. \\
\hline & \\
\hline . & 3.6 \\
\hline
\end{tabular}




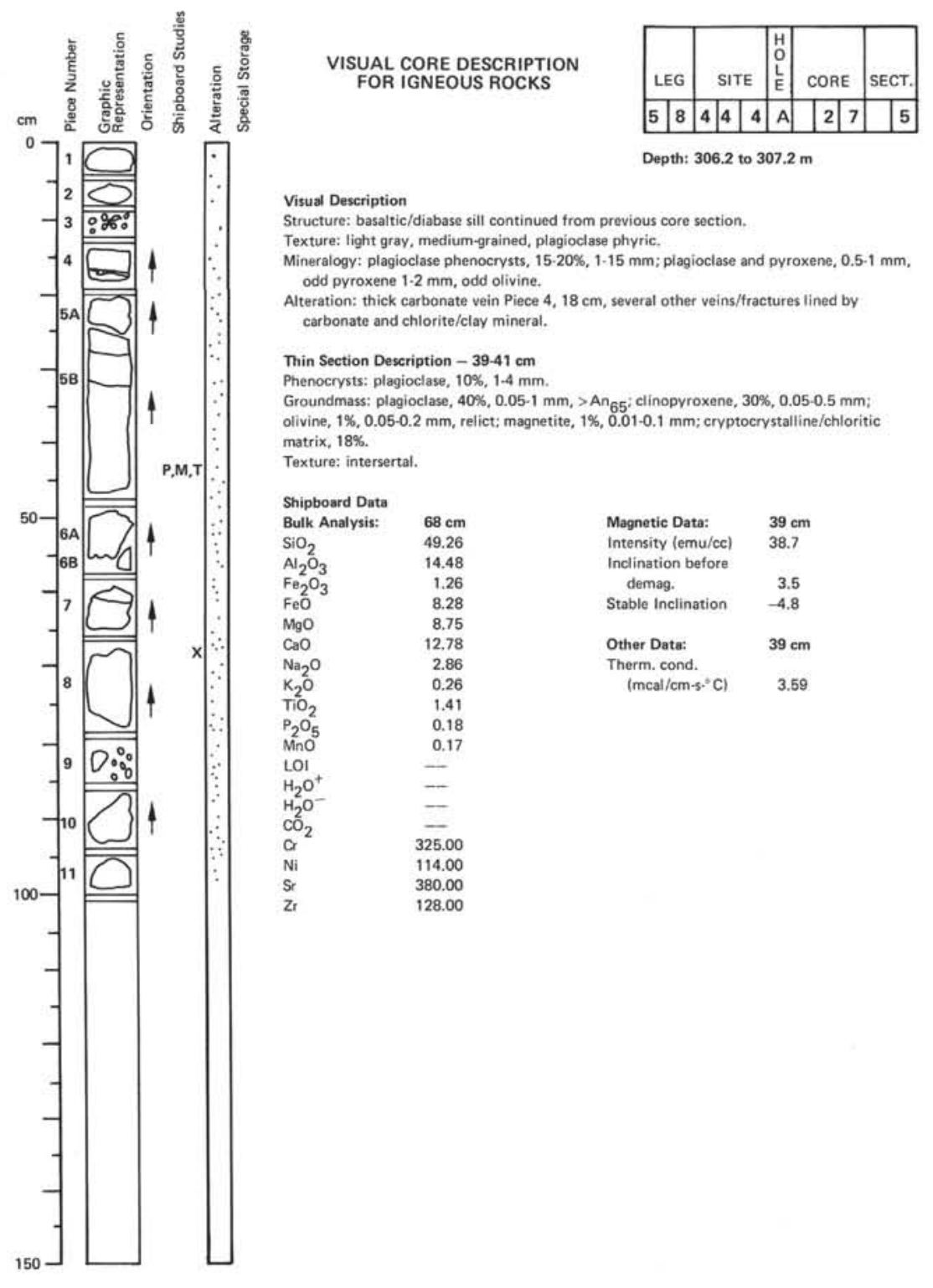




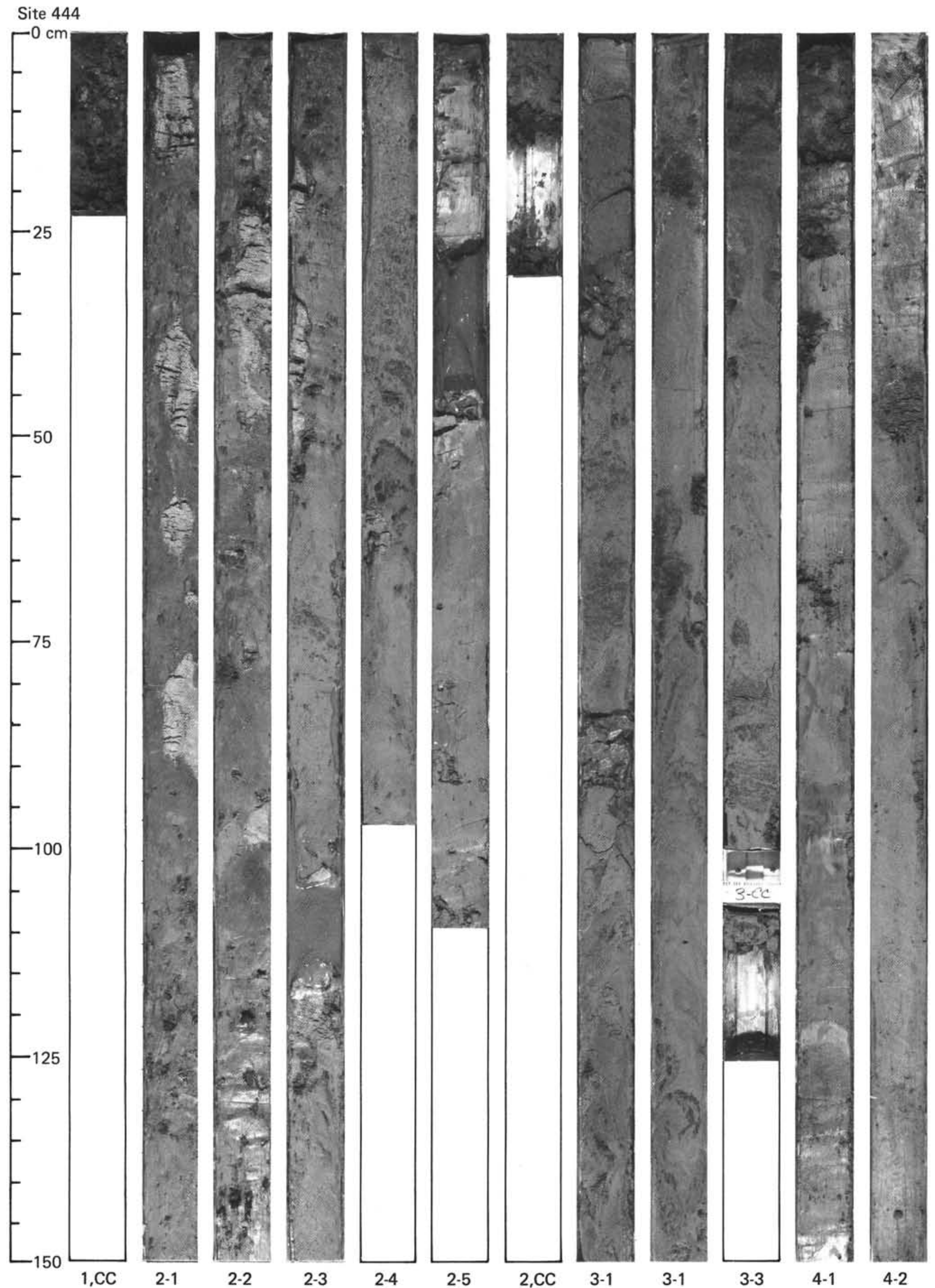




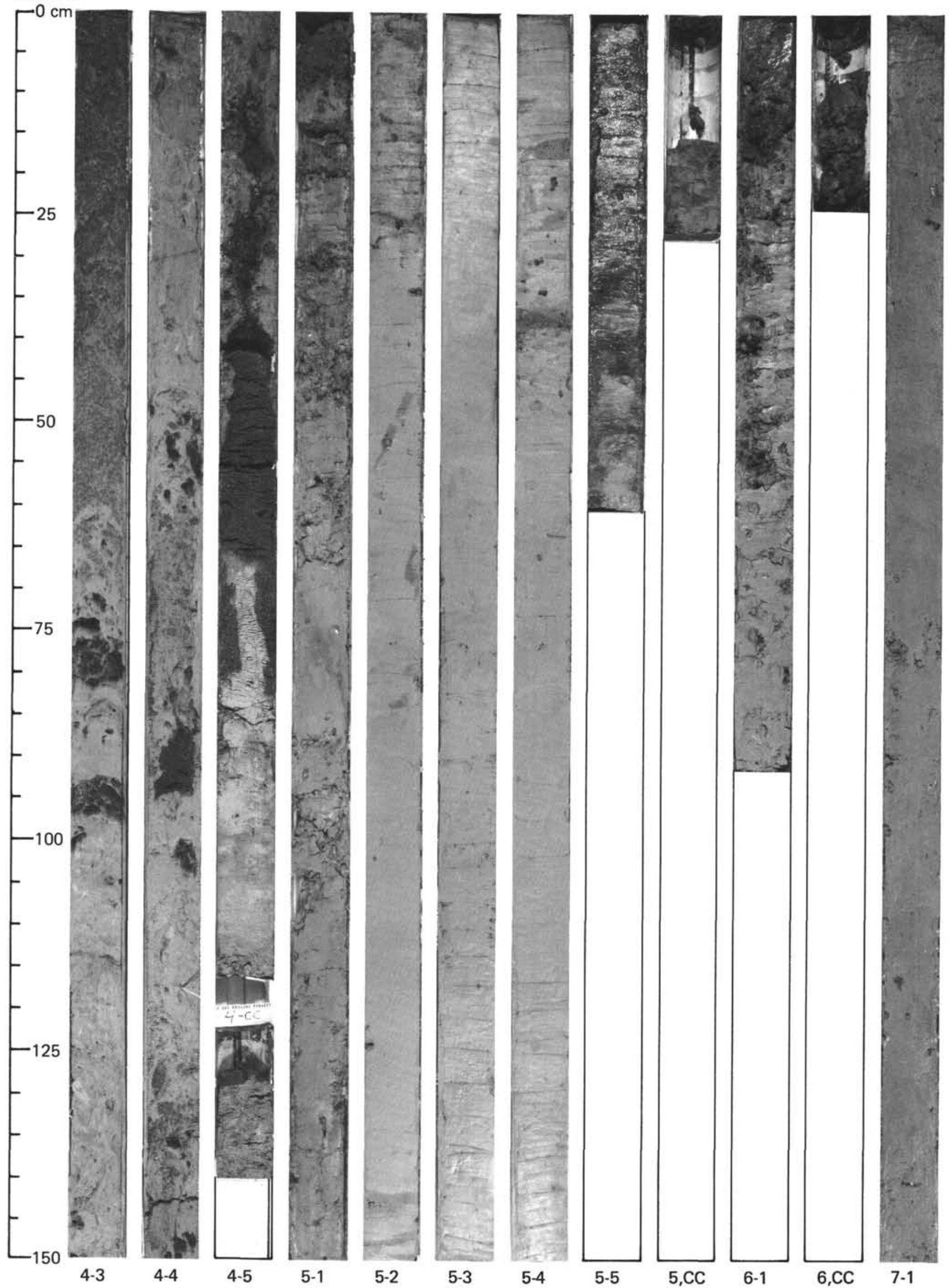




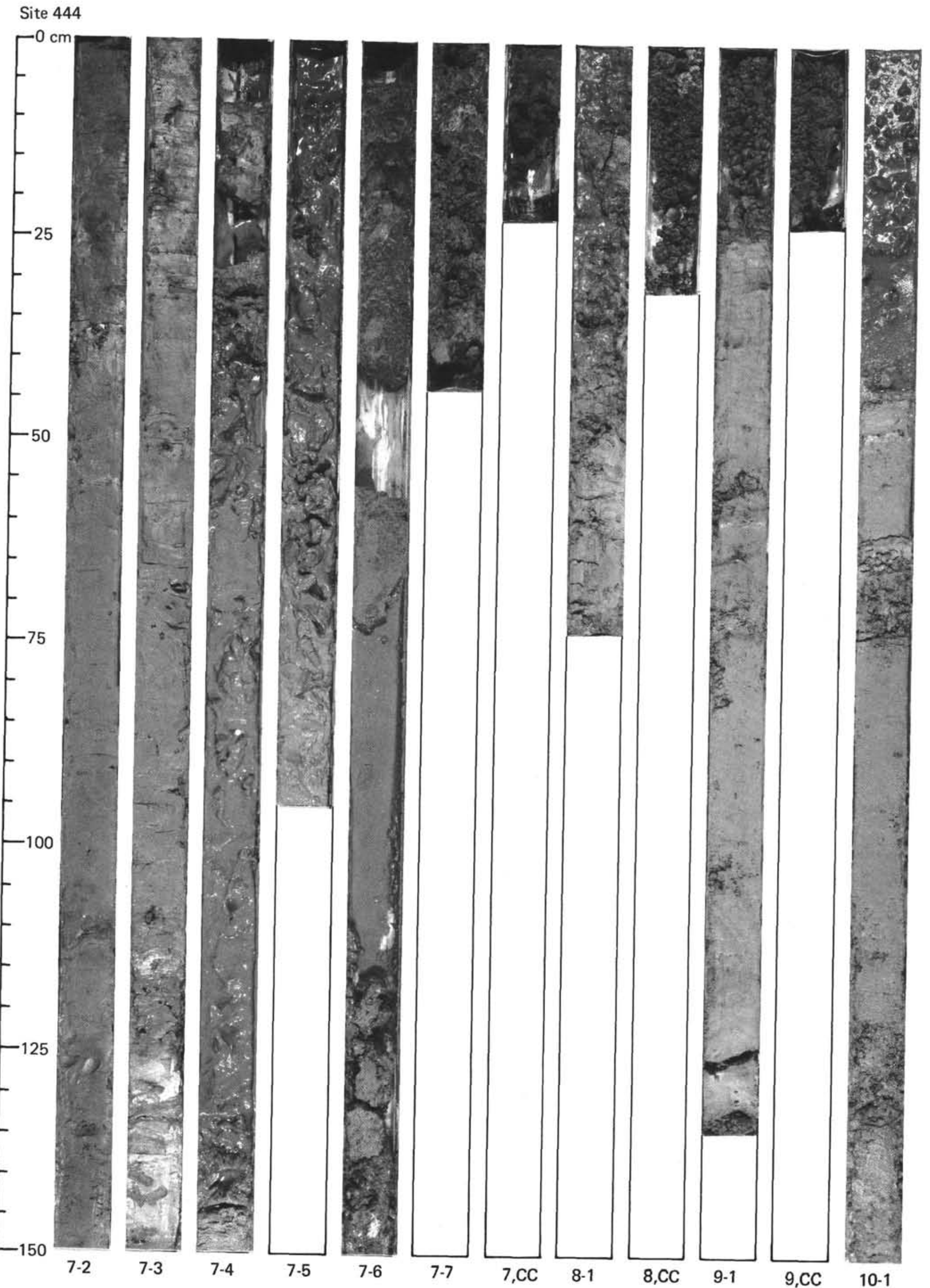


Site 444

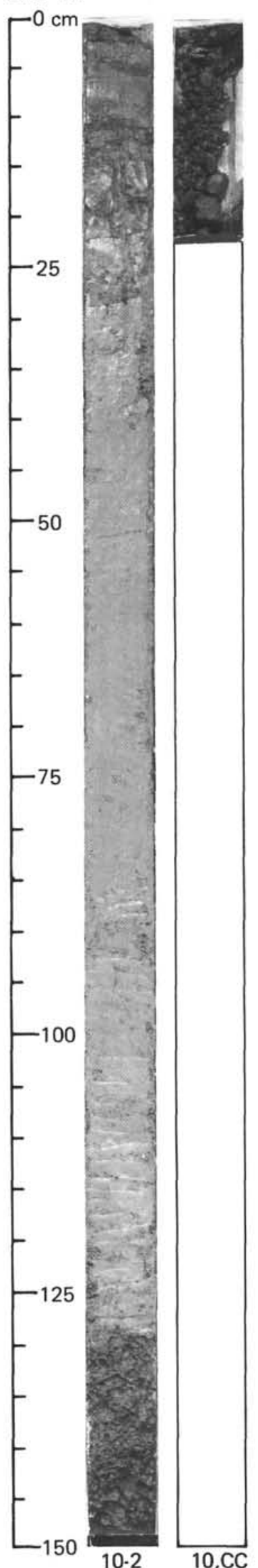




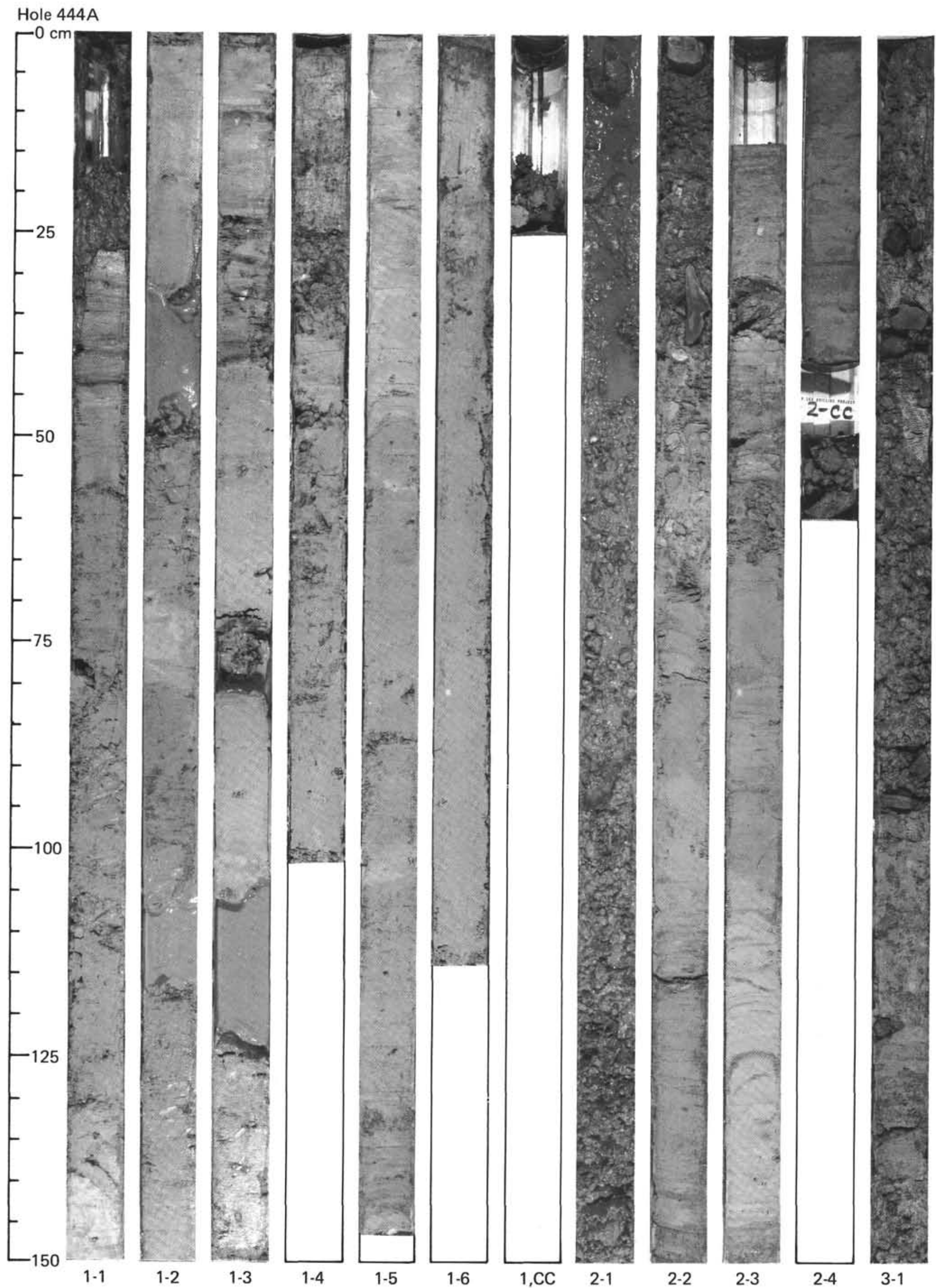


Hole 444A
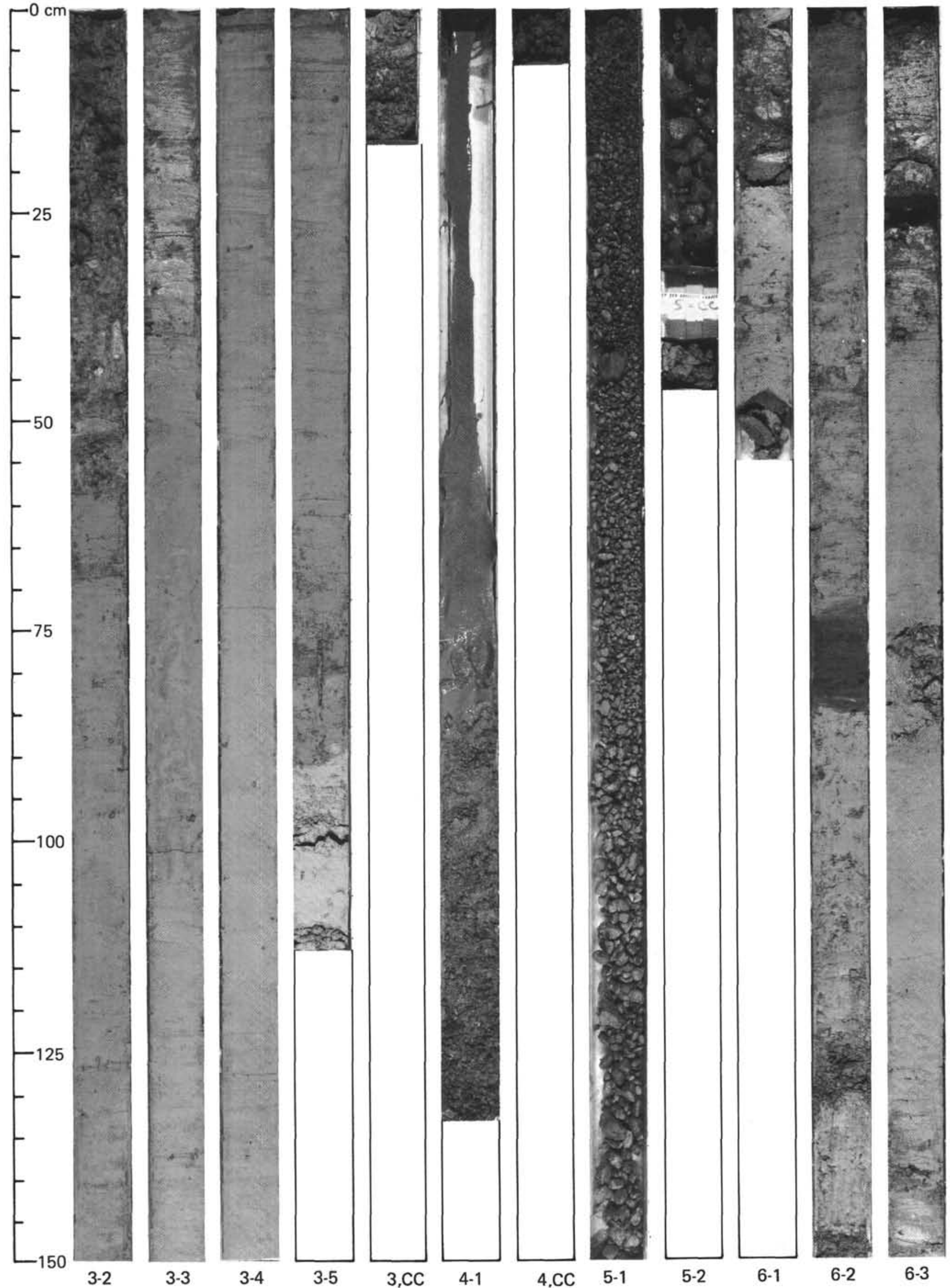


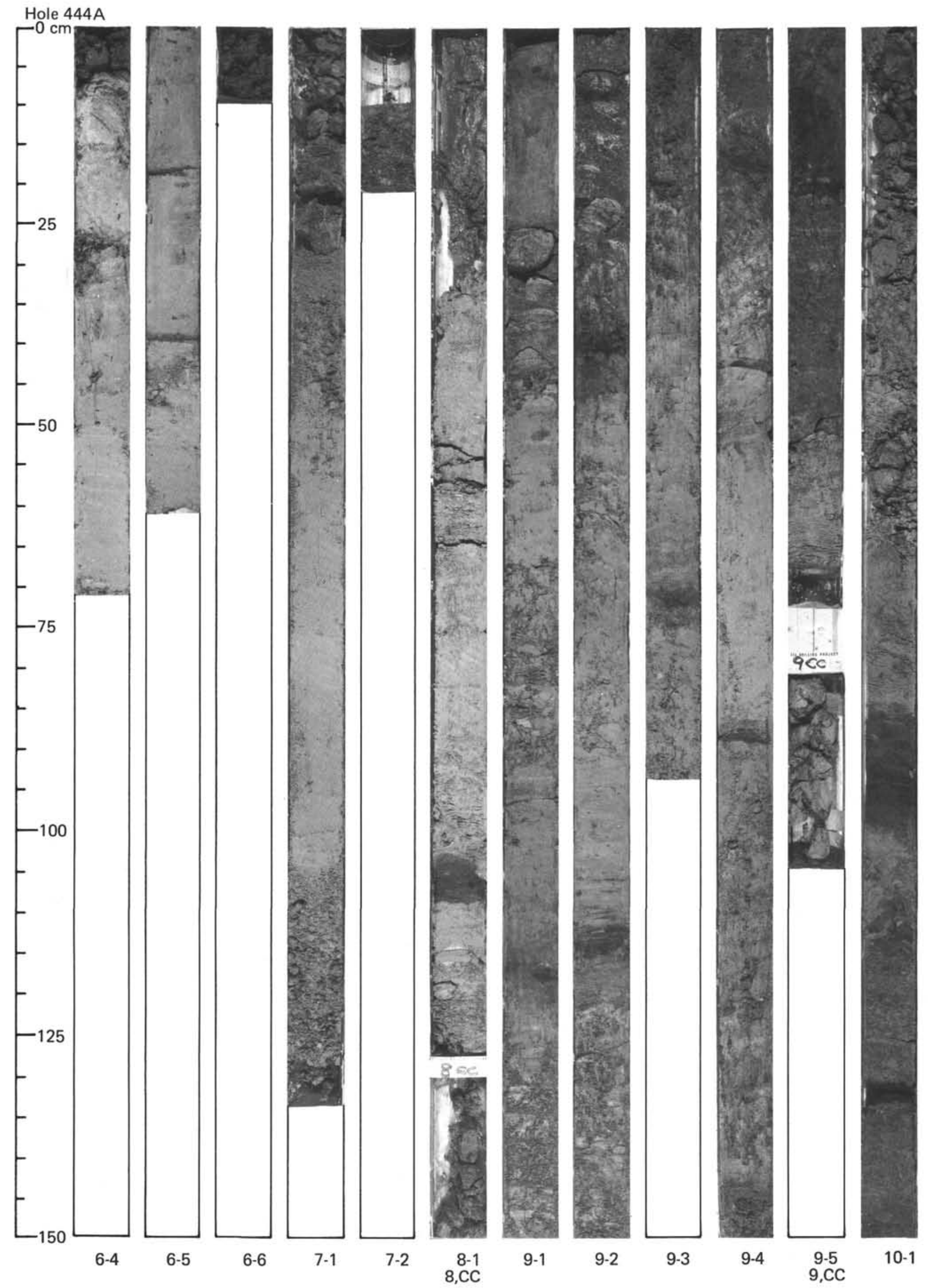



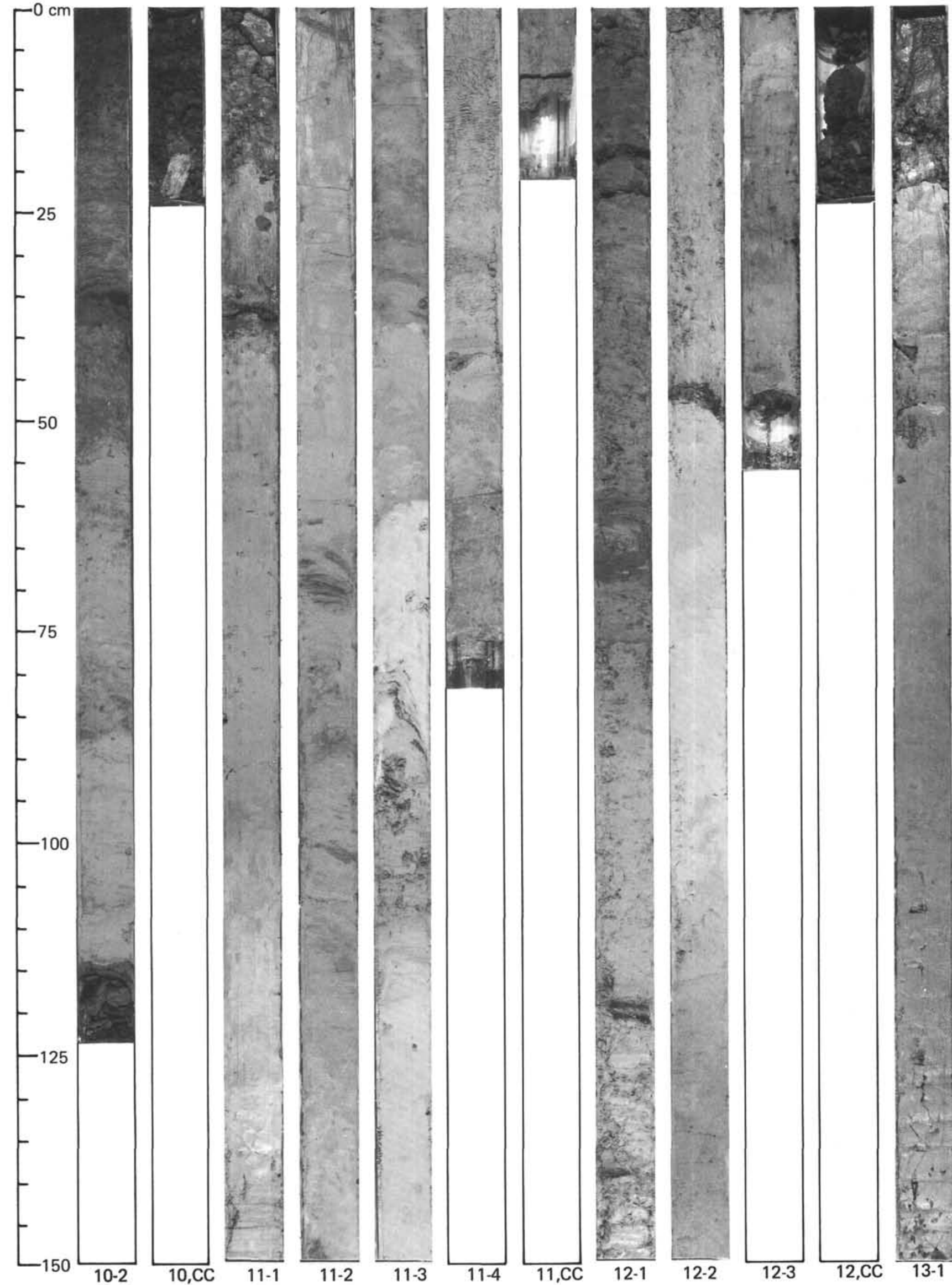
Hole 444A

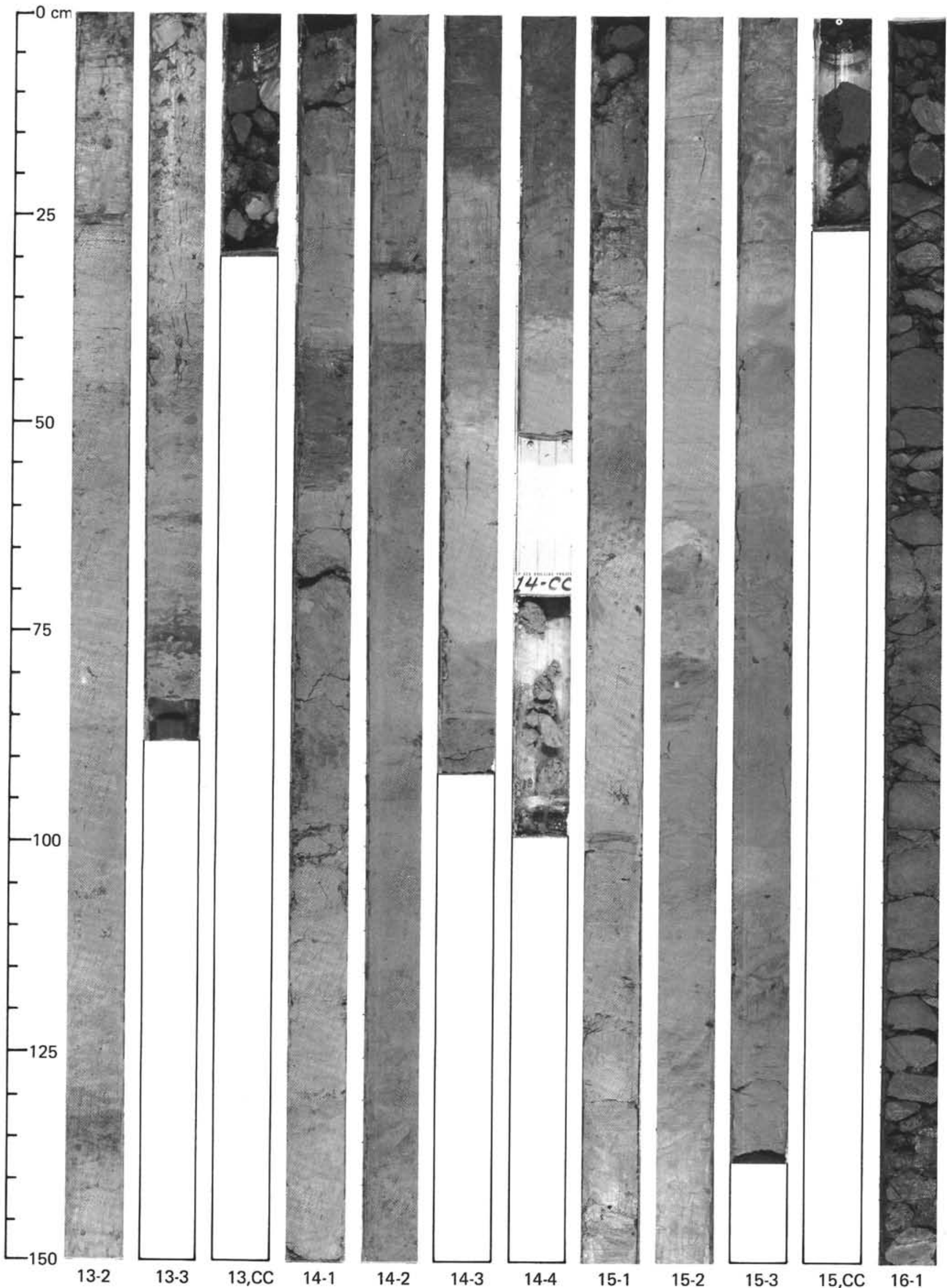


Hole 444A

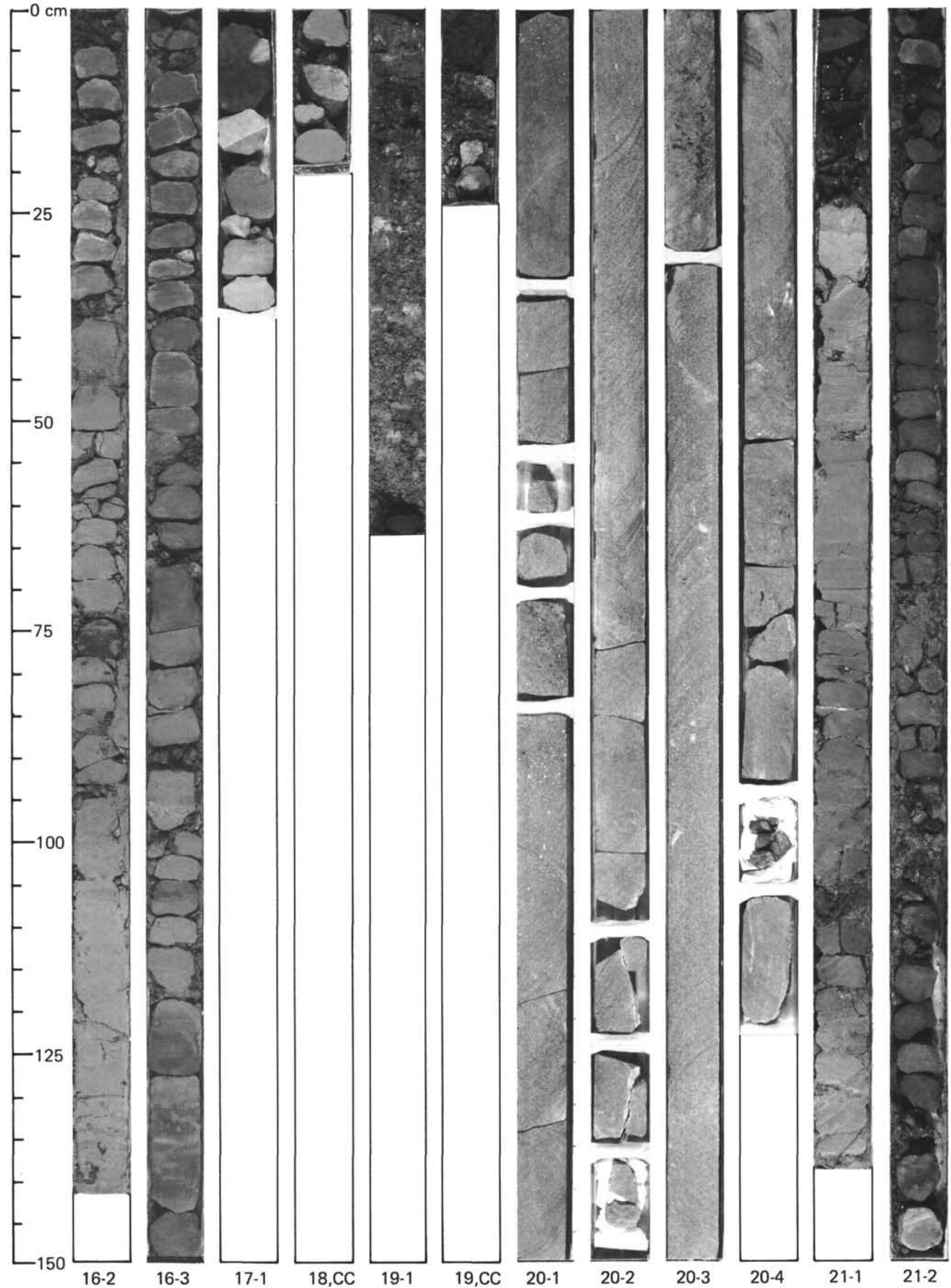


SITE 444

Hole 444A
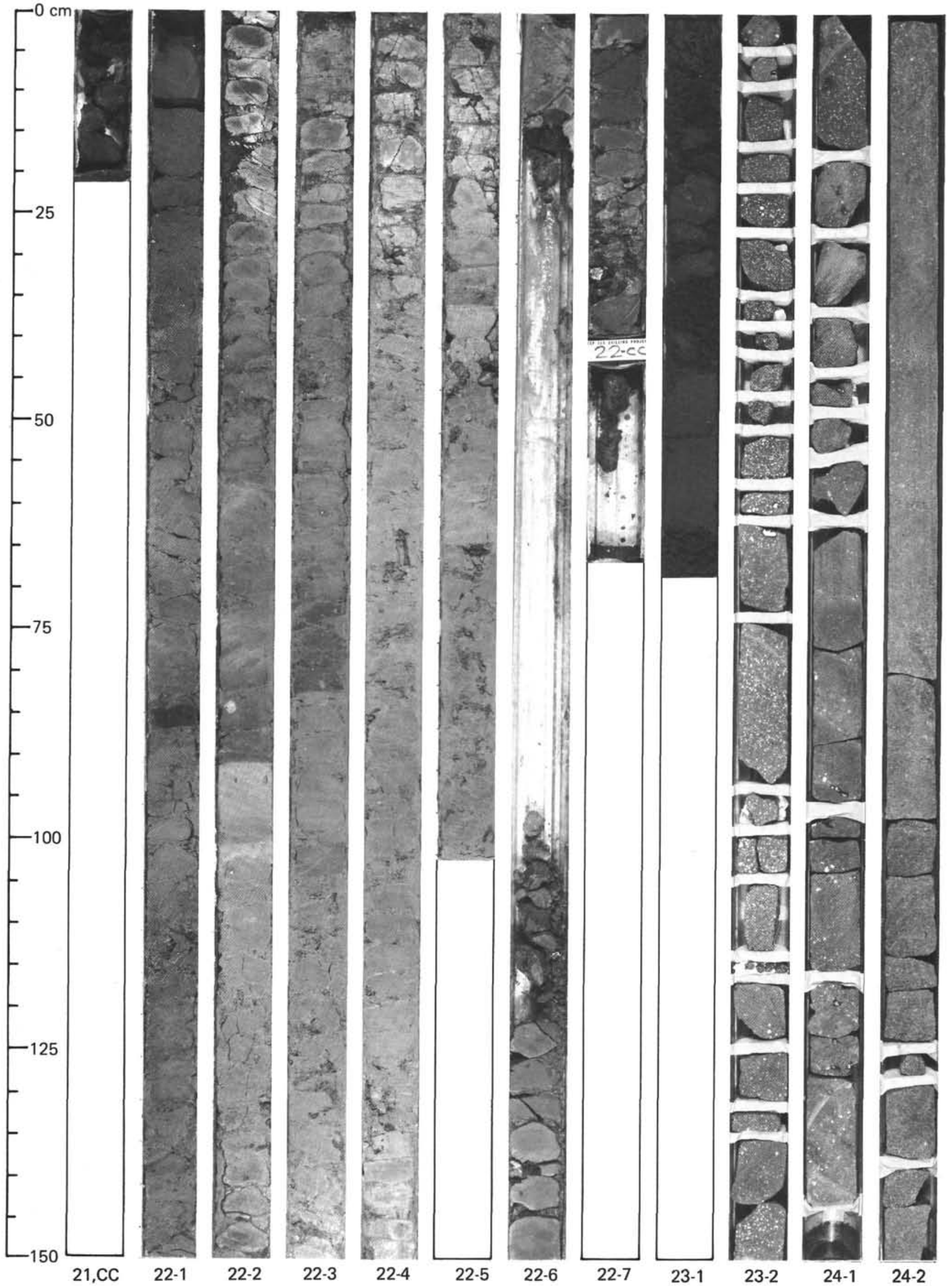

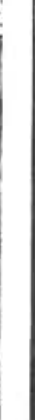
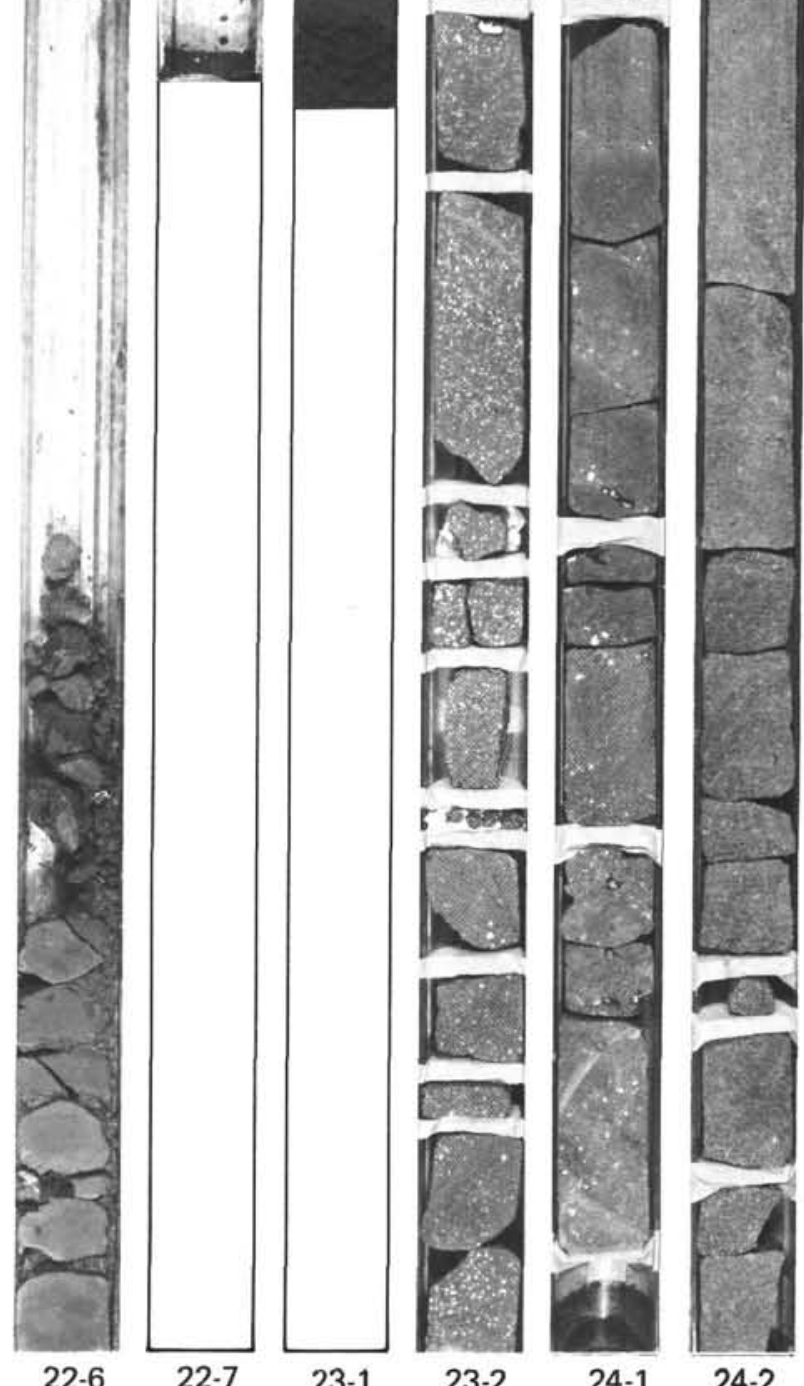
Hole 444A

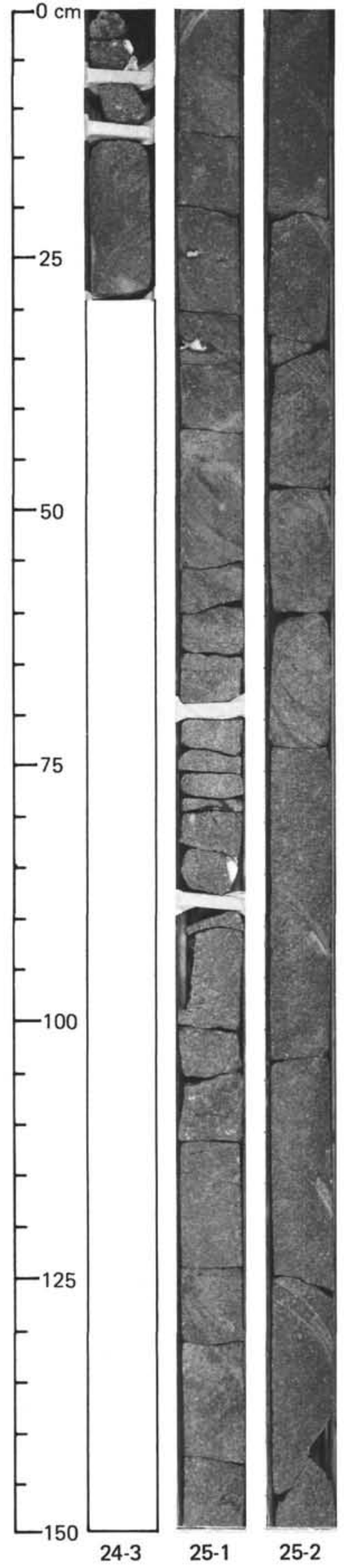

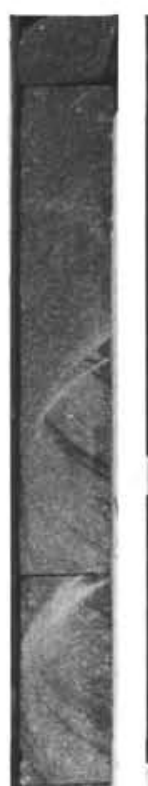
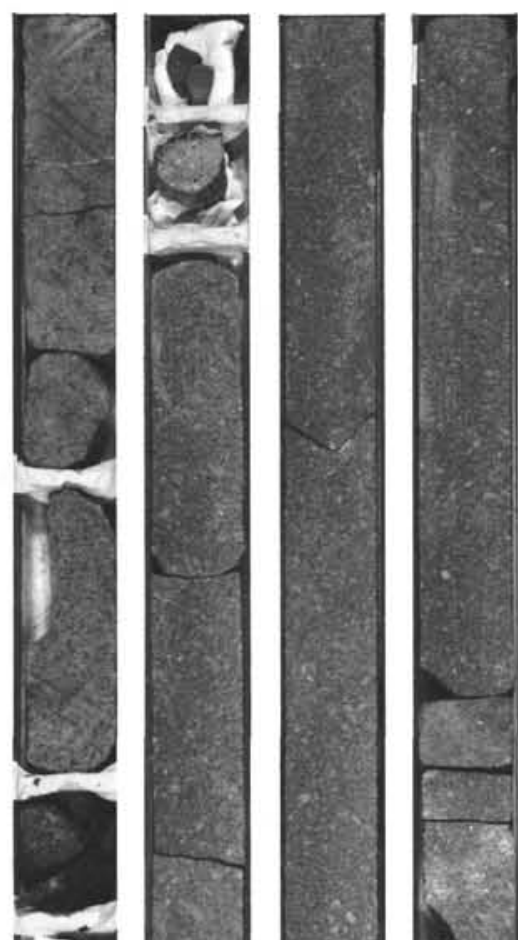

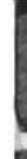
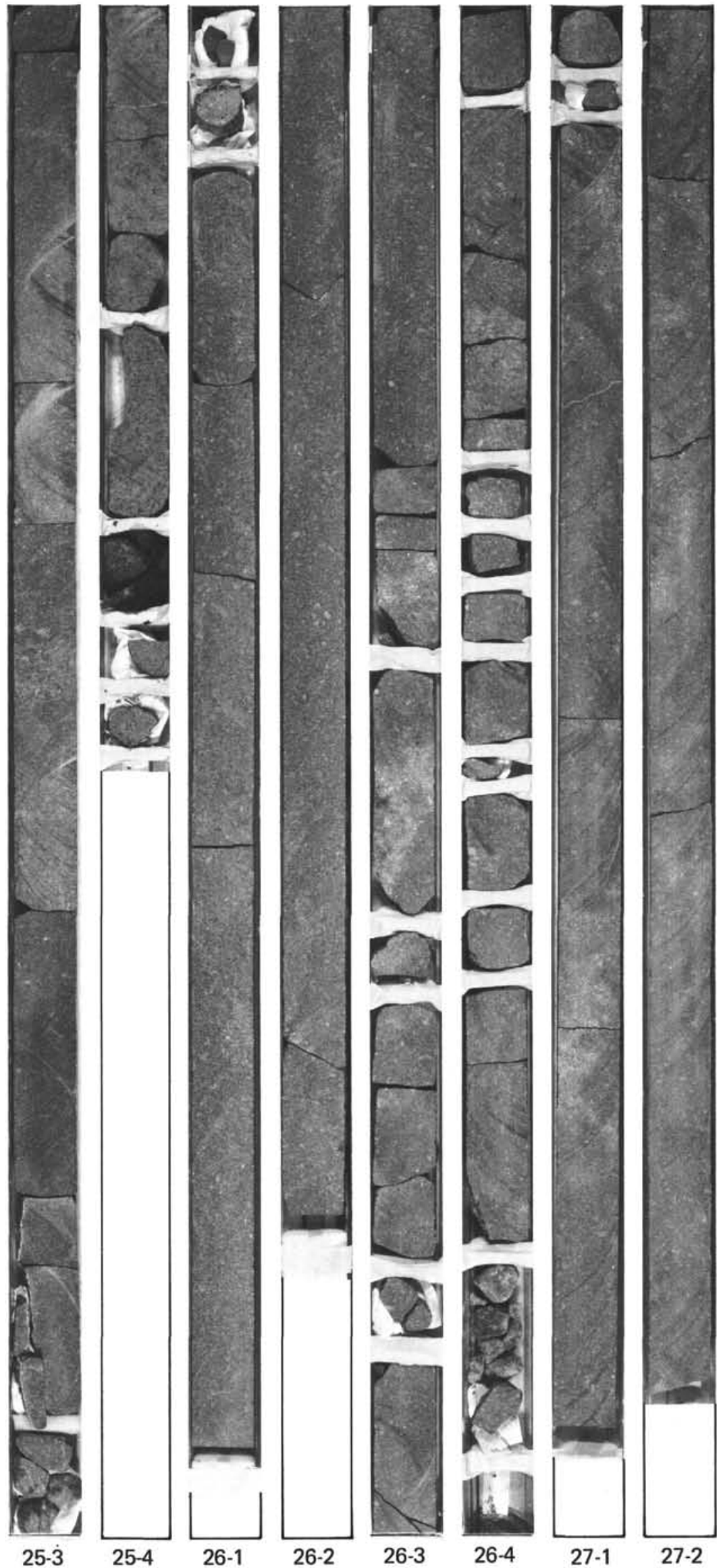
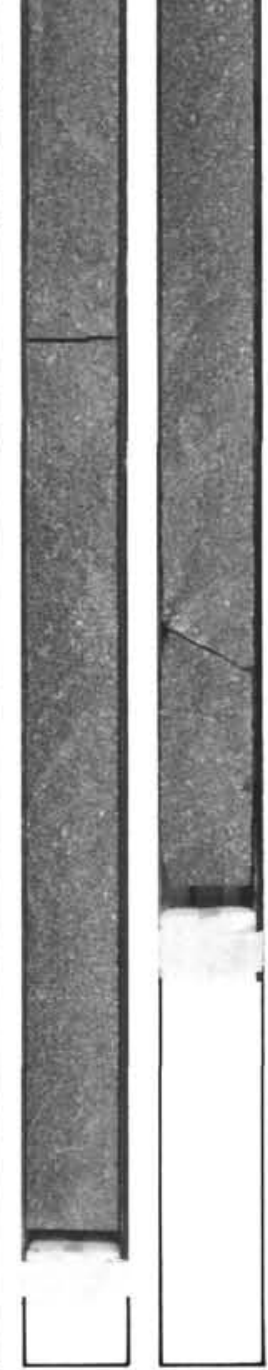

26-1
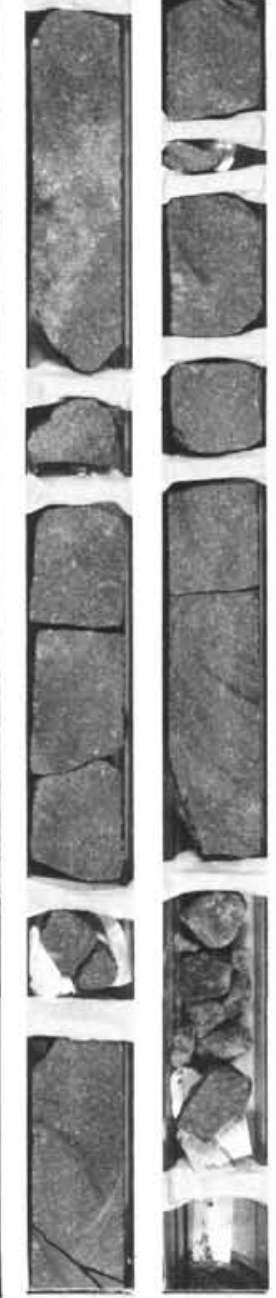

26-3

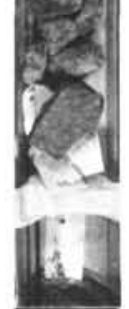

26-4

27-1
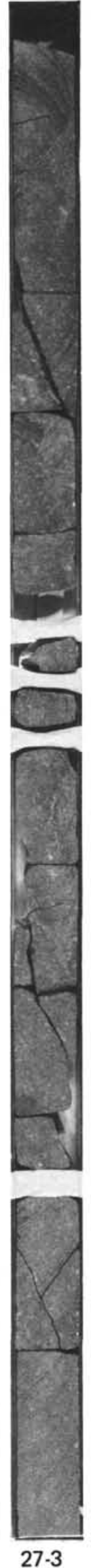
SITE 444

Hole 444A

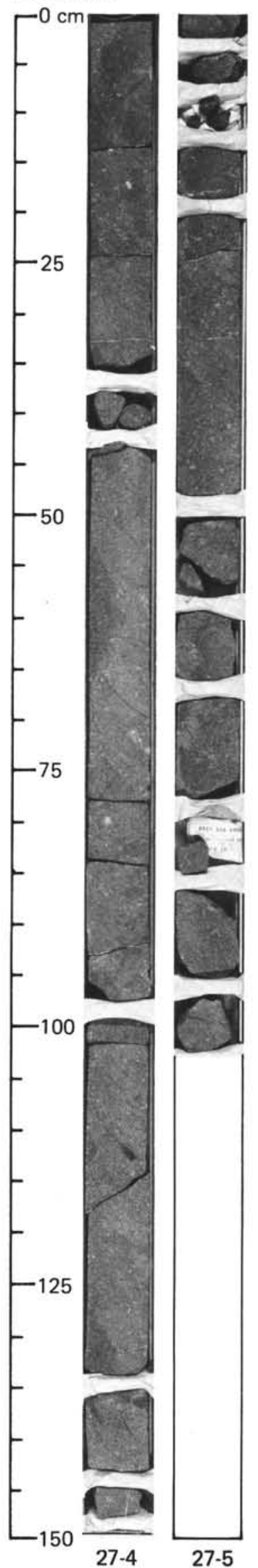

